NISTIR 6857

\title{
Persistent Organochlorine Pollutants and Elements Determined in Tissues of Rough-Toothed Dolphins (Steno bredanensis) Banked from a Mass Stranding Event
}

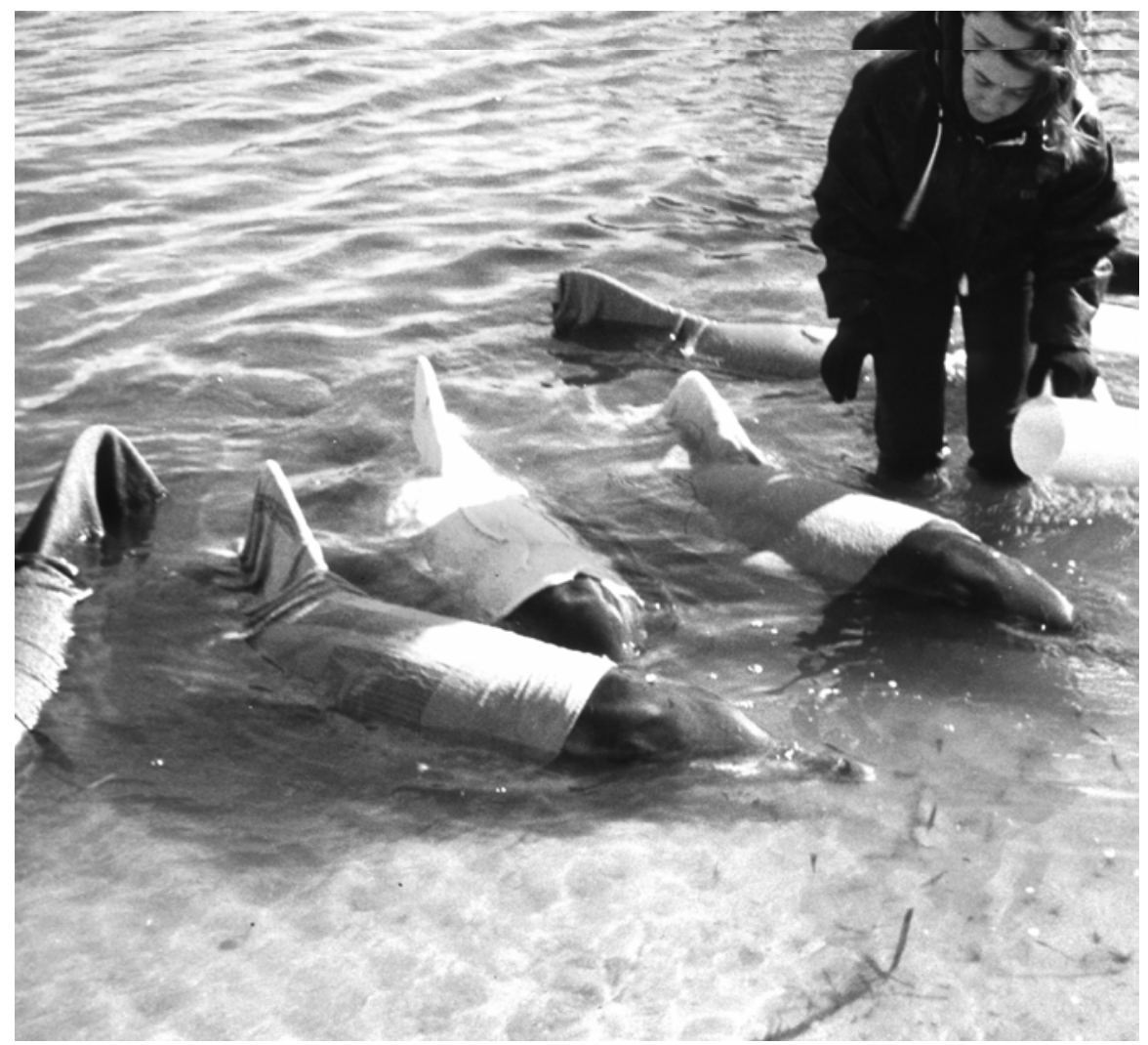

John R. Kucklick Paul R. Becker William D. J. Struntz Elizabeth A. Mackey

Barbara J. Porter Michele M. Schantz Rabia D. Oflaz

Michael S. Epstein Stephen A. Wise Teresa K. Rowles Wayne E. McFee Megan K. Stolen

March 2002

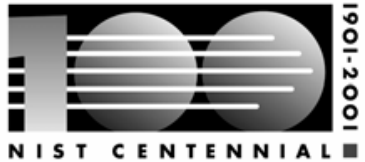


NISTIR 6857

\section{Persistent Organochlorine Pollutants and Elements Determined in Tissues of Rough-Toothed Dolphins (Steno bredadensis) Banked from a Mass Stranding Event}

John R. Kucklick Paul R. Becker

William D. J. Struntz Chemical Science and Technology Laboratory Analytical Chemistry Division

Charleston Laboratory

Elizabeth A. Mackey

Barbara J. Porter

Michele M. Schantz

Rabia D. Oflaz

Michael S. Epstein

Stephen A. Wise

Chemical Science and Technology Laboratory Analytical Chemistry Division

Teresa K. Rowles National Oceanic and Atmospheric Administration Office of Protected Resources

Wayne E. McFee National Oceanic and Atmospheric Administration National Marine Fisheries Service

Megan K. Stolen Hubbs-Sea World Research Institute

March 2002

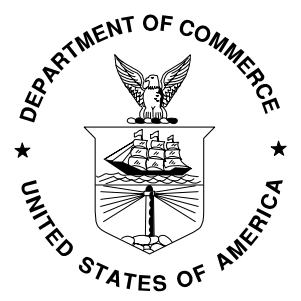

U.S. Department of Commerce Donald L. Evans, Secretary

National Institute of Standards and Technology Arden Bement, Jr., Director 


\section{PREFACE}

On December 14, 1997, personnel from the National Institute of Standards and Technology's (NIST) Charleston Laboratory and the National Oceanic and Atmospheric Administration's Center for Coastal Environmental Health and Biolmolecular Research helped respond to the stranding of 62 rough-toothed dolphins near Apalachicola, FL, Gulf of Mexico. The tissues of 15 animals were sampled for inclusion in the National Marine Mammal Tissue Bank, which is maintained by NIST as part of its National Biomonitoring Specimen Bank. The banking of marine mammal tissues from mass stranding events is conducted by NIST in support of the National Marine Fisheries Service's Marine Mammal Health and Stranding Response Program. Baseline measurements were made on the tissues of these animals for trace elements and persistent organochlorine pollutants. This report presents the results of the analyses made by NIST. 


\section{ACKNOWLEDGMENTS}

This work was made possible through support of the Marine Mammal Health and Stranding Response Program. The authors would like to express their sincere appreciation to Blair Mase, the NMFS Southeast Regional Stranding Coordinator, and the many volunteers of the Florida stranding network who responded to this mass stranding event and provided assistance in collections for the National Biomonitoring Specimen Bank. Especially important in the endeavor to necropsy the dolphins and collect samples were the efforts of Ruth Ewing of the NMFS Southeast Fisheries Science Center, Bill Fable of the NMFS Panama City Laboratory, Tim Nelson, Catherine Bray Nelson, Terri and Scott Calleson, and Misty Nabers. A special acknowledgment is given to the Florida State Park Rangers who exhibited professionalism of the highest quality, provided a secure necropsy site for those responding, and for the transport of animals from the stranding location to the necropsy site. A special thanks is also given to the NMFS Panama City Laboratory for providing space for processing and freezing samples. 


\section{DISCLAIMER}

Certain commercial equipment, instruments, or materials are identified in this report to specify in order to specify the experimental procedures adequately. Such identification is not intended to imply recommendation or endorsement by the National Institute of Standards and Technology, nor is it intended to imply that the materials or equipment are necessarily the best available for the purpose. 


\section{TABLE OF CONTENTS}

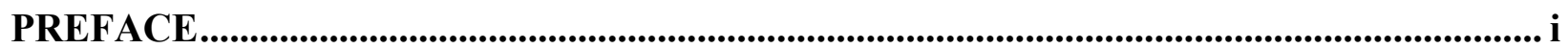

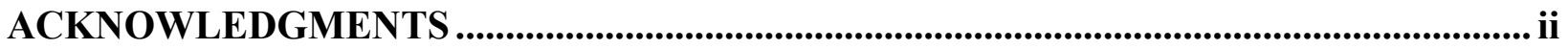

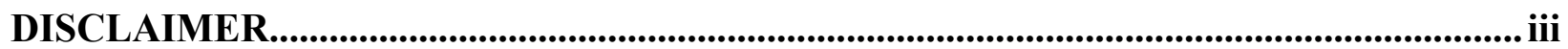

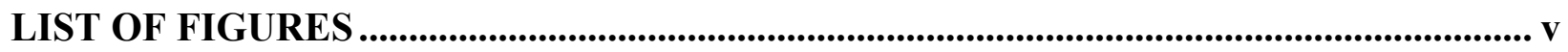

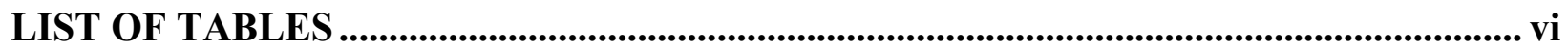

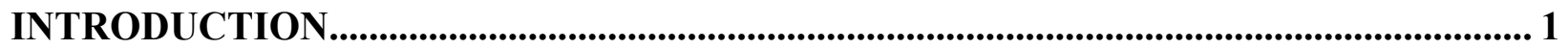

The Marine Mammal Health and Stranding Response Program and the National Marine Mammal Tissue Bank..................................................................................................................... 1

Persistent Organochlorine Pollutants and Trace Elements in Marine Mammals .................. 1

The Rough-Toothed Dolphin ........................................................................................................ 2

Objectives ...................................................................................................................................2

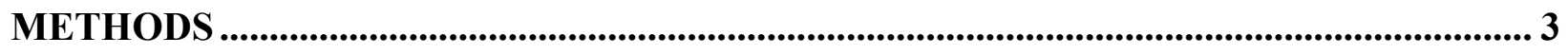

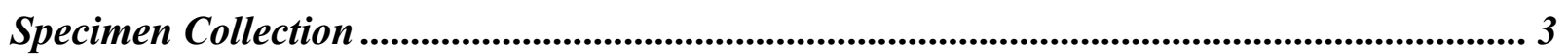

Tissue Sample Preparation .......................................................................................................... 3

Age Determination............................................................................................................................. 3

Analysis of Blubber for Persistent Organochlorine Pollutants by NIST Charleston.............. 4 Analysis of Blubber for Persistent Organochlorine Pollutants by NIST Gaithersburg ......... 6

Analysis of Liver and Kidney for Trace Elements............................................................... 7

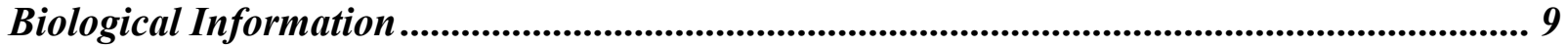

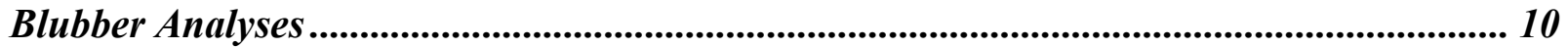

Liver and Kidney Analyses.............................................................................................. 17

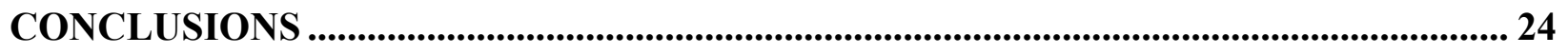

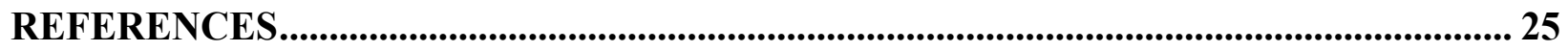

APPENDIX A: Persistent Organochlorine Compounds: Analytical Data........................... 29

APPENDIX B: Elements: Analytical Data .................................................................. 38 


\section{LIST OF FIGURES}

Figure 1: Comparison of the ratios of 4,4'-DDT to 4,4'-DDT + 4,4'-DDE (\%) in dolphin species

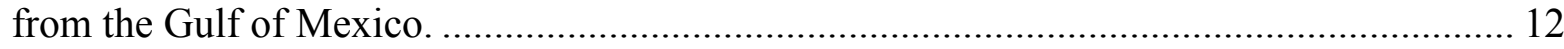

Figure 2: Age versus $\Sigma \mathrm{PCB}$ congeners (ng/g lipid mass) for female rough-toothed dolphins.... 16

Figure 3: Renal and hepatic Se concentrations $(\mathrm{mg} / \mathrm{kg})$ in rough-toothed dolphins. .................. 21

Figure 4: Hepatic (A) and renal (B) Se concentrations $(\mathrm{mg} / \mathrm{kg}$ ) as a function of rough-toothed

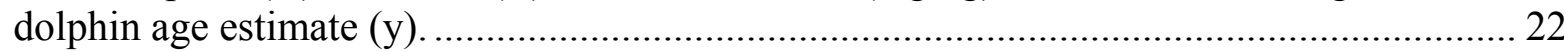

Figure 5: Hepatic (A) and renal (B) $\mathrm{Hg}$ concentrations $(\mathrm{mg} / \mathrm{kg}$ ) as a function of rough-toothed

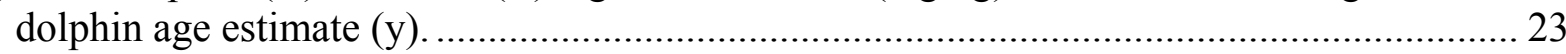

Figure 6: Hepatic Sn concentrations $(\mathrm{mg} / \mathrm{kg})$ as a function of rough-toothed dolphin age

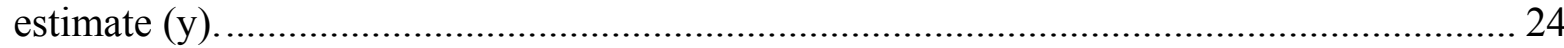

Figure A1: Chromatograms from the analysis of the PCB (A) and pesticide fractions (B) of RTDL-007 by the NIST Charleston Laboratory................................................................. 37 


\section{LIST OF TABLES}

Table 1: Individual animal and sample information ............................................................. 9

Table 2: Comparison of organochlorine concentrations (ng/g lipid mass) among dolphin species and locations. See footnote for the number of PCB congeners summed to derive $\Sigma$ PCB.... 15

Table 3: Comparison of concentration ranges ( $\mathrm{mg} / \mathrm{kg}$ wet mass) of trace elements in kidneys of rough-toothed dolphins and those of other odontocetae. .................................................. 18

Table 4: Comparison of concentration ranges ( $\mathrm{mg} / \mathrm{kg}$ of wet mass) of selected trace elements in livers of rough-toothed dolphins with ranges for other odontocetae.

Table A1: Organochlorines in SRM 1945 determined by NIST Gaithersburg and NIST Charleston $(\mathrm{n}=3$ each). Percent difference is the difference between the certified or reference (bold) values ((measured value - certified value/certified value) * 100).............. 30

Table A2: Results of paired PCB and organochlorine pesticides analyses made by NIST Gaithersburg and Charleston laboratories. Values are $\mathrm{ng} / \mathrm{g}$ wet mass.

Table A3: Concentrations (ng/g lipid mass) of PCB congeners determined in three aliquots of RTDL-004 blubber.

Table A4: Concentrations (ng/g lipid mass) of organochlorine pesticides determined in three aliquots of RTDL-004 blubber homogenate.

Table A5: Concentrations (ng/g lipid mass) of PCB congeners determined in rough-toothed dolphin blubber homogenates. Values for RTDL-001 to -006 are the average of the values determined by the Charleston and Gaithersburg NIST laboratories.

Table A6: Concentrations (ng/g lipid mass) of Organochlorine pesticides determined in roughtoothed dolphin blubber homogenates. Values for RTDL-001 to -006 are the average of the values determined by the Charleston and Gaithersburg NIST laboratories........................... 36

Table B1: Rough-toothed dolphin liver (L) and kidney (K) specimen identification codes, ratios of dry to wet mass, and \% total extractable organic content.................................................... 39

Table B2: INAA Detection limits for elements in tissue specimens. ...................................... 40

Table B3: Results of INAA and ICP-MS analyses of rough-toothed dolphin kidney and liver tissues. Values for mass fraction, uncertainties associated with counting statistics $\left(\mathrm{u}_{\mathrm{cs}}\right)$, and expanded uncertainties $(\mathrm{U} ; \mathrm{k}=2)$ are expressed as $\mathrm{mg} / \mathrm{kg}$ of wet mass.

Table B4: Results of INAA of control materials included with analyses of kidney tissues. Values for SRM 1566a Oyster Tissue are expressed in $\mathrm{mg} / \mathrm{kg}$ of dry mass and those for the QA Pilot Whale Liver Tissue Homogenate are expressed in $\mathrm{mg} / \mathrm{kg}$ of wet mass. Uncertainties represent the combined total uncertainty.

Table B5: Results of INAA of control materials included with analyses of liver tissues. Values for SRM 1566a Oyster Tissue are expressed on a dry mass basis and Whale Liver Homogenate I are expressed on a wet mass basis. Uncertainty values represent the expanded

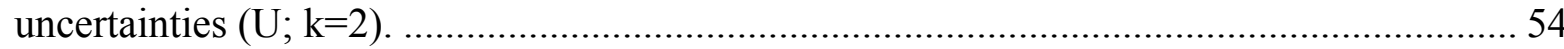

Table B6: Results of ICP-MS of Whale Liver Homogenate I expressed in $\mathrm{mg} / \mathrm{kg}$ of wet mass.

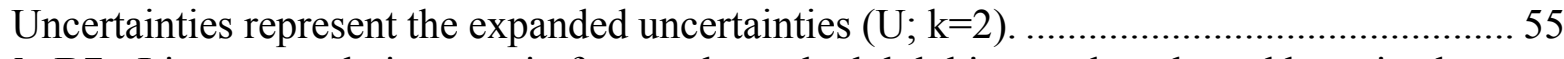

Table B7: Linear correlation matrix for rough-toothed dolphin age, length, and hepatic element concentrations. 56

Table B8: Linear correlation matrix for rough-toothed dolphin age, length, and renal element concentrations. 


\section{Persistent Organochlorine Pollutants and Elements Determined in TISSUES OF ROUGH-TOOTHED DOLPHINS (STENO BREDANENSIS) BANKED FROM A Mass STRANDing}

\section{INTRODUCTION}

\section{The Marine Mammal Health and Stranding Response Program and the National Marine Mammal Tissue Bank}

Through an agreement with the National Marine Fisheries Service (NMFS), Office of Protected Resources, NIST provides a service to the Marine Mammal Health and Stranding Response Program (MMHSRP) by maintaining the National Marine Mammal Tissue Bank (NMMTB) as part of the National Biomonitoring Specimen Bank (NBSB). NIST personnel also develop and test collection and banking protocols, and provide training to other individuals who collect specimens for the bank. One source of specimens for the NMMTB is the mass stranding of cetaceans. These events periodically occur along the coasts of the United States, particularly on the East Coast. Regional Stranding Networks consist of local and regional groups from federal, state, and local agencies; private organizations; and individuals, many of whom are volunteers. These people respond to mass strandings by providing aid to the live-stranded animals, returning the live-stranded animals to the ocean (when and where appropriate), and transporting animals to recovery facilities. They also collect data and samples from animals that die to document the age/sex population structure, life history, health condition, and other information that might be useful for scientific purposes. The stranding network members, when trained appropriately, also collect specimens for contaminant analysis and for the NMMTB.

NIST provides training, sample collection, and banking of marine mammal specimens for the MMHSRP and NMMTB. Additionally, NIST provides retrospective and baseline analysis of organic and inorganic contaminants on selected marine mammal specimens from the bank as part of the National Marine Analytical Quality Assurance Program. Additional details on NIST's role in the NMMTB, MMHSRP, and the National Marine Analytical Quality Assurance Program are provided in Becker et al. (1999).

\section{Persistent Organochlorine Pollutants and Trace Elements in Marine Mammals}

Contamination of food webs by anthropogenic persistent organochlorine pollutants (POPs), such as polychlorinated biphenyls (PCBs), DDT, toxaphene, and chlordane, was first documented by Jensen (1966) and of marine mammals by Holden and Mardsen (1967). Subsequently, researchers have determined that the release of POPs during their manufacture, storage, and use has resulted in global contamination, particularly of the marine environment (e.g., Tanabe, 1985; Muir et al., 1999). Due to their persistence and highly lipophilic nature, many POPs bioaccumulate and biomagnify in the food chain (e.g., Tanabe, 1985; Muir et al., 1988). POP residues have been detected in all levels of aquatic biota ranging from phytoplankton to marine mammals (Muir et al., 1999). Biological effects of these compounds on mammals include hepatocellular carcinoma; reproductive, endocrine, and developmental toxicity; immunotoxicity, and wasting syndrome (Safe, 1990). Toothed whales (odontocetes) are particularly susceptible 
to bioaccumulation and the effects of POPs due to many factors including their relatively high trophic position, long life spans, limited metabolic capability to degrade chemical contaminants, and reproductive strategies (Tanabe et al., 1994).

For many marine mammal species, the ranges of normal elemental concentrations are not known. Levels of some metals in marine mammal tissues are often higher than concentrations found in terrestrial mammals (i.e., mercury and cadmium) and there are often marked differences in element levels among different marine mammal species. There also may be differences among animals of the same species but from different locations. Concentrations for selected elements in various tissues have been reported for common dolphins (Delphinus delphinus), harbor porpoise (Phocoena phocoena), pilot whale (Globicephala melas), beaked whales (Ziphiidae) and many other species of odontocetes or "toothed whales" (e.g., Mackey et al., 1996; Law et al., 1997), but there are no trace element data for rough-toothed dolphins (Steno bredanensis).

\section{The Rough-Toothed Dolphin}

Rough-toothed dolphins are pelagic odontocetes that are widely distributed in tropical and warm temperate oceans around the world. Most information on this species has come from populations in the eastern Pacific Ocean (Miyazaki and Perrin, 1994), with little available information on the populations inhabiting the Gulf of Mexico or western Atlantic Ocean (Blaylock et al., 1995). Growth occurs most rapidly during the first five years of life. Both sexes attain maximum lengths of approximately $280 \mathrm{~cm}$ with males reaching sexual maturity at approximately $225 \mathrm{~cm}$ or 14 years of age, and females at $210 \mathrm{~cm}$ or 10 years of age (Miyazaki and Perrin, 1994). Morphological features that distinguish this species from other members of the delphinid family (e.g., bottlenose dolphin (Tursiops truncatus)) include the lack of visible demarcation between beak and melon, and the rugose tooth surface from which its common name is derived. Coloration varies geographically, but animals are generally dark gray dorsally with variable pinkish and white markings ventrally (Miyazaki and Perrin, 1994). Rough-toothed dolphins are social animals, typically found in small groups ranging from 10 to 20 individuals with larger groups reported (Leatherwood et al., 1982; Miyazaki and Perrin, 1994). Their diet mainly consists of pelagic fish and squid (Layne, 1965; Clarke, 1986; Barros to McFee, personal communication).

\section{Objectives}

The authors are aware of only two previous publications describing organic contaminants in this species- Marsili and Focardi $(1997, \mathrm{n}=1)$ and O'Shea et al. $(1980, \mathrm{n}=7)$. The objective of this report is to document POP and inorganic constituents in tissues of rough-toothed dolphins from the Gulf of Mexico. Prior to this report there were no data on POPs or inorganic constituents in this species from this region. This report contains both organic and inorganic data, generated by NIST, for dissemination to sponsors and user groups. These data will help to establish baseline levels of POPs and both essential and potentially toxic elements in the tissues of this species. 


\section{METHODS}

\section{Specimen Collection}

On December 15, 1997, 62 rough-toothed dolphins stranded on the Gulf Coast of Florida near Apalachicola at St. Joseph State Park $\left(29^{\circ} 45.2^{\prime} \mathrm{N}, 85^{\circ} 25^{\prime} \mathrm{W}\right)$. All the animals were pushed back out to sea. However, 34 animals restranded and of those, 17 died on site, 1 swam away, and 16 were sent to rehabilitation facilities, of which 4 were released. Fifteen of the restranded animals that died on the beach were necropsied and sampled for the NMMTB. In addition to the tissues sampled for the NMMTB (blubber, kidney, and liver) and real-time contaminant monitoring (blubber, melon, and muscle, NOAA/NMFS/Northwest Fisheries Science Center (NWFSC)), samples were provided to the Armed Forces Institute of Pathology for histological and pathological analyses. Teeth were also removed from the animals for age determination (Table 1). Samples for the NMMTB were collected and processed using standard NIST protocols (Becker et al., 1999). These protocols consist of the removal of tissue specimens from each animal using standard procedures and equipment designed to minimize the contamination of the tissues during removal and handling. Because of the rapid deterioration of tissues following death, it was decided that only animals that strand alive and die of natural causes or are euthanized, or animals that are considered "freshly dead," are sampled.

Materials that contacted the specimens were limited to Teflon and titanium. The tissue samples (blubber, kidney and liver) were excised from the animals using titanium knives, placed in Teflon bags, and transported on ice to the NOAA/NMFS Panama City Laboratory. At the laboratory, each specimen was divided into Samples A and B (approximately $150 \mathrm{~g}$, each) according to the NMMTB protocols (Becker et al., 1999), placed in pre-cleaned Teflon sample jars, frozen, and express shipped to the NBSB, NIST Gaithersburg, MD in liquid nitrogen vapor shippers. Upon arrival at NIST, samples were immediately placed in liquid nitrogen-vapor cooled $\left(-150^{\circ} \mathrm{C}\right)$ freezers.

\section{Tissue Sample Preparation}

Each tissue specimen to be analyzed (approximately $150 \mathrm{~g}$, each) was homogenized using a cryogenic procedure designed to reduce the likelihood of changes in sample composition due to thawing and refreezing (Zeisler et al., 1983). Subsamples of the tissue homogenate, a frozen (non freeze-dried) powder, were transferred to Teflon jars $(10 \mathrm{~mL})$ for storage $\left(\right.$ at $\left.-150{ }^{\circ} \mathrm{C}\right)$ until analyses were performed. Portions used for instrumental neutron activation analysis (INAA) were lyophilized prior to analysis.

\section{Age Determination}

Teeth were extracted from the jaws during necropsy or after maceration in the lab. Teeth were sectioned longitudinally to a thickness of $2 \mathrm{~mm}$ using a low-speed saw (Isomet 11-1180, Lake Bluff, IL). Sections were then placed in 10\% neutral buffered formalin for approximately $24 \mathrm{~h}$. Samples were removed and rinsed in running tap water for approximately $3 \mathrm{~h}$ and then soaked in tap water for at least $24 \mathrm{~h}$. Sections were placed in approximately $80 \mathrm{~mL}$ of a decalcifying agent. 
Decalcification was prolonged (relative to Tursiops teeth) and took approximately $6 \mathrm{~h}$ to $16 \mathrm{~h}$ for completion. Decalcified sections were rinsed in running water for $6 \mathrm{~h}$ and then soaked in tap water for at least $24 \mathrm{~h}$.

Teeth were serially sectioned using a sledge-type microtome (American Optical Co., Southbridge, MA) with a freezing attachment. Each $2 \mathrm{~mm}$ section was further sectioned to 25 $\mu \mathrm{m}$ then soaked in tap water for at least $1 \mathrm{~h}$ to remove any additional acid. Thin sections were stained in Mayer's hematoxylin for $75 \mathrm{~min}$, rinsed in tap water for $1 \mathrm{~min}$, blued in $0.5 \%$ ammonium hydroxide, and then rinsed again. Teeth were placed in 50\% glycerin for 30 min and then placed in $100 \%$ glycerin for $24 \mathrm{~h}$ to complete the exchange of water to glycerin. Sections were mounted on slides in 100\% glycerin. This method has been used successfully for other small delphinids (Perrin and Myrick, 1980; Myrick et al., 1983).

Sections were examined under $10 \mathrm{X}$ to $60 \mathrm{X}$ magnification using a stereoscopic microscope (Nikon, Tokyo, Japan). Growth layers were generally read using guidelines developed for Tursiops by Hohn et al. (1989). Each growth layer group (GLG) consisted of a dark and light staining layer. Sections were read three times in the blind and the average reading was considered the final estimate. In a few cases, when readings were several layers apart, a fourth reading was taken and a subjective decision was made for the final estimation. Several of the teeth had extensive damage caused by extraction and could only provide minimum age estimates. For quality assurance purposes, the process was repeated using a second and sometimes third tooth (when available). In such cases, all sections were evaluated and readings were made from the best-mounted sections. This procedure was necessary for most of the older animals. Ages were estimated to the last fully formed GLG except in younger animals. Animals with less than 8 GLGs were read to the nearest 0.5 GLG and animals $<1$ GLG were aged to the nearest 0.25 GLG. It has been established with other small delphinids that one GLG corresponds to $1 \mathrm{y}$ of life. This was assumed to be the case for rough-toothed dolphins, although this relationship has not been verified directly.

\section{Analysis of Blubber for Persistent Organochlorine Pollutants by NIST Charleston}

Cryo-homogenized blubber samples were shipped from the NMMTB in Gaithersburg, MD to the NIST Charleston Laboratory in a liquid-nitrogen-vapor shipper. Upon arrival specimens were stored at $-80{ }^{\circ} \mathrm{C}$ until required for analysis. The Teflon jar containing the sample was removed from the $-80{ }^{\circ} \mathrm{C}$ freezer and immediately placed in a small Dewar flask containing approximately $100 \mathrm{~mL}$ of liquid nitrogen. Between $0.792 \mathrm{~g}$ and $1.21 \mathrm{~g}$ of sample was removed from the jar using a clean metal spatula that had been immersed in liquid nitrogen to prevent the frozen sample from adhering to the spatula. The frozen sample was placed in a clean $150 \mathrm{~mL}$ beaker and weighed to the nearest $0.001 \mathrm{~g}$. A small Styrofoam block was placed on the balance pan under the beaker to provide insulation and prevent balance drift. The sample was mixed with 30 g of sodium sulfate $\left(\mathrm{Na}_{2} \mathrm{SO}_{4}\right.$; combusted at $700{ }^{\circ} \mathrm{C}$ for $24 \mathrm{~h}$, then cooled in a desiccator prior to use). The mixture was then transferred to a $33 \mathrm{~mL}$ pressurized fluid extractor cell (PFE; Dionex, Salt Lake City, UT) to which $10 \mathrm{~g}$ of $\mathrm{Na}_{2} \mathrm{SO}_{4}$ had been previously added. A small volume (approximately $1 \mathrm{~mL}$ ) of dichloromethane $\left(\mathrm{CH}_{2} \mathrm{Cl}_{2}\right)$ was added to rinse the beaker, and then transferred to the PFE cell. For quality assurance purposes, RTDL-004 was analyzed independently three times, and two blanks and two aliquots of NIST SRM 1945 Organics in 
Whale Blubber were prepared and analyzed. Each blank consisted of approximately $45 \mathrm{~g}$ of $\mathrm{Na}_{2} \mathrm{SO}_{4}$ in a PFE cell. The samples of SRM 1945 were prepared in the same manner as the dolphin blubber samples. A mixed internal standard solution containing 4,4'-DDT- $d_{8}, 4,4$ 'DDE- $d_{8}, 4,4$ '-DDD- $d_{8}$, endosulfan I- $d_{4}$, PCB 103 , and PCB 198 was then added to the PFE cells, by weighing (to the nearest $0.00001 \mathrm{~g}$ ) approximately $1 \mathrm{~mL}$ of the solution.

Six calibration solutions were prepared by weighing (to the nearest $0.00001 \mathrm{~g}$ ) portions of SRMs 2261 Chlorinated Pesticides in Hexane, 2262 Chlorinated Biphenyl Congeners in 2,2,4trimethylpentane, 2274 PCB Congener Solution-II in Isooctane and 2275 Chlorinated Pesticide Solution-II in Isooctane into weighed portions of isooctane. The calibration curve ranged from approximately $5 \mathrm{ng}$ to $1000 \mathrm{ng}$ added to the PFE cell. Approximately $1 \mathrm{~mL}$ of the appropriate mixed calibration solution was weighed (to the nearest $0.00001 \mathrm{~g}$ ) in an HPLC syringe, then added on top of the $\mathrm{Na}_{2} \mathrm{SO}_{4}$. The mixed internal standard solution was then added to each PFE vial, by weighing (to the nearest $0.00001 \mathrm{~g}$ ), approximately $1 \mathrm{~mL}$ of the solution.

The samples were extracted with $\mathrm{CH}_{2} \mathrm{Cl}_{2}$ using PFE. The conditions were as follows: the cell temperature was $100{ }^{\circ} \mathrm{C}$, equilibration $5 \mathrm{~min}$, static time $5 \mathrm{~min}$, cell pressure was $6.89 \mathrm{MPa}$ and there were three cycles (one-third of the solvent each time). The sample extracts were then reduced to between $0.5 \mathrm{~mL}$ to $1 \mathrm{~mL}$ by evaporation in a stream of purified nitrogen using a Turbovap II (Zymark, Hopkinton, MA). High-molecular-mass compounds were removed by size exclusion chromatography (SEC) using a $600 \mathrm{~mm}$ x $25 \mathrm{~mm}(10 \mu \mathrm{m}$ particle size with $100 \AA$ diameter pores) PLGel column (Polymer Labs, Amherst, CA) as described in Kucklick et al. (2001). The extract was then fractionated using a semi-preparative aminopropylsilane column ( $\mu$ Bondapak $\mathrm{NH}_{2}$, Waters) into relatively lower- and higher-polarity fractions ( $\mathrm{F} 1$ and $\mathrm{F} 2$, respectively). $\mathrm{F} 1$ consisted of $50 \mathrm{~mL}$ of hexane, while $\mathrm{F} 2$ consisted of $60 \mathrm{~mL}$ of $25 \% \mathrm{CH}_{2} \mathrm{Cl}_{2}$ in hexane. Target compounds contained in F1 included PCBs, heptachlor, oxychlordane, 2,4'DDE, 4,4'-DDE, 2,4'-DDT, hexachlorobenzene (HCB), and mirex. Target analytes in F2 included 4,4'-DDT, cis- and trans-chlordane, cis- and trans-nonachlor, $\alpha-, \beta-$, and $\gamma$ hexachlorocyclohexane $(\mathrm{HCH})$, heptachlor epoxide, $2,4^{\prime}$ - and 4,4'-DDD, and dieldrin.

Organochlorine compounds were determined by injecting each sample twice into a gas chromatograph (GC) with dual micro-electron capture detectors (ECD) (Hewlett Packard 6890, Palo Alto, CA). Organochlorines in F1 and F2 from the aminopropylsilane column were separated using a $60 \mathrm{~m} \mathrm{5 \%}$ phenyl methylpolysiloxane column (DB-5, J\&W Scientific, Folsom, CA) with $0.25 \mathrm{~mm}$ internal diameter and a $0.25 \mu \mathrm{m}$ film thickness and a $60 \mathrm{~m}$ DB-XLB (proprietary phase, J\&W Scientific) with $0.25 \mathrm{~mm}$ interior diameter and a $0.25 \mu \mathrm{m}$ film thickness. The instrument was configured by installing a $5 \mathrm{~m} \times 0.25 \mathrm{~mm}$ retention gap to the inlet, then attaching a glass $\mathrm{Y}$ connector to the free end. The columns were connected to the $\mathrm{Y}$ splitter, then to the ECDs. The injector and detector temperatures were $220{ }^{\circ} \mathrm{C}$ and $325{ }^{\circ} \mathrm{C}$, respectively; the carrier and makeup gasses were $\mathrm{H}_{2}$ (constant velocity of $\left.30 \mathrm{~cm} / \mathrm{s}\right)$ and $\mathrm{N}_{2}(60$ $\mathrm{mL} / \mathrm{min})$, respectively. Samples were injected into the GC ( $2 \mu \mathrm{L}$, splitless injection), and the oven was programmed from $90{ }^{\circ} \mathrm{C}$ initially ( 1 min hold) to $170{ }^{\circ} \mathrm{C}$ at $25{ }^{\circ} \mathrm{C} / \mathrm{min}$, then $1{ }^{\circ} \mathrm{C} / \mathrm{min}$ to $260{ }^{\circ} \mathrm{C}$, then ramped to $300{ }^{\circ} \mathrm{C}$ at $15{ }^{\circ} \mathrm{C} / \mathrm{min}(10 \mathrm{~min}$ hold, $107 \mathrm{~min}$ total run time). The amount of each compound in the unknown was calculated using the mass of internal standard added and the slope and intercept of either the entire six-point calibration curve generated from the response of the calibrants or those generated from the three calibrants which bracketed the 
concentration. Different internal standards were used to quantify target analytes to avoid suspected interferences and to maximize repeatability and reproducibility. PCB 103 was used to quantify all F1 analytes other than 4,4'-DDE, which was quantified using 4,4'-DDE- $d_{8}$. All F2 analytes were quantified using endosulfan I- $d_{4}$. Analyses of most F1 target analytes were made with the DB-XLB column (Figure A1-a), as it gave baseline resolution on the majority of PCBs, and using PCB 103 as the internal standard. PCBs 87 and 101 were quantified with the DB-5 column, using PCB 103 as the internal standard, because of coelution problems on the DB-XLB column (Kucklick et al., 2001). All F2 target analytes were quantified using GC-ECD with the DB-5 column and a splitless injection (Figure A1-b). Detection limits were calculated as three times the concentration of a given compound in the mean blank, which gave more conservative detection limits than using the mean blank plus three standard deviations. The total non-volatile solvent extractable material was measured on subsamples (50\% of total) taken from the original extracts by first reducing the solvent volume from the extraction with the Turbovap, then allowing the remaining solvent to evaporate at room temperature. The extracts were repeatedly weighed until a stable mass was achieved. The ratio of the residue to the wet mass extracted represents the fraction of the total non-volatile solvent extractable material.

\section{Analysis of Blubber for Persistent Organochlorine Pollutants by NIST Gaithersburg}

The NIST Gaithersburg laboratory also analyzed six rough-toothed dolphin blubber samples: RTDL-001 to RTDL-006. The sample extraction and clean up procedures were similar to those detailed above. Briefly, the blubber homogenates were mixed with $\mathrm{Na}_{2} \mathrm{SO}_{4}$ then added to PFE cells. The cells were spiked with an internal standard mixture containing PCB 103, 198, and perdeuterated 4,4'-DDT. The sample and calibrants were extracted and high-molecular-weight materials were removed from the extracts using SEC. The chlorinated extract was reduced in volume then further isolated using a silica solid-phase extraction column (plus size, Waters Corporation, Milford, MA) that was precleaned using $15 \mathrm{~mL}$ of $10 \%$ dichloromethane in hexane. The fraction of interest was eluted also with $10 \%$ volume fraction of $\mathrm{CH}_{2} \mathrm{Cl}_{2}$ in hexane. The eluant was concentrated to approximately $0.5 \mathrm{~mL}$ for analysis.

The concentrated samples were analyzed using gas chromatography-mass spectrometry (GC-MS, Hewlett Packard 6890/5973). A $0.25 \mathrm{~mm}$ x $30 \mathrm{~m}$ fused-silica capillary column containing 5\% phenyl-substituted methylpolysiloxane phase (HP-5ms, Hewlett Packard), $0.25 \mu \mathrm{m}$ film thickness was used. The column was held isothermally $\left(60{ }^{\circ} \mathrm{C}\right)$ for $1 \mathrm{~min}$, temperature programmed at $45^{\circ} \mathrm{C}$ per min to $180{ }^{\circ} \mathrm{C}$ for $30 \mathrm{~min}$, and then temperature programmed at $2{ }^{\circ} \mathrm{C}$ per min to $250{ }^{\circ} \mathrm{C}$ where it was held isothermally for $15 \mathrm{~min}$. All injections were $2 \mu \mathrm{L}$ in a pulsed splitless mode. Helium was used as a carrier gas at a constant flow rate of $1 \mathrm{~mL}$ per min. The MS transfer line was held at $280^{\circ} \mathrm{C}$. The major ions included 222, 255.95, 289.90, 323.9, $359.85,393.80,425.75,463.75,497.70$ for the PCBs and 284, 181, 389, 353, 246, 371, 409, 235, 243, 195, 263, 272 for the pesticides. Seven-point calibration response curves for the analytes relative to the internal standards were determined by processing gravimetrically-diluted PCB and pesticide calibrant solutions. The percent nonvolatile extractable material (mainly lipid) was determined for each sample after extraction. The extract was evaporatively concentrated to approximately $20 \mathrm{~mL}$ (mass known), and an aliquot of $90 \mu \mathrm{L}$ (mass known) was placed on an aluminum pan. The extract on the pan was air dried, and the mass of the dried extract was noted. 
The ratio of the residue to the wet mass extracted represents the fraction of the total non-volatile solvent extractable material.

\section{Analysis of Liver and Kidney for Trace Elements}

Instrumental Neutron Activation Analysis (INAA) for 35 Elements in Livers and Kidneys: Each sub-sample selected for INAA was freeze-dried at $1 \mathrm{~Pa},-20{ }^{\circ} \mathrm{C}$ shelf temperature and -50 ${ }^{\circ} \mathrm{C}$ condenser temperature, for $5 \mathrm{~d}$. Five of the 15 tissues were subjected to additional drying because the tissues did not appear to be dry after $5 \mathrm{~d}$. Subsequent drying, for an additional $5 \mathrm{~d}$, did not result in significant changes in the values for the ratios of dry to wet mass for these tissues. Determination of total extractable organic material showed that those kidney tissues that did not appear to be dry contained greater amounts of lipid than the other tissues. The wet appearance of these sub-samples (from animals identified as RTDL-003, RTDL-005, RTDL-007, RTDL-008, and RTDL-013) was probably due to a relatively high lipid content rather than to insufficient drying. The ratios of dry mass to wet mass, or conversion factors (C.F.), for the 15 kidney and 15 liver tissue samples are listed in Table B1 (in Appendix B) together with the animal and tissue identification codes.

Two disks, approximately $200 \mathrm{mg}$ each, were formed from each of the dried, powdered subsamples using a commercially available stainless steel die and hydraulic press. Two disks were also formed from SRM 1566a Oyster Tissue, and one from a pilot whale liver tissue homogenate (Whale Liver Homogenate I) that is used for quality assurance in the analysis of marine mammal tissues (Wise et al., 1993, Becker et al., 1999). The mass of each disk was recorded and all were packaged in acid-washed linear polyethylene (LPE) film in preparation for irradiation. Disks were also formed from standards consisting of filter papers containing known amounts of each element.

Analyses of short-lived products of neutron irradiation were performed sequentially over the course of several days. Each sample or aliquot of SRM was irradiated, together with one of the standards, for $120 \mathrm{~s}$ in the NIST reactor pneumatic tube irradiation facility, RT-4, at reactor power of $20 \mathrm{MW}$. After the irradiation, each sample, control, and standard was repackaged in clean LPE film for counting. Each sample was placed at a distance of $18 \mathrm{~cm}$ from a germanium detector, and gamma rays were collected for $300 \mathrm{~s}$ after a decay time of approximately $120 \mathrm{~s}$ for determination of $\mathrm{Mg}, \mathrm{Cl}, \mathrm{Ca}, \mathrm{V}, \mathrm{Cu}, \mathrm{Br}$, and $\mathrm{I}$. Gamma rays were collected again, after 2 to $3 \mathrm{~h}$ of decay, for $20 \mathrm{~min}$ at a distance of $8 \mathrm{~cm}$ for the determination of $\mathrm{Na}, \mathrm{K}$, and $\mathrm{Mn}$.

Analyses of intermediate-lived and long-lived products of neutron irradiation were performed after the analyses of short-lived products. Samples and standards were packaged individually in bags formed from LPE film and placed together in a polyethylene irradiation vessel or rabbit. For the assay of intermediate- and long-lived nuclides, each rabbit was irradiated in a pneumatic rabbit tube irradiation facility at a reactor power of $20 \mathrm{MW}$ for $16 \mathrm{~h}$. After a decay time of approximately $6 \mathrm{~d}$, gamma rays from intermediate-lived nuclides (As, Mo, Cd, La, Sm, and Au) were collected for $2 \mathrm{~h}$ from samples positioned $15 \mathrm{~cm}$ from an intrinsic germanium detector. After decay times of 4 to 8 weeks, gamma rays from long-lived nuclides ( $\mathrm{Sc}, \mathrm{Fe}, \mathrm{Co}, \mathrm{Zn}, \mathrm{Se}, \mathrm{Rb}$, $\mathrm{Sr}, \mathrm{Ag}, \mathrm{Sn}, \mathrm{Sb}, \mathrm{Cs}, \mathrm{Ba}, \mathrm{Ce}, \mathrm{Eu}, \mathrm{Tb}, \mathrm{Hf}, \mathrm{Ta}, \mathrm{Th}$, and $\mathrm{U}$ ) were collected for $8 \mathrm{~h}$ from samples positioned approximately $5 \mathrm{~cm}$ from the same detector. 
Spectral reduction and data analysis were accomplished using a $\mu$ VAX 3400 computer with Nuclear Data peak search and activation analysis software. Quantitative evaluation was done by the comparator method using all standards from the individual irradiations. Nuclear Data software was used to calculate "standard constants" (the ratio of the amount of activity of a given nuclide that was present immediately after irradiation to the mass of the element, $A_{o} / g$ ) and these constants were used to determine element concentrations of the samples.

Mass fractions of the following elements were at or below the INAA detection limits in these tissues: Sc, V, Sr, Mo, Cd, Sn, Sb, I, Ba, La, Ce, Sm, Eu, Tb, Hf, Ta, Au, Th, and U. INAA detection limits are listed in Table B2 in Appendix B. All results from analysis of individual portions are listed in Table B3 in Appendix B and discussed below.

Sources of uncertainty for this analysis included uncertainty of counting statistics, uncertainty in the element content of the standards, uncertainty in dry mass of materials, and any differences between samples and standards in irradiation and counting geometries. Analysis of portions of SRM 1566a and Whale Liver Homogenate (I) were included for the purpose of quality assurance. Results of analysis of these control materials are shown in Tables B4 and B5 in Appendix B. INAA values agree with the certified or literature values within the total uncertainties listed.

ICP-MS Analysis of $\mathrm{Cd}, \mathrm{Hg}, \mathrm{Pb}, \mathrm{Sb}, \mathrm{Tl}, \mathrm{Th}, \mathrm{Mn}, \mathrm{Sn}, \mathrm{Cu}, \mathrm{Ag}$ and $\mathrm{Zn}$ in Liver and Kidney Samples: Frozen sub-samples of dolphin tissues weighing between $0.3 \mathrm{~g}$ and $0.7 \mathrm{~g}$ were transferred to tared $100 \mathrm{~mL}$ PFA-Teflon containers using a ceramic spatula. The spatula was cleaned with high-purity water, wiped with a metal-free cloth, and chilled before use. The weighing process was performed rapidly to prevent the defrosting and gelling of the tissue samples. Each container of dolphin tissue was sampled at least two times so that duplicate sample preparations could be made. An acid mixture containing $4 \mathrm{~mL}$ of $\mathrm{HNO}_{3}$ and $2 \mathrm{~mL}$ of $\mathrm{HClO}_{4}$ was added to each container, which was then sealed. The samples were dissolved by microwave digestion (Milestone MLS-2100, Monroe, CT). After digestion, the sample containers were cooled, and the samples transferred to $100-\mathrm{mL}$ low-density-polyethylene bottles and diluted to a final volume of approximately $100 \mathrm{~mL}$ with high-purity water containing $1 \%$ $\mathrm{K}_{2} \mathrm{Cr}_{2} \mathrm{O}_{7}$. The mass and density of each final solution was used to calculate the analyte concentration.

The above elements were determined by inductively coupled plasma mass spectrometry (ICPMS) using a Perkin Elmer (Boston, MA) Elan 5000 ICP-MS in the TotalQuant II mode and external standards. As a quality assurance check on the ICP-MS measurements, $\mathrm{Pb}$ was determined on selected subsamples by electrothermal atomic absorption spectrometry (ETAAS) and $\mathrm{Hg}$ was determined by cold-vapor atomic absorption spectroscopy (CVAAS). All results from analysis of individual portions are listed in Table B3 in Appendix B and discussed below. Analysis of Whale Liver Homogenate (I) was included for the purpose of quality control and results are listed in Table B6, Appendix B. Mass fractions of Sb, Tl, and Th were $<0.05 \mathrm{mg} / \mathrm{kg}$. 


\section{RESULTS AND DISCUSSION}

\section{Biological Information}

Total length $(\mathrm{cm})$ and animal gender are presented in Table 1. Of the 15 animals, 6 were male and 9 were female; 3 females were pregnant and all fetuses were female. The most common pathological conditions found during the necropsies were ectopic or displaced spleen (9 of 15 animals), pneumonia (8 animals), and fibroid kidneys (7 animals).

Table 1: Individual animal and sample information

\begin{tabular}{lccccc}
\hline NBSB Number & $\begin{array}{c}\text { Age } \\
\text { (years) }\end{array}$ & $\begin{array}{c}\text { Length } \\
\text { (cm) }\end{array}$ & $\begin{array}{c}\text { Lactating (L) } \\
\text { or with fetus (F) }\end{array}$ & $\begin{array}{c}\text { Blubber Lipid } \\
\text { (percent) }\end{array}$ & $\begin{array}{c}\text { Kidney Lipid } \\
\text { (percent) }\end{array}$ \\
\hline Male & & & & & \\
RTDL-012 & 0.5 & 136 & -- & 54.9 & 5.9 \\
RTDL-014 & 2.5 & 185 & -- & 60.0 & 7.19 \\
RTDL-004 & 3 & 199 & -- & $55.8 *$ & 5.92 \\
RTDL-006 & 4.5 & 207 & -- & 73.3 & 6.13 \\
RTDL-002 & 10 & 229 & -- & 44.4 & 6.72 \\
RTDL-005 & na** & 235 & -- & 42.8 & 20.5 \\
& & & & & \\
Female & & & & & \\
RTDL-001 & 0.8 & 183 & -- & 66.3 & 5.25 \\
RTDL-011 & 3.5 & 202 & -- & 58.1 & 9.3 \\
RTDL-015 & 4 & 177 & -- & 45.4 & 6.27 \\
RTDL-010 & 10 & 209 & -- & 54.2 & 12.2 \\
RTDL-009 & 7.5 & 228 & -- & 61.1 & 29.8 \\
RTDL-008 & 22 & 221 & L & 49.1 & 15.8 \\
RTDL-003 & 25 & 235 & F & 38.0 & 45.2 \\
RTDL-013 & 42 & 253 & F & 50.4 & 32.4 \\
RTDL-007 & na & 241 & F & 41.1 &
\end{tabular}

*Average of three measurements

**na; not available

The mean lipid (total non-volatile solvent extractable material) content of the female roughtoothed dolphin blubber samples was $51.5 \%$ with a range from $38.0 \%$ to $66.3 \%$ and in males was $55.1 \%$ with a range from $42.8 \%$ to $73.3 \%$ (Table 1). To assess repeatability of lipid determinations, lipid content was measured in triplicate subsamples of RT-004 by NIST Charleston and determined to be 55.8\% (1.3\%, 1 SD). The lipid content of RTDL-004 blubber was also determined by the NIST Gaithersburg laboratory and found to contain $56.9 \%$ lipid. Lipid content was measured in three samples of SRM 1945 and was determined to be $70.1 \%$ $(0.1 \%)$, compared to the certified value of $74.3 \% \pm 0.4 \%$. The percent total extractable organic content of the kidney tissues ranged from $5.25 \%$ to $45.2 \%$ (mean $=14.5 \%$; median $9.27 \%$ ) and that of the liver tissues ranged from $3.29 \%$ to $6.97 \%$ (mean $=4.88 \%$; median $=4.87 \%)$. 


\section{Blubber Analyses}

Quality Control: Several mechanisms were used to assess the accuracy and precision of data and to evaluate the comparability of data generated by the NIST Charleston and NIST Gaithersburg laboratories. POPs were determined by each laboratory in three aliquots of SRM 1945 that were analyzed with the rough-toothed dolphins (Table A1). Duplicate portions of six rough-toothed dolphin blubber specimens (RTDL-001 through RTDL-006) were analyzed by both the NIST Charleston and Gaithersburg laboratories. Results from these analyses are presented in Tables A2 and A3. The largest deviation was observed for PCB 18, where the relative deviation ranged from 33\% in RDTL-003 to 164\% in RTDL-004. The reason for the deviation was not known as the values for PCB 18 determined in SRM 1945 by both NIST Charleston and NIST Gaithersburg were within the $95 \%$ confidence interval of the certified value for this compound (4.48 $\mathrm{ng} / \mathrm{g}$ wet mass $\pm 0.88 \mathrm{ng} / \mathrm{g}$ wet mass). Repeatability within a batch was assessed by the NIST Charleston Laboratory through three analysis of RTDL-004 made in separate batches (Tables A3 and A4). The average percent relative standard deviation of measurements made on this sample was $6.42 \%(1.04 \%$ to $17.3 \%)$.

PCBs and Organochlorine Pesticides: Many target compounds including PCBs, DDTs, chlordanes, mirex, dieldrin, $\mathrm{HCHs}$, and $\mathrm{HCB}$ were detected in the nine female and six male (Table 2) rough-toothed dolphins analyzed (Tables A5 and A6, Figures A1-a,b). The concentrations of PCB congeners are given in Table A5. Organochlorine pesticides concentrations in the rough-toothed dolphin samples are given in Table A6. All results and comparisons to other studies are given on a lipid-mass basis unless otherwise noted. The results from the NIST Gaithersburg and NIST Charleston analyses were averaged.

PCBs were the organochlorine compounds found in greatest concentrations in the rough-toothed dolphins in this study. The sum of PCBs ( $\Sigma$ PCBs; sum of 31 individual congeners or congener groups) in female dolphin samples averaged 25,900 ng/g (range: $1,310 \mathrm{ng} / \mathrm{g}$ to $49,400 \mathrm{ng} / \mathrm{g}$ ) (Table A5). $\Sigma$ PCBs in males averaged 46,900 ng/g $\Sigma$ PCBs (range: 24,900 ng/g to 73,600 ng/g). PCB congener 153 contributed most to the $\Sigma$ PCBs with a mean percent contribution of $24 \%$ (range: $22 \%$ to $29 \%$ ) in females, and $26 \%$ in males (range: $24 \%$ to $29 \%$ ). Other PCB congeners detected at relatively high concentrations included PCBs 99, 101, 118, 138, 180, and 187 (Fig. A1-a).

When compared to cetaceans from studies in other geographic regions, the rough-toothed dolphins from this sample set have lower levels of $\Sigma$ PCBs (Table 2). For example, higher concentrations of $\Sigma$ PCBs have been observed in male Risso's dolphins (Grampus griseus; mean: $128,000 \mathrm{ng} / \mathrm{g}$ ) inhabiting coastal Japanese waters (Prudente et al. 1997, Table 2) and in stranded male striped dolphins (Stenella coeruleoalba) from the western Mediterranean Sea (mean: 1,300,000 ng/g; Kannan et al. 1993, Table 2). Kuehl and Haebler (1995) reported that male bottlenose dolphins that stranded on the Gulf Coast of Texas had a mean $\Sigma$ PCB concentration of 93,000 ng/g, which is higher than that of the rough-toothed dolphins (Table 2). Other studies examining stranded bottlenose dolphins from the Texas (Salata et al. 1995) and the Atlantic coasts (Kuehl et al., 1991) reported higher mean $\Sigma$ PCB concentrations- 36,100 ng/g and 60,600 $\mathrm{ng} / \mathrm{g}$, respectively (Table 2 ). 
With such a limited data set, and because so little is known about the relationship between the cycling of contaminants and the pelagic food web in the Gulf of Mexico, any conclusions about the differences in mean $\Sigma$ PCBs between coastal bottlenose dolphins and pelagic rough-toothed dolphins must be made with caution. We speculate that this difference is attributable primarily to habitat differences, as the near-shore waters of the Gulf of Mexico are in much closer proximity to potential point sources of PCBs resulting in higher contamination of the coastal food web and dolphin prey species. The pelagic rough-toothed dolphins' prey may have lower exposures and concentrations of PCBs, accounting for the difference in the $\Sigma$ PCBs. Additionally, the rough-toothed dolphins feed at a lower tropic level than the bottlenose dolphins, which would result in less biomagnification of contaminant levels.

The suggested toxic threshold concentration of PCBs in marine mammal blubber is 17,000 ng/g lipid mass (Kannan et al., 2000). Additionally, results from Lahvis et al. (1995) indicate that even relatively low levels of PCBs and DDTs can have negative effects on immune system function. Based on this criterion, it is likely that for the population represented by this limited sample group, PCBs pose a health risk. Unfortunately, little is understood about the mechanisms of cumulative actions of the complex mixtures of organochlorines to which these dolphins are exposed, and how these compounds impact the animals' health status (Marine Mammal Commission, 1999). Therefore, it is not currently possible to determine whether the health conditions and ultimate deaths of these dolphins were related to body burdens of POPs.

The DDT group compounds (2,4'-DDD, 4,4'-DDD, 2,4' DDE, 4,4'-DDE, 2,4'-DDT, and 4,4'DDT) were the organochlorine pesticide compounds present in the highest concentrations. In females, the average $\Sigma D D T$ concentration was $14,100 \mathrm{ng} / \mathrm{g}$ ranging from $298 \mathrm{ng} / \mathrm{g}$ to 34,900 $\mathrm{ng} / \mathrm{g}$ (Table A6). In males, the mean $\Sigma$ DDT was $22,100 \mathrm{ng} / \mathrm{g}$, ranging from $10,300 \mathrm{ng} / \mathrm{g}$ to 37,900 ng/g (Table A6). 4,4'-DDE was the DDT group compound present in the highest concentration, contributing $71 \%$ (range: $48 \%$ to $89 \%$ ) to $\Sigma$ DDTs in females, and $79 \%$ (range: $73 \%$ to $92 \%$ ) in males (Table A6). The male rough-toothed dolphins had mean $\Sigma$ DDT concentrations similar to those reported previously in several odonteceti species including Dall's porpoise (Phocoenoides dalli) from both the northeastern and northwestern Pacific (mean: 17,900 ng/g) and Pacific white-sided dolphins (Lagenorhynchus obliquidens) from the North Pacific (mean: 23,900 ng/g; Prudente et al., 1997, Table 2). Coastal bottlenose dolphins from the Gulf of Mexico (Salata et al., 1995) had a mean $\Sigma$ DDTs of $15,300 \mathrm{ng} / \mathrm{g}$, which was lower than the mean level found in the pelagic rough-toothed dolphins (mean $\Sigma$ DDTs of 17,400 for both sexes, Table 2). However, the maximum concentrations of $\Sigma$ DDTs in bottlenose dolphins from both the Gulf of Mexico $(74,600 \mathrm{ng} / \mathrm{g})$ and the Atlantic $(80,000 \mathrm{ng} / \mathrm{g})$ were more than double those measured in the rough-toothed dolphins (Salata et al., 1995, Kuehl et al., 1991, Table 2).

Prudente et al. (1997), Salata et al. (1995), Kuehl et al. (1991), and Kuehl and Haebler (1995) all reported that 4,4'-DDE contributed the most to EDDTs in all cetacean species they studied, consistent with our results. To better evaluate exposure to other DDT compounds and currentuse DDT, the percentage ratio of 4,4'-DDT to 4,4'-DDT + 4,4'-DDE was calculated (Figure 1). In females, the mean ratio was 18 (range: 13 to 38 ) and in males, the mean ratio was 9.2 (range: 3.0 to 16). Interestingly, the ratios were much higher in the rough-toothed dolphins than those from bottlenose dolphins that stranded in the Gulf of Mexico. The mean ratio in bottlenose 
dolphins that were analyzed by Salata et al. (1995) was 4.1, while the mean in dolphins analyzed by Kuehl and Haebler (1995) was 4.2. This difference may be attributable to two reasons. One explanation may be that the range of the rough-toothed dolphins in the Gulf of Mexico includes areas that are more heavily contaminated by current use DDT than the U.S. Gulf Coastal range of bottlenose dolphins. Mexico, which forms the western boundary of the Gulf of Mexico, currently uses DDT for mosquito control in amounts that exceed DDT usage by other Latin American countries (Lopez-Carrillo et al., 1996). If the rough-toothed dolphins feed in this region, it may explain their elevated levels of parent DDT compounds. A second explanation may be that rough-toothed dolphins have less ability than bottlenose dolphins to metabolize DDT compounds, perhaps because this species lacks the CYP2B gene that transcribes the cytochrome P450 mono-oxygenase isozyme responsible for metabolism of these compounds (Stegeman and Hahn, 1994).

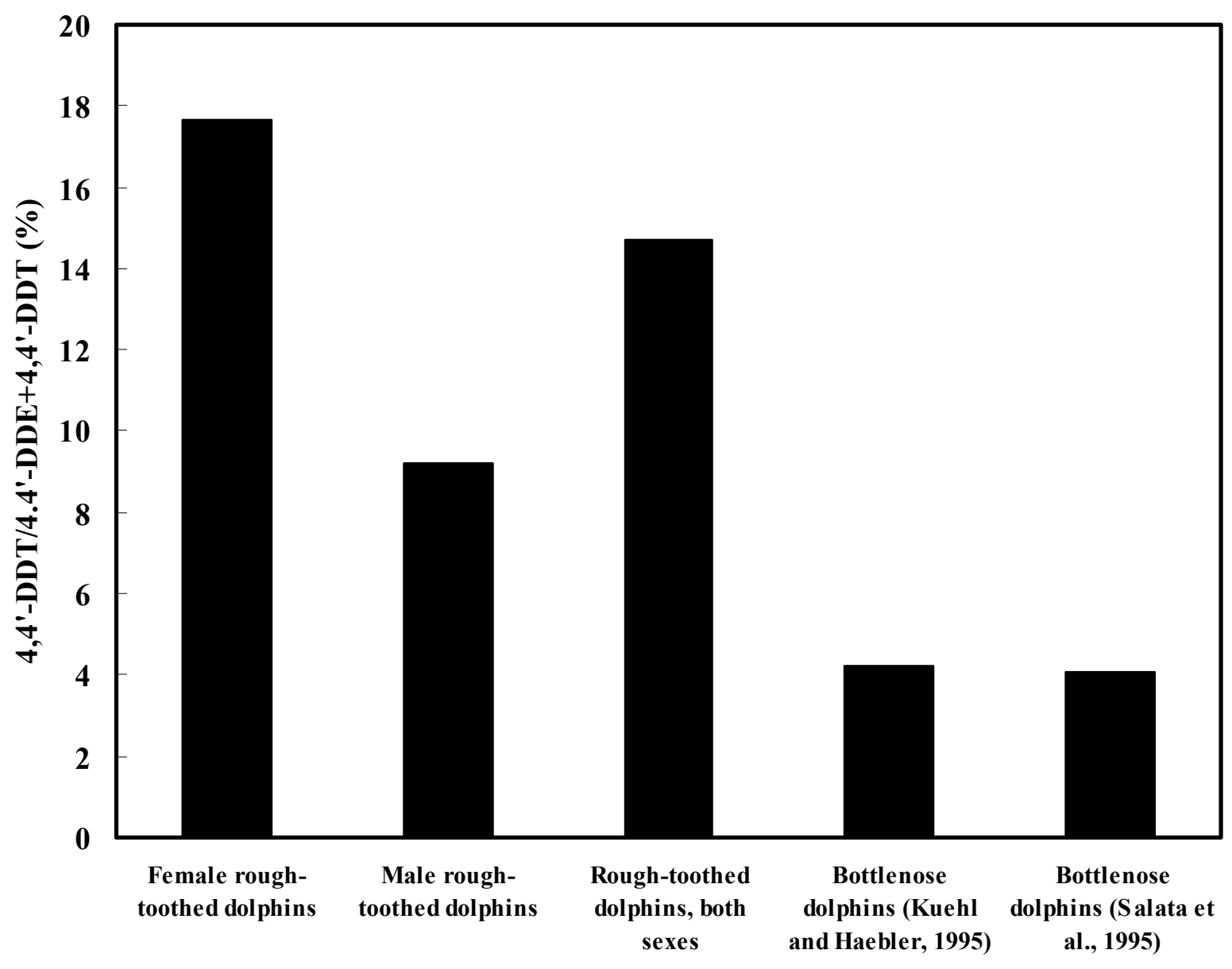

Figure 1: Comparison of the ratios of 4,4'-DDT to 4,4'-DDT + 4,4'-DDE (\%) in dolphin species from the Gulf of Mexico.

Following DDTs, the sum of chlordanes (Echlordanes; the sum of heptachlor, heptachlor epoxide, cis-nonachlor, trans-nonachlor, cis-chlordane, trans-chlordane, and oxychlordane) was 
the organochlorine pesticide group detected at highest concentration. $\Sigma$ chlordanes averaged $3,670 \mathrm{ng} / \mathrm{g}$ in females $(40.3 \mathrm{ng} / \mathrm{g}$ to $12,400 \mathrm{ng} / \mathrm{g})$ and 4,060 $\mathrm{ng} / \mathrm{g}$ in males $(1,620 \mathrm{ng} / \mathrm{g}$ to 8,200 ng/g, Table 2). Trans-nonachlor contributed the most to $\Sigma$ chlordanes, with a mean percentage of total in females of $61 \%$, ranging from $52 \%$ to $80 \%$, and in males of $70 \%$, ranging from $56 \%$ to $82 \%$. The highest mean concentrations of $\Sigma$ chlordanes found by Prudente et al. (1997) were in male Risso's dolphins from Japanese coastal waters; mean $\Sigma$ chlordanes were 12,800 ng/g, or approximately three times higher than the mean concentration measured in this set of roughtoothed dolphins (Table 2). This difference may be attributable to global fractionation of chlordane compounds resulting in higher levels at higher latitudes, and therefore greater contamination of prey species and ultimately top tier predators, a common trend with many organochlorines (Bidleman et al., 1998). Salata et al. (1995) reported a mean $\Sigma$ chlordanes concentration of $3,890 \mathrm{ng} / \mathrm{g}$ lipid mass in bottlenose dolphins of both sexes from the Gulf of Mexico, which was lower than the measured mean $\Sigma$ chlordanes concentration in the roughtoothed dolphins from this study (Table 2). However, if only levels of trans-nonachlor are compared, the mean concentrations from bottlenose dolphins inhabiting the coastal waters of both the Gulf of Mexico and the Atlantic (2170 ng/g lipid mass and $2930 \mathrm{ng} / \mathrm{g}$ lipid mass respectively) are approximately the same as those measured in the rough-toothed dolphins (2600 ng/g) (Salata et al., 1995; Kuehl et al., 1991).

Mirex, an organochlorine widely used as an insecticide and fire retardant until it was banned in 1978 (Smith et al., 1978), was detected in all of the rough-toothed dolphin samples in this study. The mean mirex concentration in female dolphin samples was $376 \mathrm{ng} / \mathrm{g}$ and ranged from 33.4 $\mathrm{ng} / \mathrm{g}$ to $912 \mathrm{ng} / \mathrm{g}$ (Table A6). Males had a mean mirex concentration of $710 \mathrm{ng} / \mathrm{g}$ with a range from $348 \mathrm{ng} / \mathrm{g}$ to $1,145 \mathrm{ng} / \mathrm{g}$ (Table A6). Male rough-toothed dolphins had mirex concentrations higher than those reported for male bottlenose dolphins also from the Gulf of Mexico (502 ng/g lipid mass; Kuehl and Haebler, 1995, Table 2). This was also true when the mean from both sexes $(517 \mathrm{ng} / \mathrm{g})$ was compared to that reported by Salata et al. (1995) for Gulf of Mexico bottlenose dolphins (485 ng/g, Table 2). However, the rough-toothed dolphins had more than double the mean mirex concentration of Atlantic bottlenose dolphins (194 ng/g, Kuehl et al., 1991, Table 2). The difference between concentrations of mirex in the rough-toothed dolphins and bottlenose dolphins from the Atlantic is probably due to extensive mirex application in the southeastern U.S. for fire ant control and because of the compound's chemical properties. Mirex is very hydrophobic and non-volatile, so is therefore unlikely, once it has entered the environment, to volatilize and form a latitudinal concentration gradient as is seen with many other POPs (Smith et al., 1978). The difference in mirex concentrations between animals from the Gulf of Mexico and the Atlantic may make mirex potentially useful as a marker compound to discriminate stocks of rough-toothed dolphins in these two regions. However, there are no data available on contaminant levels in rough-toothed dolphins from the Atlantic, so comparisons are not currently possible.

Dieldrin was detected in all of the rough-toothed dolphin samples analyzed. Dieldrin concentrations in female dolphin samples had a mean of $467 \mathrm{ng} / \mathrm{g}$ and ranged from $18.4 \mathrm{ng} / \mathrm{g}$ to $1,840 \mathrm{ng} / \mathrm{g}$ (Table A6). Males had a mean dieldrin concentration of $306 \mathrm{ng} / \mathrm{g}$ and ranged from $189 \mathrm{ng} / \mathrm{g}$ to $487 \mathrm{ng} / \mathrm{g}$ (Table A6). By comparison, adult male bottlenose dolphins analyzed by Kuehl and Haebler (1995) had a higher mean dieldrin concentration $(1,080 \mathrm{ng} / \mathrm{g})$ than that found in the rough-toothed dolphins from this study (Table 2). Salata et al. (1995) and Kuehl et al. 
(1991) also reported higher mean dieldrin concentrations in bottlenose dolphins of both sexes from the Gulf of Mexico and Atlantic (547 ng/g and $1450 \mathrm{ng} / \mathrm{g}$ respectively, Table 2).

HCHs were detected at relatively low levels in all individuals analyzed. In females, the mean concentration of $\Sigma \mathrm{HCHs}(\alpha-, \beta$-, and $\gamma-\mathrm{HCH})$ was $69.5 \mathrm{ng} / \mathrm{g}$, ranging from $5.29 \mathrm{ng} / \mathrm{g}$ to $268 \mathrm{ng} / \mathrm{g}$. The $\Sigma \mathrm{HCHs}$ in males averaged $23.0 \mathrm{ng} / \mathrm{g}$ and concentrations ranged from $14.5 \mathrm{ng} / \mathrm{g}$ to $45.1 \mathrm{ng} / \mathrm{g}$ (Table A6). In the majority of females, $\beta-\mathrm{HCH}$ contributed the most to $\Sigma \mathrm{HCHs}$, with a mean contribution of $66 \%$ to the $\Sigma \mathrm{HCH}$ (range from $38 \%$ to $100 \%$ ). However, in RTDL-003, only $\gamma$ $\mathrm{HCH}$ was detected, while in RTDL- $008, \alpha-\mathrm{HCH}$ contributed $100 \%$ to the $\Sigma \mathrm{HCH}$. In males, $\beta$ $\mathrm{HCH}$ contributed the most to $\Sigma \mathrm{HCHs}$, contributing an average of $74.5 \%$ to the $\Sigma \mathrm{HCH}$ (range from $64 \%$ to $85 \%$ ). The rough-toothed dolphins had lower concentrations of $\Sigma \mathrm{HCHs}$ compared to concentrations found in Dall's porpoise from the Japan Sea (mean: 7,140 ng/g, Prudente et al. 1997, Table 2). Coastal bottlenose dolphins from the Gulf of Mexico had mean $\beta-\mathrm{HCH}$ concentrations of $64.2 \mathrm{ng} / \mathrm{g}$ (Salata et al., 1995, Table 2). This was higher than the mean $\beta-\mathrm{HCH}$ concentration found in the rough-toothed dolphins. HCH patterns in the rough-toothed dolphins, with $\beta-\mathrm{HCH}$ being the dominant congener, were similar to those found by reported by Prudente et al. (1997) and Salata et al. (1995). Lower $\mathrm{SHCH}$ concentrations in rough-toothed dolphins relative to animals from waters adjacent to Asia were not surprising because most current $\mathrm{HCH}$ use is in India (Iwata et al., 1993). Additionally, Iwata et al. (1993) determined that there was a latitudinal concentration gradient with $\mathrm{HCHs}$ resulting in higher levels at higher latitudes, which would explain the relatively low levels of $\mathrm{HCHs}$ detected in these sub-tropical animals.

HCB concentrations were among the lowest of all POPs detected. Mean lipid mass HCB concentrations in female dolphins was $48.4 \mathrm{ng} / \mathrm{g}$ and ranged from $<1 \mathrm{ng} / \mathrm{g}$ to $70.9 \mathrm{ng} / \mathrm{g}$ (Table A6). Males had a mean HCB concentration of $48.2 \mathrm{ng} / \mathrm{g}$ and ranged from $20.8 \mathrm{ng} / \mathrm{g}$ to $79.5 \mathrm{ng} / \mathrm{g}$ (Table A6). The highest concentration of HCB detected by Prudente et al. (1997) was in Dall's porpoises (Phocoenoides dalli) from the Sea of Japan, with a mean HCB concentration of 1,430 $\mathrm{ng} / \mathrm{g}$ (Table 2). These authors suggest that HCB distribution is heavily dependent upon temperature due to its high volatility, with $\mathrm{HCB}$ partitioning mainly to cold areas or higher latitudes. This could explain why animals from the sub-tropical Gulf of Mexico, such as the rough-toothed dolphins, or bottlenose dolphins (mean: $510 \mathrm{ng} / \mathrm{g}$; Salata et al., 1995, Table 2) have lower concentrations of HCB.

The variability of levels of organochlorines caused by gender and age is an interesting feature of this data set. Unfortunately, the data set is small $(n=15)$ and limited by the absence of some age groups, thus limiting a complete interpretation. For instance, older males, typically having the highest POP concentrations, are not represented. However, age and gender trends in the POP data can still be observed even with this limitation. One interesting feature of the data, and one of concern, is the relatively high POP concentrations in the immature dolphins (Figure 2). 
Table 2: Comparison of organochlorine concentrations (ng/g lipid mass) among dolphin species and locations. See footnote for the number of PCB congeners summed to derive $\Sigma$ PCB.

\begin{tabular}{|c|c|c|c|c|c|c|c|c|c|c|}
\hline Species & $\mathbf{n}$ & Sex & $\Sigma$ PCBs & $\Sigma$ DDTs & ¿Chlordanes & Mirex & Dieldrin & HCB & $\Sigma$ HCHs & Reference \\
\hline \multirow[t]{2}{*}{ Rough-toothed dolphin } & 6 & M & $\begin{array}{c}\mathbf{4 6 , 9 0 0} \\
24,900-73,600\end{array}$ & $\begin{array}{c}\mathbf{2 2 , 1 0 0} \\
10,300-37,900\end{array}$ & $\begin{array}{c}\mathbf{4 , 0 6 0} \\
1,620-8,200\end{array}$ & $\begin{array}{c}\mathbf{7 1 0} \\
348-1,150\end{array}$ & $\begin{array}{c}\mathbf{3 0 6} \\
186-487\end{array}$ & $\begin{array}{c}\mathbf{6 2 . 0} \\
20.8-92.0\end{array}$ & $\begin{array}{c}\mathbf{2 3 . 0} \\
14.5-23.9\end{array}$ & this study \\
\hline & 9 & $\mathrm{~F}$ & $\begin{array}{c}\mathbf{2 5 , 9 0 0} \\
1,310-38,100\end{array}$ & $\begin{array}{c}\mathbf{1 4 , 1 0 0} \\
298-34,900\end{array}$ & $\begin{array}{c}\mathbf{3 , 7 0 0} \\
40.3-12,400\end{array}$ & $\begin{array}{c}\mathbf{3 7 6} \\
33.4-912\end{array}$ & $\begin{array}{c}\mathbf{4 6 7} \\
18.4-907\end{array}$ & $\begin{array}{c}\mathbf{4 8 . 2} \\
<2-70.9\end{array}$ & $\begin{array}{c}\mathbf{5 9 . 5} \\
5.29-267\end{array}$ & this study \\
\hline Bottlenose dolphin & 12 & $\mathrm{M} / \mathrm{F}$ & $\begin{array}{c}\mathbf{6 0 , 6 0 0} \\
17,400-196,000\end{array}$ & $\begin{array}{c}15200 * \\
519-80,000 *\end{array}$ & $\begin{array}{c}\mathbf{2 9 3 0} * * \\
172-9,200 * *\end{array}$ & $\begin{array}{c}194 \\
36-584\end{array}$ & $\begin{array}{c}\mathbf{1 , 4 5 0} \\
74.0-5,820\end{array}$ & $\begin{array}{l}-- \\
--\end{array}$ & $\begin{array}{l}-- \\
--\end{array}$ & (1) \\
\hline Bottlenose dolphin & 9 & M & $\begin{array}{c}\mathbf{9 3 , 0 0 0} \\
64,000-187,000\end{array}$ & $\begin{array}{c}\mathbf{3 7 , 0 0 0 *} \\
15,000 / 78,000 *\end{array}$ & $\begin{array}{l}-- \\
--\end{array}$ & $\begin{array}{c}\mathbf{5 0 2} \\
271-810\end{array}$ & $\begin{array}{c}\mathbf{1 , 0 8 0} \\
290-1,800\end{array}$ & $\begin{array}{l}-- \\
--\end{array}$ & $\begin{array}{l}-- \\
--\end{array}$ & (2) \\
\hline Bottlenose dolphin & 33 & $\mathrm{M} / \mathrm{F}$ & $\begin{array}{c}\mathbf{3 6 , 1 0 0} \\
4,100-149,000\end{array}$ & $\begin{array}{c}15,300 \\
428-76,000\end{array}$ & $\begin{array}{c}\mathbf{3 , 8 9 0} \\
190-28,400\end{array}$ & $\begin{array}{c}\mathbf{4 8 5} \\
167-6,540\end{array}$ & $\begin{array}{c}\mathbf{5 4 7} \\
28.7-2,030\end{array}$ & $\begin{array}{c}\mathbf{5 1 0} \\
19.8-2,180\end{array}$ & $\begin{array}{c}64.2 * * * \\
<1-924 * * *\end{array}$ & (3) \\
\hline Risso's dolphin & 5 & M & $\begin{array}{c}\mathbf{1 2 8 , 0 0 0} \\
88,400-151,000\end{array}$ & $\begin{array}{l}-- \\
--\end{array}$ & $\begin{array}{c}\mathbf{1 2 , 8 0 0} \\
7,210-17,400\end{array}$ & $\begin{array}{l}-- \\
--\end{array}$ & $\begin{array}{l}-- \\
--\end{array}$ & $\begin{array}{l}-- \\
--\end{array}$ & $\begin{array}{l}-- \\
--\end{array}$ & (4) \\
\hline Striped dolphin & 9 & M & $\begin{array}{c}\mathbf{1 , 3 0 0 , 0 0 0} \\
88,400-2,6000,000\end{array}$ & $\begin{array}{l}-- \\
--\end{array}$ & $\begin{array}{l}-- \\
--\end{array}$ & $\begin{array}{l}-- \\
--\end{array}$ & $\begin{array}{l}-- \\
--\end{array}$ & $\begin{array}{l}-- \\
--\end{array}$ & -- & (5) \\
\hline Dall's porpoise & 3 & M & -- & $\begin{array}{c}\mathbf{1 7 , 9 0 0} \\
9,760-33,300\end{array}$ & $\begin{array}{l}-- \\
--\end{array}$ & $\begin{array}{l}-- \\
--\end{array}$ & $\begin{array}{l}-- \\
--\end{array}$ & $\begin{array}{c}1,430 \\
813-2,310\end{array}$ & $\begin{array}{c}7,140 \\
6,260- \\
8,570\end{array}$ & (4) \\
\hline Pacific white-sided dolphin & 3 & M & $\begin{array}{l}-- \\
--\end{array}$ & $\begin{array}{c}\mathbf{2 3 , 9 0 0} \\
21,600-28,400\end{array}$ & $\begin{array}{l}-- \\
--\end{array}$ & $\begin{array}{l}-- \\
--\end{array}$ & $\begin{array}{l}-- \\
--\end{array}$ & $\begin{array}{l}-- \\
--\end{array}$ & -- & (4) \\
\hline
\end{tabular}

*4,4'-DDE only

**trans-nonachlor only

*** $\beta-\mathrm{HCH}$ only

(1) Kuehl et al. (1991); Western Atlantic (85 PCB congeners summed)

(2) Kuehl et al. (1995); Gulf of Mexico (number of PCB congeners summed not stated)

(3) Salata et al. (1995); Gulf of Mexico (number of PCB congeners summed not stated)

(4) Prudente et al. (1997); North-western Atlantic (55 PCB congeners summed)

(5) Kannan et al. (1993); Mediterranean (number of PCB congeners summed not stated) 
It is well established that mothers transfer organochlorines to their offspring via lactation (e.g., Addison and Brodie, 1987). While the authors could not find any published information on the nursing duration of rough-toothed dolphin calves, there is information on bottlenose dolphins. Assuming that the botttlenose dolphin calves nurse for similar lengths of time, rough-toothed dolphin calves under the age of 18 months were likely receiving most or all of their nutrients from their mothers' milk (Cockroft and Ross, 1990). For calves whose mothers have had previous offspring, the risk of negative health effects from POPs is diminished as females may offload up to $80 \%$ of their body burden to their first-born calves (bottlenose dolphins, Cockroft et al., 1989). This would explain the elevated levels seen in the young rough-toothed dolphins (Figure 2). The elevated levels in RTDL-007, a pregnant female, suggest that she was carrying her first calf and had not yet off-loaded her body burden to a previous offspring. Unfortunately, none of the neonates were available for analysis, which could have provided information about parturitional transfer of POPs in this species. Previously, it has been suggested that the predominantly lactational transfer of POPs to first-born calves may have serious health implications including increased mortality (Cockroft et al., 1989) Considering that so little is known about many of the details of the rough-toothed dolphins life history, this is an area warranting further study.

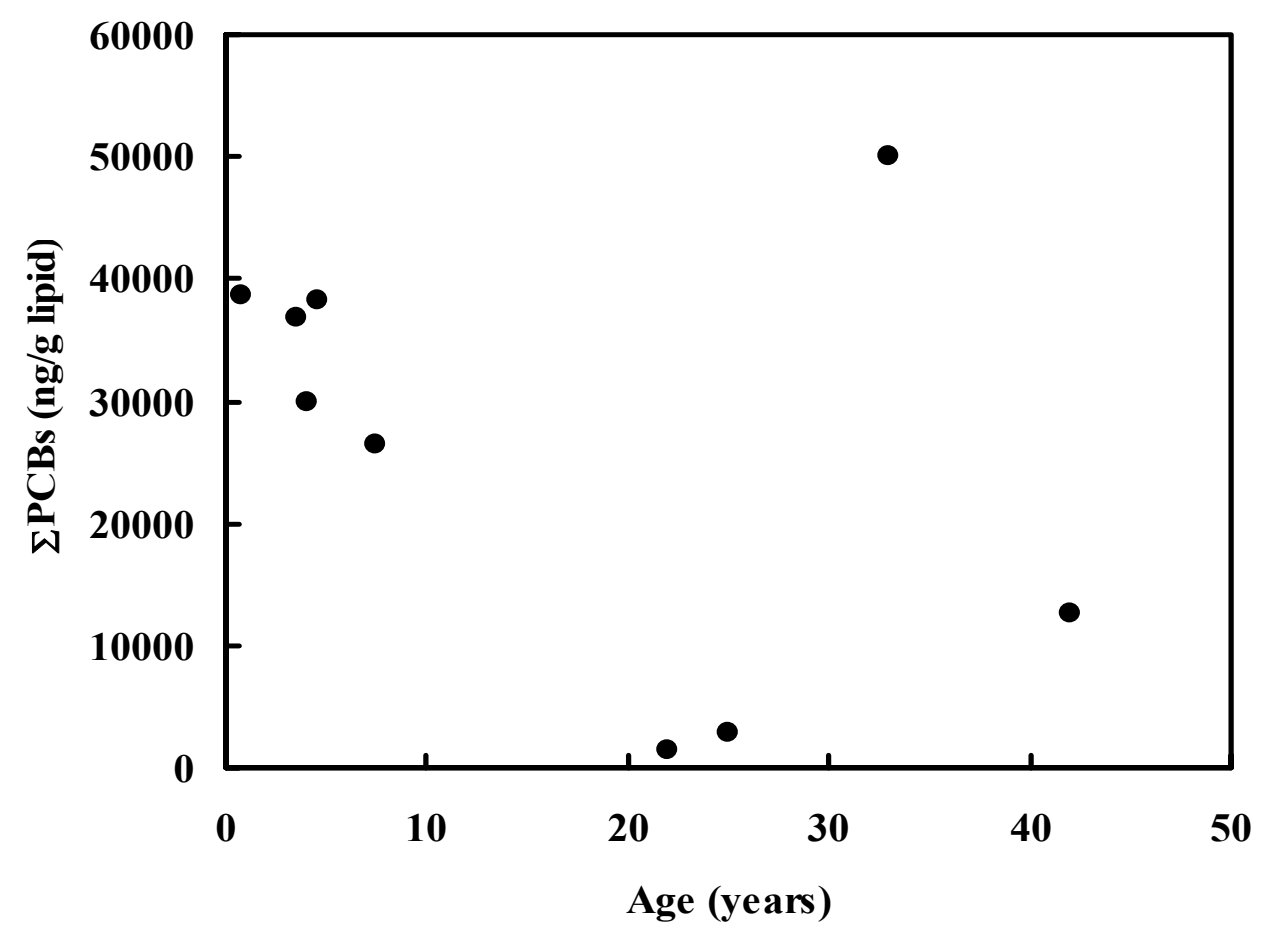

Figure 2: Age versus $\Sigma \mathrm{PCB}$ congeners (ng/g lipid mass) for female rough-toothed dolphins. 


\section{Liver and Kidney Analyses}

Results of INAA and ICP-MS analyses to determine inorganic constituents in kidney and liver tissues of the 15 rough-toothed dolphins are discussed below. For each method, analyses were performed on duplicate sample portions and results from analyses on these individual portions are presented in Table B3, Appendix B. Duplicate portions of SRM 1566a Oyster Tissue and of Whale Liver Homogenate I were used as control materials for INAA and one portion of Whale Liver Homogenate I was used for the ICP-MS analyses. Results for these materials are shown in Tables B4, B5, and B6 in Appendix B. In general, values determined by INAA and ICP-MS agree with certified values, reference values, or literature values.

Analysis of Duplicate Subsamples: For most elements, the values from INAA and ICP-MS of duplicate portions agree within the total uncertainties listed for each method. Poor agreement between duplicate portions was observed for $\mathrm{Pb}$ in all tissues, $\mathrm{Ca}$ in three kidney specimens and two liver specimens, $\mathrm{Cd}$ in one liver specimen, and for several elements in the kidney tissue with highest lipid content (RTDL-013).

Values for $\mathrm{Pb}$ in a given sub-sample varied by as much as two orders of magnitude. It is unlikely that the tissues are inhomogeneous with respect to lead. It is probable that the observed inhomogeneity is the result of contamination of the tissues either during collection or processing of the sub-samples. Identification of the source of contamination is under investigation. For this reason, the values for $\mathrm{Pb}$ are not included in this report.

Calcium values from duplicate portions showed poor agreement in several of the specimens. Poor agreement for duplicate portions was observed for liver tissues from RTDL-003 and RTDL-007 and for kidney tissues from RTDL-005, -007, and -008. The kidney tissues of these animals contained greater amounts of lipid material than the others (see Table B1). Although kidney lipid levels were highest for RTDL-013, Ca values in this specimen were below the INAA detection limit of $16 \mathrm{mg} / \mathrm{kg}$. This type of apparent $\mathrm{Ca}$ inhomogeneity was found in beluga whale kidney tissues that were known to contain Ca nodules (Becker, 2000). Tissue mineralization is not uncommon and could result in tissues that contain small $\mathrm{Ca}$ deposits that are not homogeneously distributed, even after cryogenic homogenization.

The values from the duplicate sub-samples of the kidney tissue containing the highest amount of lipid, from animal RTDL-013, showed poor agreement for the elements $\mathrm{Na}, \mathrm{Cl}, \mathrm{K}$, and $\mathrm{Br}$ which are short-lived NAA products. For this reason, an additional sub-sample was included in the subsequent analysis of long-lived products of NAA. Values among these three portions were inconsistent. The portions from this tissue were too oily to be easily removed from the LPE bags after the long irradiation. It is possible that inconsistent LPE film element content contributed to the observed variation; however it is more likely that the sub-samples from this tissue are inhomogeneous. Values for several of the electrolytes in duplicate portions of the tissues with high lipid content were inconsistent and were generally lower than those in the other tissues. Electrolytes are hydrophilic rather than lipophilic so that these results may be expected.

Electrolytes: $\mathrm{Na}, \mathrm{Mg}, \mathrm{Ca}, \mathrm{Cl}, \mathrm{K}, \mathrm{Br}$ : Although most researchers do not determine electrolyte levels in marine mammal tissues, results of this study were compared with other INAA results from analysis of marine mammal tissues from the NBSB. In general, INAA of marine mammal 
liver tissues has shown that concentrations of electrolytes vary little from animal to animal, or among species (Mackey et al., 1995). Levels of most of the electrolytes in liver and kidney of rough-toothed dolphins are consistent with this finding. Values of the relative standard deviation for $\mathrm{Na}, \mathrm{Mg}, \mathrm{Cl}, \mathrm{K}$, and $\mathrm{Br}$ for these 15 rough-toothed dolphin liver tissues ranged from $9 \%$ to $13 \%$. Little variation was observed because these elements are essential and are regulated biochemically. Levels of $\mathrm{Na}, \mathrm{Mg}, \mathrm{Cl}, \mathrm{K}, \mathrm{Br}$, and $\mathrm{Cs}$ in these tissues are similar to those found in NBSB tissues of several other odontocetae including white-sided dolphin, pilot whale, harbor porpoise, and beluga whale. See Tables 3 and 4.

Levels of Ca were high and amounts in duplicate portions varied greatly in kidneys of three rough-toothed dolphins (RTDL-005, -007, and -008) and in livers of two (RTDL-003, RTDL007). The three kidney specimens were those with high lipid content (20\% to $32 \%)$. Calcium values were below the INAA detection limit (of about $16 \mathrm{mg} / \mathrm{kg}$ ) in the specimen (RTDL-013) containing the largest amount of extractable organic material (45\%). Calcium levels found in the rough-toothed dolphins were similar to those found in the beluga whales from Cook Inlet (Becker et al., 2001) which contained calcified nodules and were inhomogeneous with respect to $\mathrm{Ca}$. Tissue calcification has been associated with connective tissue kidney lesions in humans (Selye, 1961) and with carcinoma (see e.g., Davidson et al, 1990.)

Table 3: Comparison of concentration ranges ( $\mathrm{mg} / \mathrm{kg}$ wet mass) of trace elements in kidneys of rough-toothed dolphins and those of other odontocetae.

\begin{tabular}{|c|c|c|c|c|c|}
\hline & $\begin{array}{l}\text { Rough-Toothed } \\
\text { Dolphins } n=15\end{array}$ & $\begin{array}{c}\text { Beluga Whales } \\
\mathrm{n}=10\end{array}$ & $\begin{array}{c}\text { Beluga Whales } \\
n=37\end{array}$ & $\begin{array}{c}\text { Common Dolphin } \\
\mathrm{n}=18\end{array}$ & $\begin{array}{c}\text { Harbor Porpoise } \\
n=23\end{array}$ \\
\hline & This work & Becker et al. (2001) & Hansen et al. (1990) & Law et al. (1994) & Law et al. (1994) \\
\hline $\mathrm{Na}$ & $1021-2297$ & $1884-2350$ & -- & -- & -- \\
\hline $\mathrm{Mg}$ & $47-205$ & $86-165$ & -- & -- & -- \\
\hline $\mathrm{Cl}$ & $1257-2932$ & $1811-2688$ & -- & -- & -- \\
\hline $\mathrm{K}$ & $932-3013$ & $1814-2223$ & -- & -- & -- \\
\hline $\mathrm{Ca}$ & $57-1197$ & $69-2232^{a}$ & -- & -- & -- \\
\hline $\mathrm{V}$ & $\leq 0.04$ & $\leq 0.04$ & -- & -- & -- \\
\hline $\mathrm{Mn}$ & $0.172-1.06$ & $0.38-1.24$ & -- & -- & -- \\
\hline $\mathrm{Cu}$ & $\leq 4$ & $\leq 5$ & -- & $1.9-7.6$ & $2.3-15$ \\
\hline $\mathrm{Br}$ & $14.2-25.5$ & $15-28$ & -- & -- & -- \\
\hline $\mathrm{Fe}$ & $30-77$ & $58-155,732^{b}$ & -- & -- & -- \\
\hline Co & $0.004-0.013$ & $0.006-0.018$ & -- & -- & -- \\
\hline $\mathrm{Zn}$ & $8.6-18.7$ & $19-30$ & $15-40(27.2)$ & $12-35$ & $16-45$ \\
\hline As & $\leq 0.5-0.7$ & $\leq 0.06-0.21^{\mathrm{c}}$ & -- & $0.8-1.4(\mathrm{n}=7)$ & -- \\
\hline $\mathrm{Se}$ & $2.4-11$ & $0.41-3.87$ & $0.34-4.24(2.2)$ & $1.9-3.9(\mathrm{n}=11)$ & $0.6-4.9$ \\
\hline $\mathrm{Rb}$ & $0.41-1.4$ & $0.7-1.8$ & -- & -- & -- \\
\hline $\mathrm{Ag}$ & $\leq 0.005-0.015$ & $\leq 0.005-0.02,36.7^{\mathrm{d}}$ & -- & -- & -- \\
\hline $\mathrm{Cd}$ & $0.01-1.02^{\mathrm{e}}$ & $2.2-9.0$ & $\leq 0.015-28.7(10.3)$ & $0.12-9.3$ & $\leq 0.07-8.7$ \\
\hline Cs & $0.025-0.068$ & $0.045-0.11$ & -- & -- & -- \\
\hline $\mathrm{Hg}$ & $0.9-15^{\mathrm{e}}$ & -- & $\leq 0.005-8.88$ & $0.3-6.0$ & $\leq 0.01-37$ \\
\hline
\end{tabular}

\footnotetext{
${ }^{a}$ These kidneys were inhomogeneous with respect to Ca because of the presence of calcified nodules in the tissue.

${ }^{\mathrm{b}}$ Concentrations for nine kidneys ranged from $58 \mathrm{mg} / \mathrm{kg}$ to $155 \mathrm{mg} / \mathrm{kg}$; the value for the remaining tissue was $732 \mathrm{mg} / \mathrm{kg} \pm 22 \mathrm{mg} / \mathrm{kg}(1$ SD)

${ }^{\mathrm{c}}$ Arsenic levels for seven of the ten kidneys were below the detection limit of $0.06 \mathrm{mg} / \mathrm{kg}$ and the remaining three values ranged from 0.14 $\mathrm{mg} / \mathrm{kg}$ to $0.21 \mathrm{mg} / \mathrm{kg}$.

${ }^{\mathrm{d}}$ Silver levels in seven of the ten kidneys were below the below the detection limit of about $0.005 \mathrm{mg} / \mathrm{kg}$, concentrations in two kidneys were $0.01 \mathrm{mg} / \mathrm{kg}$ and $0.02 \mathrm{mg} / \mathrm{kg}$, and the remaining value was $37 \mathrm{mg} / \mathrm{kg} \pm 4 \mathrm{mg} / \mathrm{kg}$ (1 SD).

${ }^{\mathrm{e}}$ Values were determined by ICP-MS
} 
Essential Trace Metals: Mn, Co, $\mathbf{C u}, \mathrm{Zn}$, Se: Levels of four of these essential trace elements in liver tissues of rough-toothed dolphins also showed little animal-to-animal variation. Values for the relative standard deviation for $\mathrm{Mn}, \mathrm{Co}, \mathrm{Cu}$, and $\mathrm{Zn}$ ranged from about $10 \%$ to $25 \%$. As was the case with electrolytes, this relatively narrow range of values was expected since these elements are essential and are regulated biochemically. The ranges of values found for these elements in rough-toothed dolphin liver and kidney were generally similar to those reported for other marine mammal species. See Tables 3 and 4.

Although Se is an essential element, much greater animal-to-animal variation was observed for Se concentrations than for the other essential elements. Selenium mass fractions ranged from 2.9 $\mathrm{mg} / \mathrm{kg}$ to $122 \mathrm{mg} / \mathrm{kg}$ in liver tissues and from $2.6 \mathrm{mg} / \mathrm{kg}$ to $11.1 \mathrm{mg} / \mathrm{kg}$ in kidney tissues. Values for the relative standard deviation of selenium were $40 \%$ for concentrations in kidney and $110 \%$ for liver. Similar ranges have been reported for other marine mammal species. This comparatively wide range of values was probably due to the role of selenium in metal detoxification (Frost and Lish, 1975; Hammond and Beliles, 1980). Selenium or seleno-proteins may assist in the removal of several toxic metals so that Se concentrations often increase with increasing concentrations of other metals. Koemann et al. (1973) first reported a linear correlation between $\mathrm{Se}$ and $\mathrm{Hg}$ in liver tissues. Since then, many other researchers have also observed this relationship (e.g., Julshamn et al., 1987; Meador et al., 1993; Mackey et al., 1996). Hepatic Se concentrations also increase with those of $\mathrm{Ag}$ in several species of odontocetae (Becker et al., 1995).

Selenium values were slightly higher in the rough-toothed dolphin kidneys when compared with levels found in tissues of other species. The Se concentrations in kidney tissues containing a higher amount of lipid appeared to be slightly higher than in tissues with a lower amount of lipid. Selenium values from animals RTDL-003, $-005,-007,-008$, and -013 , ranged from $6.9 \mathrm{mg} / \mathrm{kg}$ to $11.1 \mathrm{mg} / \mathrm{kg}$, whereas the range for the remaining tissues was $2.4 \mathrm{mg} / \mathrm{kg}$ to $5.9 \mathrm{mg} / \mathrm{kg}$. Selenium values in the liver tissues from those dolphins were also higher (with a range of $33 \mathrm{mg} / \mathrm{kg}$ to 122 $\mathrm{mg} / \mathrm{kg}$ ) in the animals whose kidneys contained higher lipid amounts (RTDL-003, -005, -007, -008 and -013 ) compared to a range of $2.9 \mathrm{mg} / \mathrm{kg}$ to $28 \mathrm{mg} / \mathrm{kg}$ for the remaining animals. The number of tissues analyzed was insufficient to determine whether this difference was significant. Similar patterns were observed for $\mathrm{Hg}$, which is discussed below.

Potentially Toxic Metals: As, Ag, Cd, Hg: Levels of As in rough-toothed dolphins were below the INAA detection limit of $0.06 \mathrm{mg} / \mathrm{kg}$ in 14 of the 15 kidney tissues analyzed and ranged from $0.2 \mathrm{mg} / \mathrm{kg}$ to $0.6 \mathrm{mg} / \mathrm{kg}$ in rough-toothed dolphin liver tissues. These ranges were consistent with values reported for other species of marine mammal. Hepatic As levels in roughtoothed dolphins were similar to those found in harbor porpoise and the range overlaps ranges reported for several other species of marine mammals (Table 4).

Levels of $\mathrm{Ag}, \mathrm{Cd}$, and $\mathrm{Hg}$ in rough-toothed dolphin tissues showed much greater animal-toanimal variation than As. The relative standard deviations of the average values for these elements ranged from about $50 \%$ to well over $100 \%$, as values for a given element span several orders of magnitude. The elements $\mathrm{Ag}, \mathrm{Cd}$, and $\mathrm{Hg}$ are probably not essential, and have no known specific biochemical regulatory pathways in mammals. These metals often accumulate in liver and kidney tissues over time (e.g., Mackey et al., 1996). Results from ICP-MS showed that 
renal $\mathrm{Cd}$ values ranged from $0.05 \mathrm{mg} / \mathrm{kg}$ to $3.94 \mathrm{mg} / \mathrm{kg}$. These values are similar to the levels found in the kidneys of other marine mammals from the NBSB and with selected literature values (Table 3). Levels of $\mathrm{Hg}$ in rough-toothed dolphin kidneys also spanned two orders of magnitude, consistent with ranges observed in other species (see Table 3). Hepatic Hg in roughtoothed dolphins RTDL-003, -007 and -013 represented some of the higher values $(175 \mathrm{mg} / \mathrm{kg}$, $180 \mathrm{mg} / \mathrm{kg}$, and $235 \mathrm{mg} / \mathrm{kg}$ ) observed for tissues from the NBSB. The hepatic $\mathrm{Hg}$ values for rough-toothed dolphins were within the range of values reported for other odontocetae such as Mediterranean striped dolphins (Stenella coeruleoalba;1.2 mg/kg to $1544 \mathrm{mg} / \mathrm{kg}$; Andre et al, 1991) and were similar to the values for harbor porpoise reported by Law et al., 1992. (See Table 4.)

Table 4: Comparison of concentration ranges $(\mathrm{mg} / \mathrm{kg}$ of wet mass) of selected trace elements in livers of rough-toothed dolphins with ranges for other odontocetae.

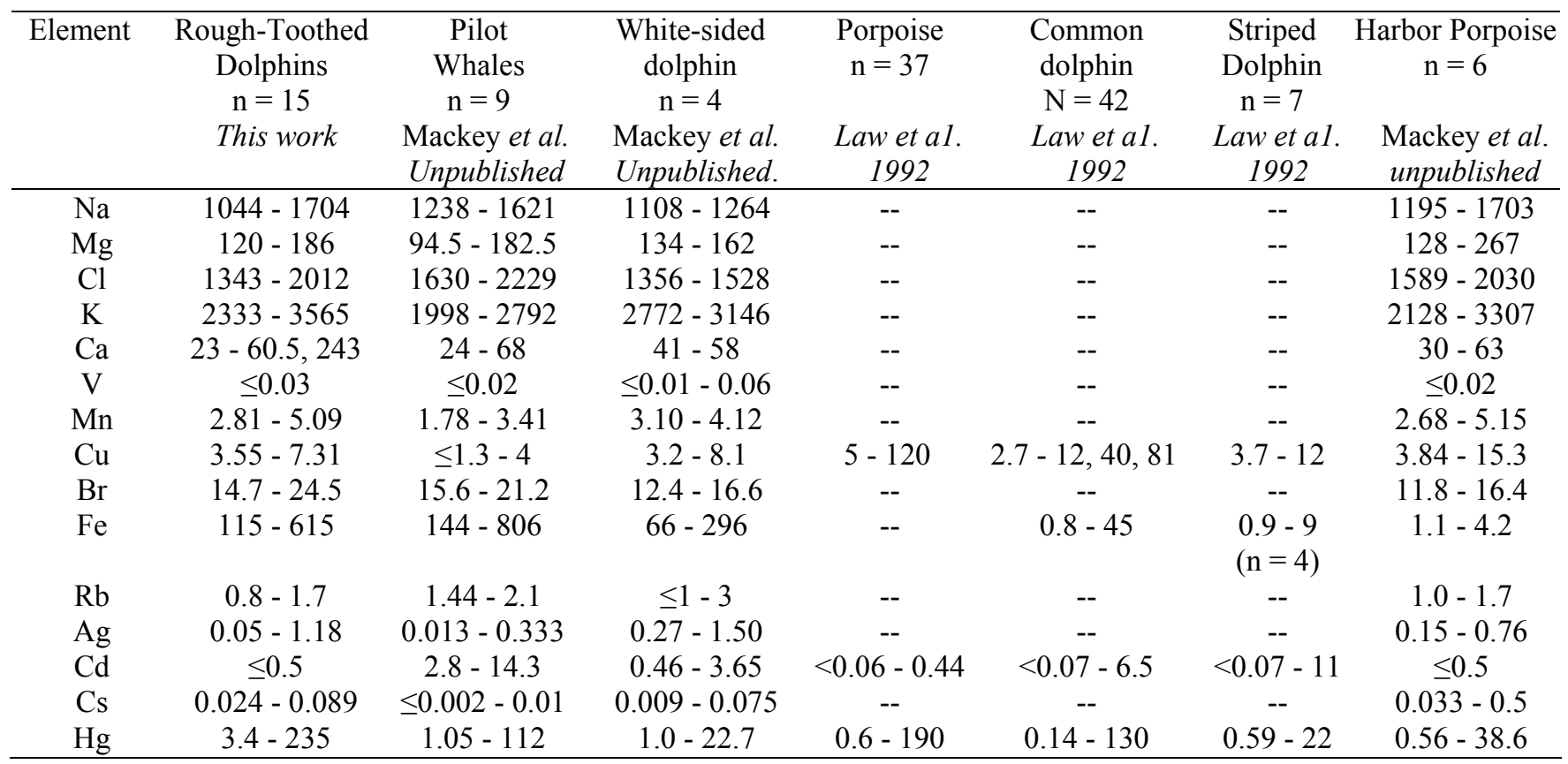

Relationship between liver and kidney: In general, no strong relationships were found between element concentrations in kidney and liver. Concentrations of Se in liver and kidney appeared to be correlated with a linear correlation coefficient of $0.75(p<0.002$; Figure 3$)$. No other significant linear correlation relationships were observed between the two tissues.

Element Accumulation with Age: Liver and kidney may serve as repositories for some trace elements. Data from this study were analyzed to determine whether any elements increased with increasing animal age. Results indicated that $\mathrm{Se}, \mathrm{Hg}, \mathrm{Ag}$, and $\mathrm{Sn}$ accumulated in rough-toothed dolphin liver and that $\mathrm{Hg}$ and Se accumulated in kidney tissues. 


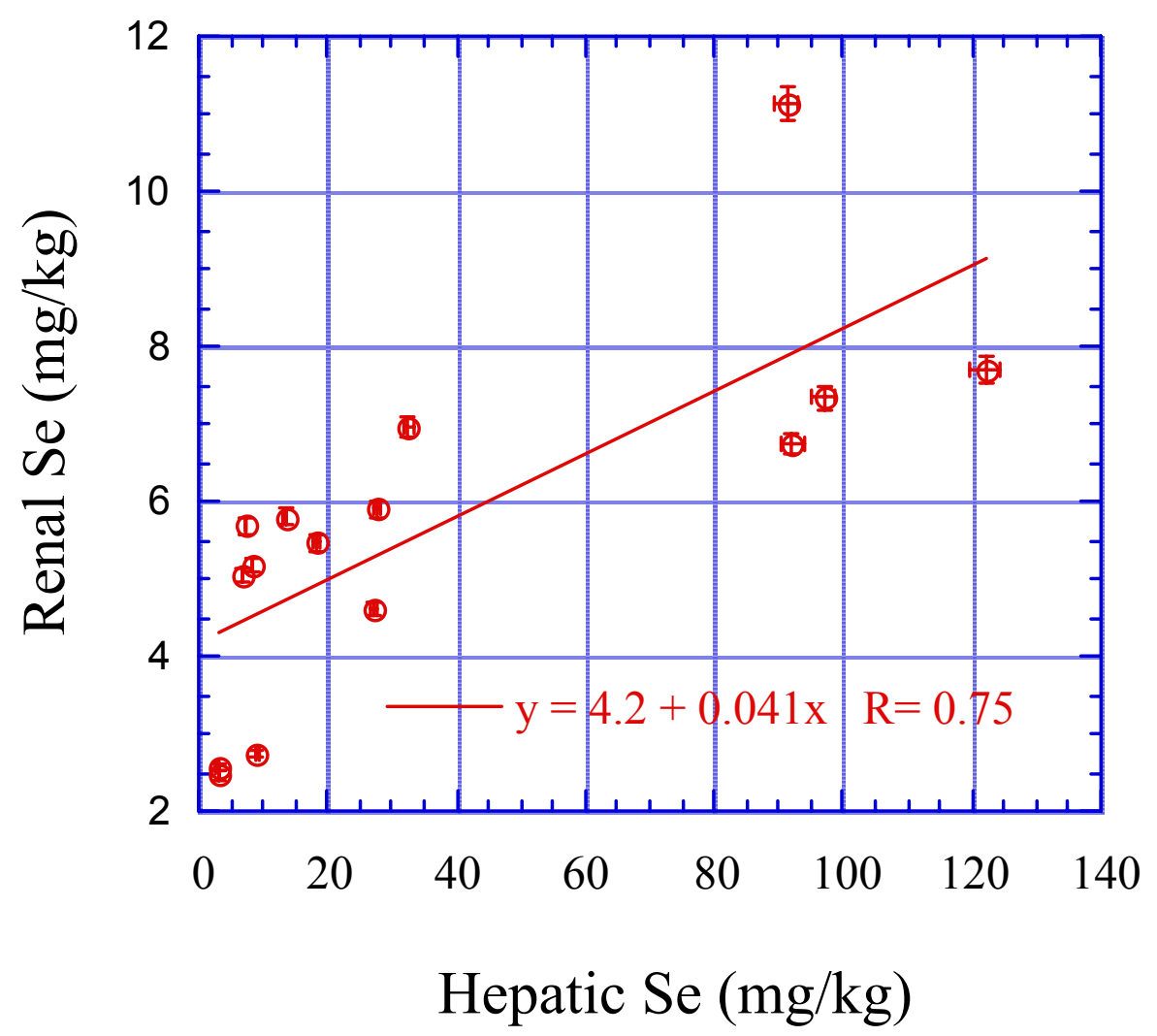

Figure 3: Renal and hepatic Se concentrations $(\mathrm{mg} / \mathrm{kg})$ in rough-toothed dolphins.

Several researchers observed that levels of $\mathrm{Hg}$ and Se were correlated and increase over time in liver tissue of several mammalian species. This relationship was thought to be the result of Se assisting in the detoxification of $\mathrm{Hg}$ or its compounds (Koeman et al, 1975; Martoja and Viale 1977). Results of this work indicated that Se and $\mathrm{Hg}$ accumulated with age in both liver and kidney of rough-toothed dolphins (Figures 4 and 5). The linear correlation coefficient (r) for hepatic Se concentrations versus age was 0.77, and for hepatic Hg versus age, $r=0.96$. The linear correlation coefficient for renal Se concentrations vs. age was 0.95 , and that for renal $\mathrm{Hg}$ was 0.92 . Accumulation of $\mathrm{Hg}$ and $\mathrm{Se}$ with age was reported in many marine mammal species. (See, e.g., Koeman et al., 1975; Wagemann et al., 1983; Meador et al., 1993.)

Less is known about levels of $\mathrm{Sn}$ in marine mammal tissues. Most researchers do not determine $\mathrm{Sn}$. There are some data on levels of the butyltin compounds in marine mammal tissues. Law et al. (1998) report that levels of total butyltin compounds in liver tissues of porpoises and grey seals (Halichoerrs grypus) ranged from $0.01 \mathrm{mg} / \mathrm{kg}$ to $0.6 \mathrm{mg} / \mathrm{kg}$ and levels as high as $10 \mathrm{mg} / \mathrm{kg}$ have been reported (Iwata et al., 1995). Levels of Sn in livers of these animals ranged from 0.08 $\mathrm{mg} / \mathrm{kg}$ to $1.10 \mathrm{mg} / \mathrm{kg}$. Levels in kidney tissues ranged from the ICP-MS detection limit of 0.02 $\mathrm{mg} / \mathrm{kg}$ to $0.14 \mathrm{mg} / \mathrm{kg}$. Hepatic Sn was linearly correlated with animal age $(\mathrm{r}=0.95)$ indicating accumulation in liver tissues with time (Figure 6). Hepatic Ag concentrations $(r=0.90)$ also increased with animal age. This was also observed for several species of marine mammals from the NBSB (Becker et al., 1995; Mackey et al., 1996). 


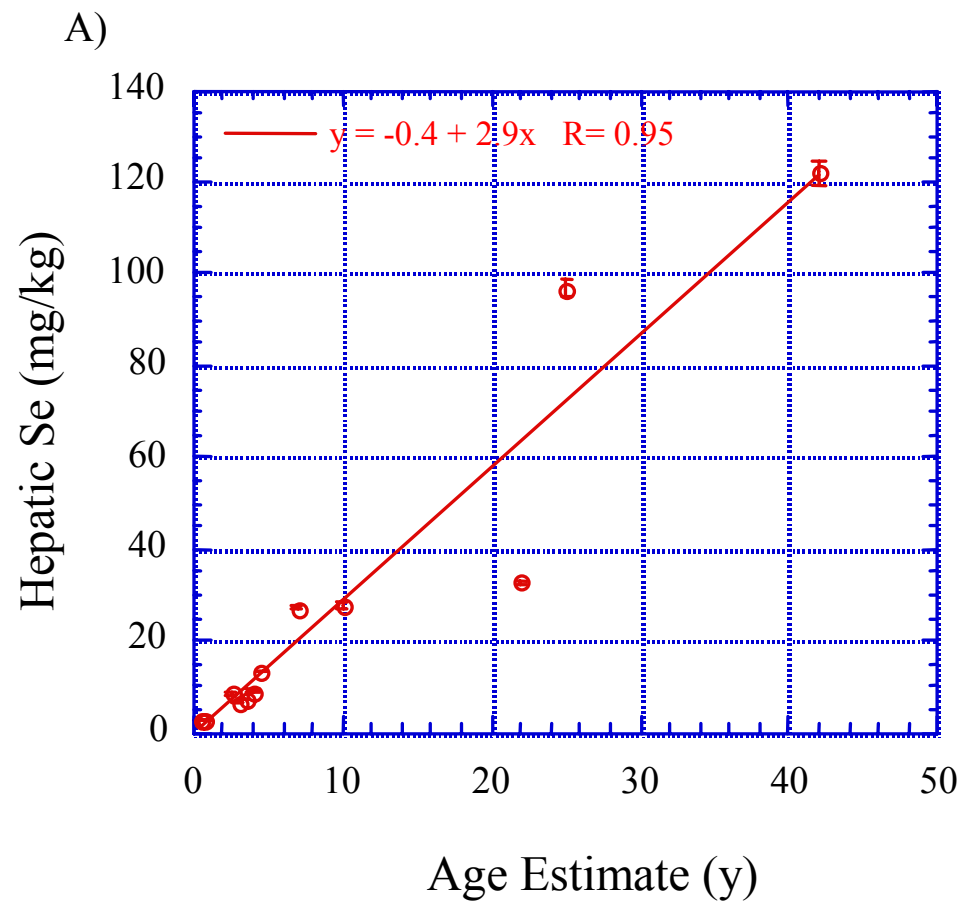

B)

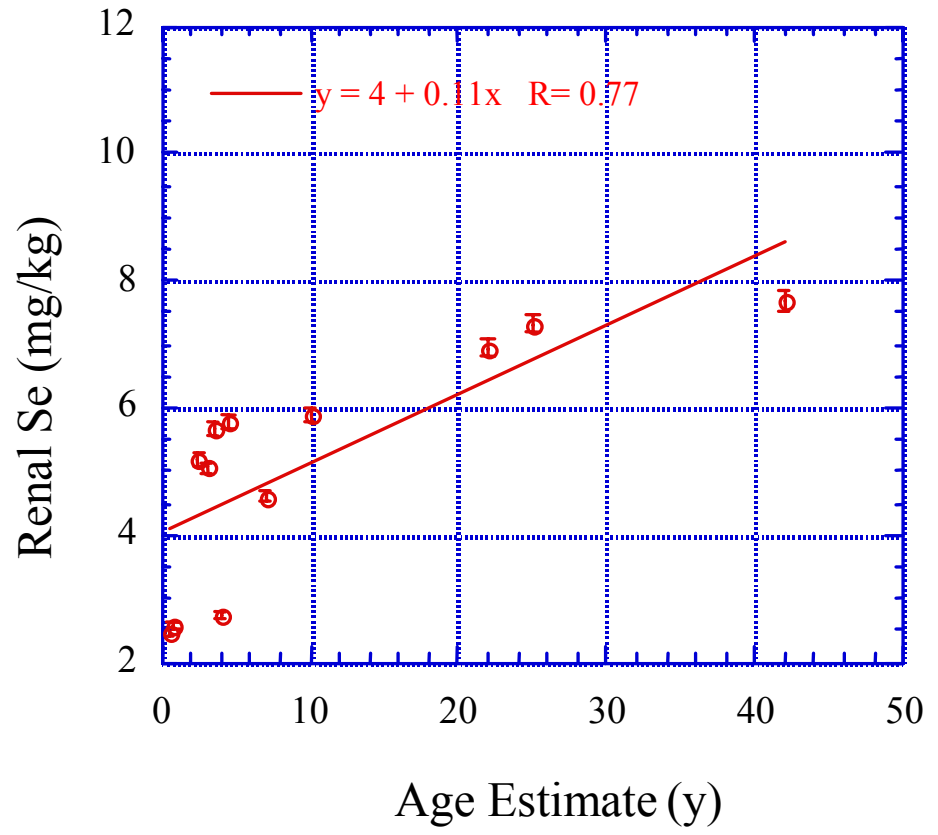

Figure 4: Hepatic (A) and renal (B) Se concentrations $(\mathrm{mg} / \mathrm{kg})$ as a function of rough-toothed dolphin age estimate $(\mathrm{y})$. 


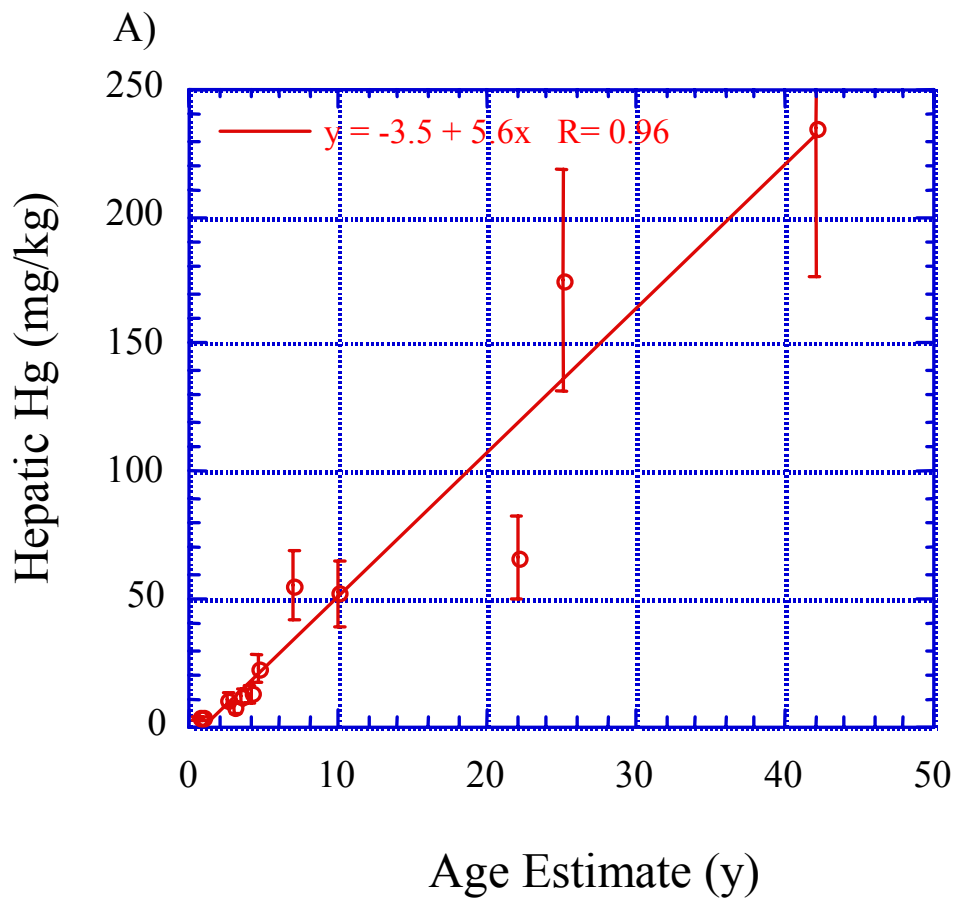

B)

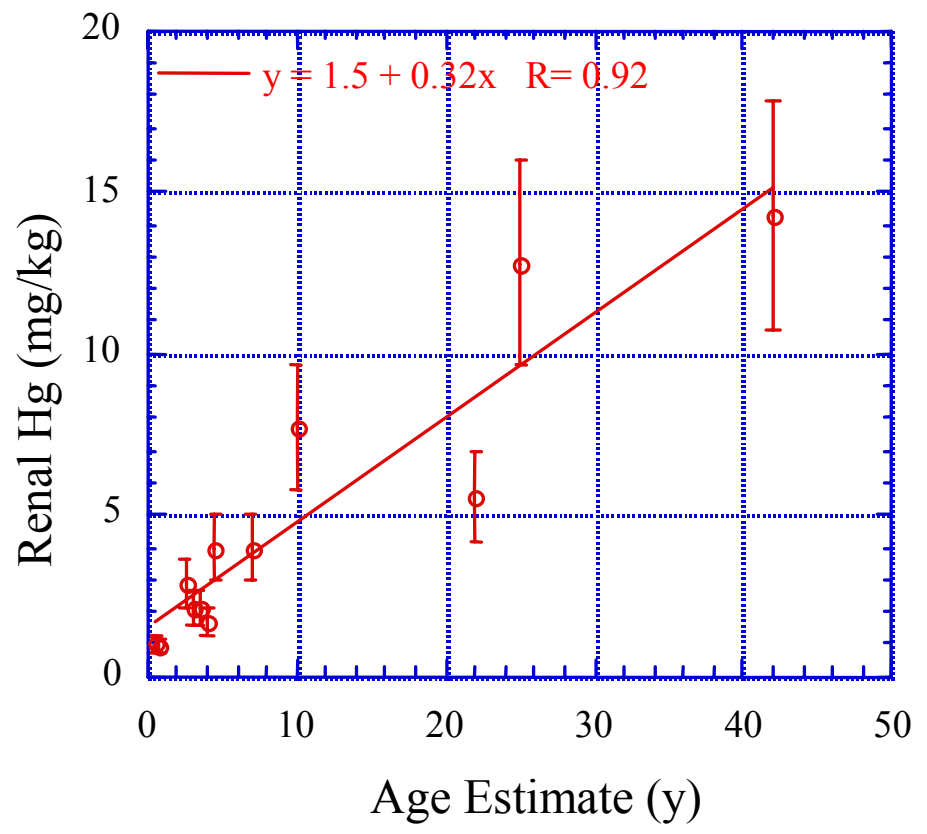

Figure 5: Hepatic (A) and renal (B) $\mathrm{Hg}$ concentrations $(\mathrm{mg} / \mathrm{kg}$ ) as a function of rough-toothed dolphin age estimate (y). 


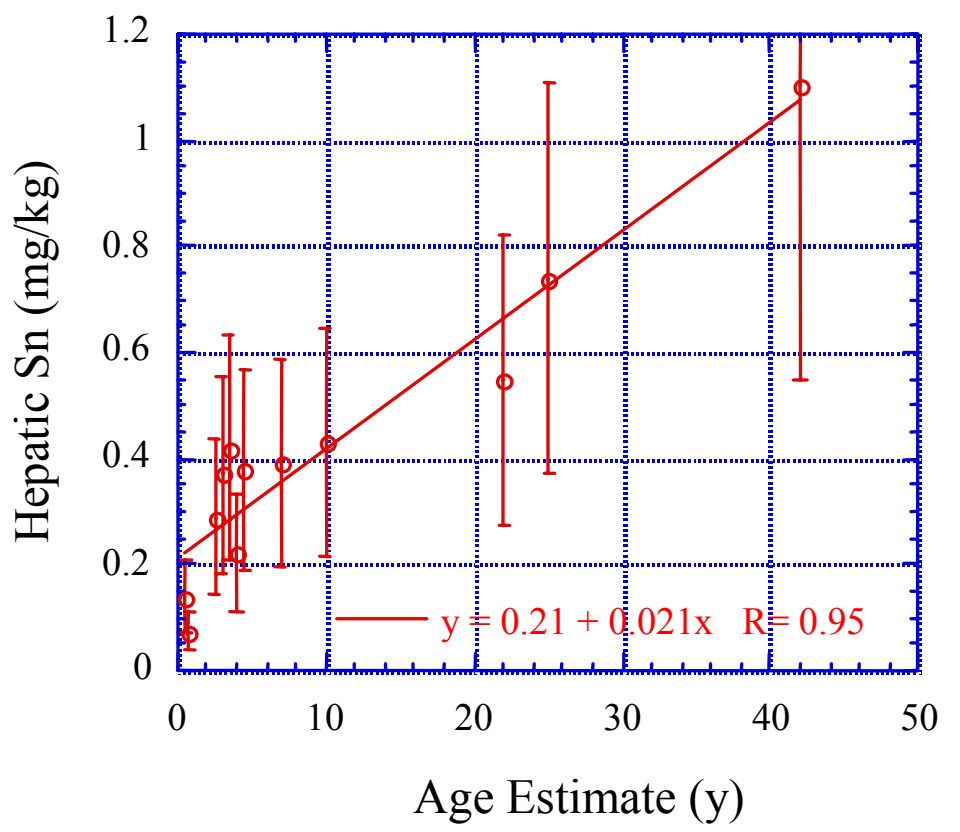

Figure 6: Hepatic Sn concentrations $(\mathrm{mg} / \mathrm{kg})$ as a function of rough-toothed dolphin age estimate (y).

Element Correlations: Data were analyzed to determine whether concentrations of any elements were correlated (Tables B7 and B8). Positive linear correlations were observed for $\mathrm{Na}: \mathrm{Cl}$; Se:Ag; Hg:Se; Ag:Hg; Hg:Sn; and Se:Sn in liver tissue, and for Se:Hg in kidney. Since $\mathrm{Se}, \mathrm{Ag}, \mathrm{Sn}$, and $\mathrm{Hg}$ were found to increase with animal age, it is possible that there were no direct biochemical relationships between these elements, but simply that they all increased with age. The correlation of $\mathrm{Na}$ and $\mathrm{Cl}$ may reflect electrolyte balance. Positive linear correlation relationships were also observed for $\mathrm{Mn}: \mathrm{Zn}$ and $\mathrm{Rb}: \mathrm{K}$ in kidney tissues.

\section{CONCLUSIONS}

This study has documented persistent organic pollutant (POP) and element concentrations in a pelagic species for which little data of this kind are otherwise available. Levels of the POP compounds discussed above were similar to or lower than those found in other species of odontecetes from the Gulf of Mexico as well as other geographical locations (Kuehl et al., 1991; Kuehl and Haebler; 1995, Prudente et al., 1997; and Salata et al., 1995). However, the roughtoothed dolphins had higher percentage ratios of $4,4^{\prime}$-DDT to $4,4^{\prime}$-DDT $+4,4^{\prime}$-DDE than those measured in bottlenose dolphins from the Gulf of Mexico, suggesting higher exposure to currentuse DDTs. Differences in mirex concentrations between rough-toothed dolphins and bottlenose dolphins from the Gulf of Mexico versus bottlenose dolphins from the western Atlantic may prove useful in discriminating between stocks of rough-toothed dolphins from the two regions. Of particular concern were the relatively high concentrations of POPs in the immature dolphins. 
The contaminant concentrations versus age structure suggests that there is substantial off-loading of females' body burdens to their calves, which is of concern, as little is known about the potential negative effects on individual animals and population levels.

Element contents of liver and kidney tissues are, in general, consistent with levels found in other odontocetae. Levels of Se and $\mathrm{Hg}$ in liver tissues were among some of the higher values found in marine mammal tissues from the NBSB, but were similar to those reported for several other species of odontocetae. The elements $\mathrm{Se}, \mathrm{Ag}, \mathrm{Sn}$, and $\mathrm{Hg}$ accumulate in rough-toothed dolphin liver with age. Results also indicate that $\mathrm{Se}$ and $\mathrm{Hg}$ accumulate in rough-toothed dolphin kidney. These findings may reflect the protective mechanism of $\mathrm{Se}$ in detoxification or removal of $\mathrm{Hg}$ in these tissues. Levels of hepatic $\mathrm{Hg}$ and $\mathrm{Se}$ were higher in the rough-toothed dolphins with $\mathrm{Ca}$ inhomogeneity and higher lipid content in the kidney. Additional study is required to determine the significance of this finding.

The mortality event of rough-toothed dolphins in 1997 provided a limited sample set from which much can be learned, but there are still many unanswered questions: e.g., What are contaminant levels in older adult males? How do levels and contaminant profiles from Atlantic rough-toothed dolphins compare with those for rough-toothed dolphins from the Gulf of Mexico? Unfortunately, to address these questions, researchers are dependent on mass-mortality events from which to obtain samples. The MMHSRP administered by NOAA provides the support and coordination for a systematic investigation of mass stranding events and for collection and banking of tissues from these animals so that researchers will have the opportunity to address these questions in the event of future rough-toothed dolphin stranding events.

\section{REFERENCES}

Addison, R. F.; Brodie, P. F. Can. J. Fish. Aquat. Sci. 1987, 44, 782.

Andre, J.; Boudou A.; Ribeyre, F.; Bernhard M. Sci. Total Environ. 1991, 104, 191.

Becker, P. R.; Pugh, R. S.; Schantz, M. M.; Mackey, E. A.; Demiralp, R.; Epstein, M. S.; Donais, M. K.; Porter, B. J.; Wise, S. A.; Mahoney, B. A. NISTIR 6702. U.S. Dept of Commerce. NIST, Gaithersburg, MD, 2001.

Becker, P. R.; Porter B. J.; Mackey, E. A.; Schantz, M. M.; Demiralp, R.; Wise, S. A. NISTIR 6279. U.S. Dept of Commerce. NIST, Gaithersburg, MD, 1999.

Becker, P. R.; Mackey, E.A.; Demiralp, R.; Suydam, R.; Early, G.; B. J. Koster, B. J.; Wise, S. A. Mar. Pollut. Bull. 1995, 30, 262.

Bidleman, T. F.; Alegria, H.; Ngabe, B; Green, C. Atmos. Environ. 1998, 32,1849.

Blaylock, R. A.; Hain, J. W.; Hansen, L. J.; Palka, D. L.; Waring, G. T. NOAA Tech Memo, Miami, FL. NMFS-SEFSC-363, 211 pp. 1995. 
Clark, M. R. In: Research on Dolphins (eds. M.M. Bryden and R.J. Harrison), pp. 281-321. Claredon Press, Oxford, 1986.

Cockroft, V. G.; De Kock, A. C.; Lord, D. A.; Ross, G. J. B. S. Afr. J. Mar. Sci. 1989, 8, 207.

Cockroft, V. G.; De Kock, A. C.; Ross G. J. B.; Lord. D. A. S. Afr. Tydskr. Dierk. 1990, 25, 144.

Davidson, R. M.; Dhekne, R. D.; Moore, W. H.; Butler, D. B. Clin. Nucl. Med. 1990, 15, 692.

Frost D. V.; Lish, P. M. Annu. Rev. Pharmacol. 1975, 15, 259.

Hammond P. B.; Beliles, R .P. In: Casarett and Doull's Toxicology: the Basic Science of Poisons, $2^{\text {nd }}$ ed. (J. Doull, C. D. Klaassen and M. O. Amdur, eds.) Macmillan, New York. pp. 409-467, 1980.

Hansen, C. T.; Nielsen, C. O.; Dietz, R.; Hansen, M. M. Polar Biol. 1990, 10, 529.

Hohn, A. A.; Scott, M. D.; Wells, R. S.; Sweeney, J. C.; Irvine, A. B. Mar. Mam. Sci. 1989, 5, 315.

Holden, A. V.; Mardsen, K. Nature 1967, 216, 1274.

Iwata, H.; Tanabe, S.; Sakai, N.; Tatsukawa, R. Environ. Sci. Technol. 1993, 27, 1080.

Jensen, S. New Scientist 1966, 32, 612.

Julshamn, K.; Andserson, A.; Ringdal, O.; Morkore, J. Sci Total Environ. 1987, 65, 53.

Kannan, K.; Blankenship, A.; Jones, P.; Giesy, J. Human Ecol. Risk Assess. 2000, 6,181.

Kannan, K.; Tanabe, S.; Borrell, A.; Aguilar, A.; Focardi, S.; Tatsukawa. R. Arch. Environ. Contam. Toxicol. 1993, 25, 227.

Koeman, J. H.; de Ven, W. M.; deGoeij, J. J. M.; Tijoe, P.S.; van Haaftten J. L. Sci. Total Environ. 1975, 3, 279.

Kucklick, J. R.; Struntz, D. J.; Becker, P. R.; York, G. W.; O’Hara, T. M.; Bohonowych, J. E. Sci. Total Environ. (In press), 2001.

Kuehl, D. W.; Haebler, R.; Potter, C. Chemosphere, 1991, 22, 1071.

Kuehl, D. W.; Haebler, R. Arch. Environ. Contam. Toxicol. 1995, $28,494$.

Lahvis, G. P.; Wells, R. S.; Kuehl, D. W.; Stewart, J. L.; Rhinehart, H. L; Via C. S. Environ. Health Perspect. 1995, 103, 67. 
Law, R. J. (complier) Collaborative UK Marine Mammal Project: summary of data produced 1988-1992. Fisheries Research Technical Report No. 97.42 pp. 1994.

Law, R. J.; Jones, B. R. Baker, J. R.; Kennedy, S.; Milne R.; Morris R. J. Marine Pollut. Bull. 1992, 24, 296.

Law, R.; Allchin, J.; Jones, B.; Jepson, P.; Baker, J.; Spurrier, C. Marine Pollut. Bull. 1997, 34, 208.

Law R. J.; Blake, S. J.; Jones B. R.; Rogan E. Marine Pollut Bull. 1998, 36, 241.

Layne, J. L. Bull. Fla State Mus. Biol. Sci. 1965, 9,131.

Leatherwood, S.; Reeves, R. R.; Perrin, W. F.; Evans W. E. NOAA Tech. Rep. NMFS Circ. 444, 245 pp. 1982

Lopez-Carrillo, L.; Torres-Arreola, L.; Espinosa-Torres, F.; Jimenez, C.; Cebrian, M.; Waliszewski, S.; Saldate, O. Environ. Health Perspect. 1996, 104, 584.

Mackey, E. A.; Demiralp, R.; Becker, P. R.; Greenberg, R. R.; Koster, B. J.; Wise, S. A. Sci. Tot. Env. 1995, 175, 25.

Mackey, E. A.; Becker, P. R; Demiralp, R.; Greenberg, R. R; Koster, B. J.; Wise. S. A. Arch. Contam. Toxicol. 1996, 30, 503.

Meador, J. P.; Varanasi, U.; Robisch, P. A.; chan S-L. Canadian J. Fish. Aquatic Sci. 1993, 50, 2698,

Marine Mammal Commission. Proceedings of the Marine Mammal Commission Workshop, Keystone, Colorado, 12-15 October, 1998. 150 pp. + vii. 1999.

Marsili, L.; Focardi, S. Environ. Monit. Assess. 1997, 41, 129.

Martoja, R.;Viale, D. CRC Acad. Sci. Paris, 1977, 285, 109.

Miyazaki, N.; Perrin, W. F. In: Handbook of Marine Mammals, Volume 5 The First Book of Dolphins (Eds S.H. Ridgway and F.R.S. Harrison). pp. 1-21 Academic Press. London. 1994.

Muir, D. C. G.; Norstrom, R. J.; Simon, M. Environ. Sci. Tech. 1988, 22, 1071.

Muir, D.; Braune, B.; De March, B.; Norstrom, R.; Wagemann, R.; Lockhart, L.; Hargrave, B.; Bright, D.; Addison, R.; Payne J.; Reimer K.; Sci. Total. Environ. 1999, 230, 83.

Myrick, A. C.; Hohn, A. A.; Sloan, P. A.; Kimura, M.; Stanley, D. D. NOAA Technical Memorandum. Southwest Fisheries Center, National Marine Fisheries Service. Report number NOAA-TM-NMFS-SWFC-30. La Jolla, CA. 17 pp. 1983. 
O’Shea, T. J.; Brownell, R. L. Jr.; Clark, D. R.; Walker, W. A.; Gay, M. L.; Lamont T. G. Pest. Monit. J. 1980, 14, 35.

Perrin, W. F.; Myrick, A. C. (eds.). International Whaling Commission. Special Issue 3. Cambridge. 1980.

Prudente, M.; Tanabe, S.; Watanabe, M.; Subramnian, A.; Miyazaki, N.; Suarez, P.; Tatsukawa. R. Mar. Environ. Res. 1997, 44, 415.

Safe, S. CRC Crit. Rev. Toxicol. 1990, 21, 51.

Salata, G. G.; Wade, T. L.; Sericano, J. L.; Davis, J. W.; Brooks J. M. Environ. Pollut. 1995, 88, 167.

Selye H. J. Urol. 86, 687, 1961

Smith, J. H.; Mabey, W.R.; Bohonos, N.; Holt, B. R.; Lee, S. S.; Chou, T. W.; Bomberger, D. C.; Mill, T. EPA Report EPA-600/7-78-074, 1978

Stegeman, J. J., Hahn. M. E. In: Aquatic Toxicology: Molecular, Biochemical, and Cellular Perspectives (Eds D.C. Malins and G.K. Ostrander), pp. 87-205. CRC Press, Boca Raton. 1994.

Tanabe, S. J. Oceanographic Soc. Japan, 1985, 41, 358.

Tanabe, S.; Iwata, H.; Tatsukawa, R. Sci. Total. Environ. 1994, 154, 163.

Wise, S. A.; Schantz, M. M.; Koster, B. J.; Demiralp, R.; Mackey, E. A.; Greenberg, R. R.; Burow, M.; Ostapczuk, P.; Lillestolen, T. I. Fresenius J. Anal. Chem. 1993, 345, 270.

Zeisler, R.; Langland J. K.; Harrison, S. H. Anal. Chem. 1983, 55, 2431. 
APPENDIX A: Persistent ORganochlorine Compounds: Analytical Data 
Table A1: Organochlorines in SRM 1945 determined by NIST Gaithersburg and NIST Charleston ( $\mathrm{n}=3$ each). Percent difference is the difference between the certified or reference (bold) values ((measured value - certified value/certified value $) * 100)$.

\begin{tabular}{|c|c|c|c|c|c|c|c|c|}
\hline \multirow[t]{2}{*}{ Compound } & \multicolumn{3}{|c|}{ Gaithersburg } & \multicolumn{3}{|c|}{ Charleston } & \multicolumn{2}{|l|}{ Certified or } \\
\hline & Mean & $1 \mathrm{SD}$ & $\%$ Diff & Mean & $1 \mathrm{SD}$ & $\%$ Diff & Reference Values & $95 \%$ CL \\
\hline \begin{tabular}{|l|} 
PCB 18 \\
\end{tabular} & 4.62 & 0.2 & 3 & 4.68 & 0.4 & 5 & 4.48 & 0.88 \\
\hline РCB 31 & 3.34 & 0.1 & 7 & 3.72 & 0.1 & 19 & 3.12 & 0.69 \\
\hline PCB 28 & 12.3 & 0.4 & -13 & 10.0 & 0.2 & -29 & 14.1 & 1.4 \\
\hline PCB 52 & 39.9 & 0.9 & -8 & 35.9 & 0.4 & -18 & 43.6 & 2.5 \\
\hline PCB 49 & 18.4 & 0.4 & -11 & 16.1 & 0.3 & -22 & 20.8 & 2.8 \\
\hline PCB 44 & 12.3 & 0.2 & 1 & 11.6 & 0.3 & -5 & 12.2 & 1.4 \\
\hline РCB 66 & 24.7 & 1.0 & 5 & 29.5 & 1.4 & 25 & 23.6 & 1.6 \\
\hline РCB 95 & 35.0 & 1.0 & 4 & 32.7 & 0.6 & -3 & 33.8 & 1.7 \\
\hline PCB 101+90 & 67.9 & 2.2 & 4 & 81.0 & 1.7 & 24 & 65.2 & 5.6 \\
\hline PCB 99 & 50.6 & 0.7 & 11 & 51.4 & 0.9 & 13 & 45.4 & 5.4 \\
\hline PCB 87 & 16.6 & 0.2 & -1 & 22.4 & 0.9 & 34 & 16.7 & 1.4 \\
\hline PCB 118 & 74.3 & 0.6 & -0.4 & 74.1 & 2.0 & -0.7 & 74.6 & 5.1 \\
\hline PCB 105 & 29.7 & 1.4 & -1 & 22.1 & 0.8 & -27 & 30.1 & 2.3 \\
\hline PCB 151+82 & 28.3 & 0.9 & -2 & 26.2 & 1.6 & -9 & 28.7 & 5.2 \\
\hline PCB 149 & 82.8 & 4.2 & -22 & 74.9 & 2.3 & -30 & 106.6 & 8.4 \\
\hline PCB 153 & 225 & 3.0 & 6 & 231 & 7.8 & 9 & 213 & 19 \\
\hline PCB 138 & 133 & 2.1 & 1 & 113 & 7.6 & -14 & 131.5 & 7.4 \\
\hline PCB 128 & 22.9 & 0.5 & -3 & 20.4 & 1.7 & -14 & 23.7 & 1.7 \\
\hline PCB 156 & 10.1 & 0.3 & -2 & 10.1 & 0.3 & -2 & 10.3 & 1.1 \\
\hline PCB 187 & 111 & 2.5 & 5 & 101 & 3.6 & -4 & 105.1 & 9.1 \\
\hline PCB 183 & 35.8 & 0.3 & -2 & 34.4 & 1.3 & -6 & 36.6 & 4.1 \\
\hline PCB 180 & 123 & 1.0 & 15 & 129 & 4.8 & 21 & 106.7 & 5.3 \\
\hline PCB 170 & 42.3 & 0.7 & 4 & 33.5 & 1.2 & -17 & 40.6 & 2.6 \\
\hline PCB 201 & 16.8 & 0.4 & -1 & 24.0 & 0.6 & 42 & 16.96 & 0.89 \\
\hline PCB 195 & 16.8 & 0.2 & -5 & 19.5 & 0.7 & 10 & 17.7 & 4.3 \\
\hline PCB 194 & 47.6 & 4.1 & 20 & 58.2 & 2.6 & 47 & 39.6 & 2.5 \\
\hline PCB 206 & 36.6 & 1.4 & 18 & 44.5 & 2.1 & 43 & 31.1 & 2.7 \\
\hline PCB 209 & 15.4 & 0.3 & 45 & 18.4 & 0.6 & 74 & 10.6 & 1.1 \\
\hline $\mathrm{HCB}$ & 31.7 & 1.0 & -4 & 27.1 & 0.5 & -18 & 32.9 & 1.7 \\
\hline$\alpha-\mathrm{HCH}$ & 16.4 & 0.6 & 1 & 15.5 & 0.6 & -4 & 16.2 & 3.4 \\
\hline$\beta-\mathrm{HCH}$ & 8.40 & 0.4 & 5 & 3.87 & 0.3 & -52 & 8.00 & 1.4 \\
\hline$\gamma-\mathrm{HCH}$ & 3.19 & 0.1 & -3 & 3.09 & 0.1 & -6 & 3.3 & 0.81 \\
\hline oxychlordane & 20.2 & 0.4 & 2 & 20.8 & 0.7 & 5 & 19.8 & 1.9 \\
\hline heptachlor epoxide & 10.4 & 0.4 & -4 & 9.56 & 0.3 & -11 & 10.8 & 1.3 \\
\hline $2,4^{\prime}-\mathrm{DDE}$ & 12.2 & 0.5 & -1 & 10.5 & 0.2 & -15 & 12.3 & 0.87 \\
\hline 4,4'-DDE & 468 & 9.0 & 5 & 556 & 7.5 & 25 & 445 & 37 \\
\hline trans-chlordane & 10.9 & 0.3 & -- & 10.6 & 0.4 & -- & -- & -- \\
\hline cis-chlordane & 47.4 & 1.0 & 1 & 53.4 & 1.2 & 14 & 46.9 & 2.8 \\
\hline trans-nonachlor & 218 & 3.5 & -6 & 189 & 2.4 & -18 & 231 & 11 \\
\hline cis-nonachlor & 49.0 & 0.7 & 1 & 48.8 & 1.4 & 0 & 48.7 & 7.6 \\
\hline 2,4'-DDD & 19.2 & 0.6 & 6 & 19.5 & 1.5 & 8 & 18.1 & 2.8 \\
\hline 4,4'-DDD & 130 & 6.1 & -3 & 127 & 3.0 & -5 & 133 & 10 \\
\hline $2,4^{\prime}$-DDT & 95.8 & 5.0 & -10 & 73.4 & 6.6 & -31 & 106 & 14 \\
\hline 4,4'-DDT & 241 & 5.5 & -1 & 222 & 4.1 & -9 & 245 & 15 \\
\hline dieldrin & 40.0 & 0.4 & 7 & 51.0 & 1.9 & 36 & 37.5 & 3.9 \\
\hline mirex & 29.8 & 0.6 & 57 & 35.1 & 1.3 & 86 & 18.9 & 2.8 \\
\hline$\%$ lipid & 73.9 & 0.2 & 0 & 70.1 & 0.1 & -6 & 74.3 & 0.45 \\
\hline
\end{tabular}


Table A2: Results of paired PCB and organochlorine pesticides analyses made by NIST Gaithersburg and Charleston laboratories. Values are $\mathrm{ng} / \mathrm{g}$ wet mass.

\begin{tabular}{|c|c|c|c|c|c|c|c|c|c|}
\hline \multirow[t]{2}{*}{ Compound } & \multicolumn{3}{|c|}{ RTDL-001 } & \multicolumn{3}{|c|}{ RTDL-002 } & \multicolumn{3}{|c|}{ RTDL-003 } \\
\hline & Gaithersburg & Charleston & Diff. (\%) & Gaithersburg & Charleston & Diff. (\%) & Gaithersburg & Charleston & Diff. (\%) \\
\hline PCB 8 & 5.81 & 7.43 & 24 & $<2$ & 2.73 & -- & 2.33 & 2.31 & 1 \\
\hline PCB 18 & 10.7 & 8.23 & 26 & 9.53 & 18.1 & 62 & 2.65 & 1.03 & 88 \\
\hline PCB 31 & 19.7 & $<1$ & -- & 8.24 & 6.44 & 25 & 1.41 & $<1$ & -- \\
\hline PCB 28 & w/ PCB 31 & 23.1 & -- & 3.68 & $<1$ & -- & 1.79 & 2.41 & 30 \\
\hline PCB 52 & 185 & 205 & 10 & 103 & 111 & 7 & 1.81 & 1.43 & 23 \\
\hline PCB 49 & 180 & 166 & 8 & 51.8 & 51.9 & 0 & 1.19 & $<1$ & -- \\
\hline PCB 44 & 48.2 & 65.4 & 30 & 15.8 & 17.2 & 8 & 2.57 & 2.59 & 1 \\
\hline PCB 66 & 238 & 293 & 21 & 82.3 & 82 & 0 & 6.53 & 7.9 & 19 \\
\hline PCB 95 & 355 & 345 & 3 & 147 & 167 & 13 & 9.53 & 9.65 & 1 \\
\hline PCB 101+90 & 2230 & 2778 & 22 & 416 & 484 & 15 & 32.5 & 44.5 & 31 \\
\hline PCB 99 & 1229 & 1160 & 6 & 659 & 706 & 7 & 28.4 & 45.6 & 46 \\
\hline PCB 87 & 282 & 269 & 5 & 87.5 & 103 & 16 & 13.0 & 11.4 & 13 \\
\hline PCB 110 & 182 & 189 & 4 & 26.3 & 10.7 & 84 & 13.9 & 12.1 & 14 \\
\hline PCB 118 & 1170 & 1220 & 4 & 466 & 573 & 21 & 28.2 & 35.5 & 23 \\
\hline PCB 105 & 285 & 302 & 6 & 87.1 & 119 & 31 & 4.91 & 8.21 & 50 \\
\hline PCB $151+82$ & 544 & 599 & 10 & 293 & 392 & 29 & 19.6 & 20.9 & 6 \\
\hline PCB 149 & 1398 & 1353 & 3 & 634 & 857 & 30 & 38.7 & 50.5 & 26 \\
\hline PCB 153 & 6365 & 5881 & 8 & 3774 & 4795 & 24 & 180 & 247 & 31 \\
\hline PCB 138 & 3645 & 2917 & 22 & 2642 & 2402 & 10 & 118 & 109 & 8 \\
\hline PCB 128 & 552 & 512 & 8 & 228 & 321 & 34 & 21.2 & 18.3 & 15 \\
\hline PCB 156 & 151 & 153 & 1 & 36.8 & 41.7 & 12 & 7.01 & 7.22 & 3 \\
\hline PCB 187 & 2399 & 2301 & 4 & 1531 & 2060 & 29 & 114 & 126 & 10 \\
\hline PCB 183 & 628 & 609 & 3 & 528 & 586 & 10 & 31.1 & 33.9 & 9 \\
\hline PCB 180 & 2015 & 1969 & 2 & 1651 & 2020 & 20 & 84.3 & 111 & 27 \\
\hline PCB 170 & 659 & 632 & 4 & 610 & 604 & 1 & 30.2 & 32.9 & 9 \\
\hline PCB 201 & 324 & 369 & 13 & 214 & 315 & 38 & 18.9 & 20.3 & 7 \\
\hline PCB 195 & 87.3 & 134 & 42 & 63.4 & 115 & 58 & 15.4 & 16.0 & 4 \\
\hline PCB 194 & 297 & 309 & 4 & 277 & 363 & 27 & 35.7 & 35.8 & 0 \\
\hline PCB 206 & 173 & 165 & 5 & 144 & 189 & 27 & 35.9 & 38.4 & 7 \\
\hline PCB 209 & 37.8 & 35.6 & 6 & 44.6 & 49.7 & 11 & 26.8 & 22.6 & 17 \\
\hline $\mathrm{HCB}$ & 44.2 & 46.4 & 5 & 8.99 & 9.86 & 9 & $<2$ & $<1$ & -- \\
\hline$\alpha-\mathrm{HCH}$ & 50.6 & 53.9 & 6 & $<2$ & 1.59 & -- & $<2$ & $<1$ & -- \\
\hline$\beta-\mathrm{HCH}$ & 115 & 109 & 5 & 4.45 & 5.11 & 14 & $<2$ & 0 & -- \\
\hline$\gamma-\mathrm{HCH}$ & 13.4 & 14.3 & 6 & $<2$ & $<1$ & -- & $<2$ & 5.09 & -- \\
\hline oxychlordane & 161 & 151 & 6 & 89.6 & 97.2 & 8 & 3.65 & 4.29 & 16 \\
\hline heptachlor epoxide & 285 & 328 & 14 & 35.4 & 46.2 & 26 & $<2$ & $<1$ & -- \\
\hline $2,4^{\prime}-\mathrm{DDE}$ & 144 & 149 & 3 & 56.7 & 51.9 & 9 & 3.74 & 3.99 & 6 \\
\hline 4,4'-DDE & 10996 & 11337 & 3 & 5822 & 5950 & 2 & 225 & 217 & 4 \\
\hline trans-chlordane & 91.5 & 60.7 & 40 & 9.56 & $<1$ & -- & $<2$ & 0.38 & -- \\
\hline cis-chlordane & 806 & 822 & 2 & 33.6 & 37.8 & 12 & 17.5 & 16.9 & 3 \\
\hline trans-nonachlor & 4923 & 5092 & 3 & 992 & 1079 & 8 & 38.4 & 39.1 & 2 \\
\hline cis-nonachlor & 1877 & 1909 & 2 & 187 & 196 & 5 & 16.4 & 15.1 & 8 \\
\hline 2,4'-DDD & 201 & 219 & 9 & 26.5 & 29.8 & 12 & $<2$ & $<1$ & -- \\
\hline 4,4'-DDD & 4481 & 4561 & 2 & 342 & 362 & 6 & 41.8 & 36.8 & 13 \\
\hline 2,4'-DDT & 443 & 406 & 9 & 299 & 305 & 2 & 10.7 & 12.3 & 14 \\
\hline 4,4'-DDT & 6682 & 6895 & 3 & 666 & 675 & 1 & 25.8 & 27.7 & 7 \\
\hline dieldrin & 1233 & 1213 & 2 & 90.4 & 91.9 & 2 & 17.4 & 19.0 & 9 \\
\hline mirex & 265 & 296 & 11 & 246 & 252 & 2 & 17.2 & 18.6 & 8 \\
\hline$\%$ lipid & 67.0 & 66.3 & 1 & 46.2 & 44.4 & 4 & 39.8 & 38.0 & 5 \\
\hline
\end{tabular}


Table A2: Continued

\begin{tabular}{|c|c|c|c|c|c|c|c|c|c|}
\hline \multirow[t]{2}{*}{ Compound } & \multicolumn{3}{|c|}{ RTDL-004 } & \multicolumn{3}{|c|}{ RTDL-005 } & \multicolumn{3}{|c|}{ RTDL-006 } \\
\hline & Gaithersburg & Charleston & Diff. (\%) & Gaithersburg & Charleston & Diff. (\%) & Gaithersburg & Charleston & Diff. (\%) \\
\hline PCB 8 & 3.17 & 9.60 & 101 & 6.04 & 5.78 & 4 & 3.02 & 3.15 & 4 \\
\hline PCB 18 & 6.26 & 55.9 & 159 & 6.01 & 30.0 & 133 & 9.17 & 42.2 & 128 \\
\hline PCB 31 & 6.63 & 5.10 & 26 & 3.23 & 2.53 & 24 & 9.33 & $<1$ & -- \\
\hline PCB 28 & 10.4 & 17.0 & 48 & 5.85 & 8.22 & 34 & w/ PCB 31 & 9.75 & -- \\
\hline PCB 52 & 263 & 331 & 23 & 127 & 148 & 15 & 179 & 168 & 6 \\
\hline PCB 49 & 143 & 170 & 17 & 52.6 & 64.2 & 20 & 125 & 97.5 & 25 \\
\hline PCB 44 & 29.6 & 56.4 & 62 & 9.73 & 24.8 & 87 & 23.5 & 33.0 & 34 \\
\hline PCB 66 & 276 & 267 & 3 & 92 & 115 & 22 & 104 & 126 & 19 \\
\hline PCB 95 & 409 & 551 & 30 & 191 & 235 & 21 & 250 & 265 & 6 \\
\hline PCB $101+90$ & 972 & 1328 & 31 & 402 & 526 & 27 & 828 & 887 & 7 \\
\hline РCB 99 & 1596 & 2081 & 26 & 1120 & 1301 & 15 & 1091 & 858 & 24 \\
\hline PCB 87 & 275 & 284 & 3 & 105 & 127 & 19 & 140 & 76.2 & 59 \\
\hline PCB 110 & 86.3 & 104 & 19 & 31.6 & 38.4 & 19 & 35.5 & 43.5 & 20 \\
\hline PCB 118 & 1124 & 1428 & 24 & 456 & 595 & 26 & 759 & 652 & 15 \\
\hline PCB 105 & 228 & 306 & 29 & 82.9 & 113 & 31 & 167 & 151 & 10 \\
\hline PCB $151+82$ & 1026 & 1155 & 12 & 534 & 638 & 18 & 418 & 416 & 0 \\
\hline PCB 149 & 2319 & 2578 & 11 & 1122 & 1408 & 23 & 1090 & 982 & 10 \\
\hline PCB 153 & 8961 & 12778 & 35 & 8961 & 9202 & 3 & 5292 & 4413 & 18 \\
\hline PCB 138 & 6430 & 6529 & 2 & 4142 & 4622 & 11 & 2989 & 2111 & 34 \\
\hline PCB 128 & 688 & 893 & 26 & 301 & 398 & 28 & 324 & 341 & 5 \\
\hline PCB 156 & 81.1 & 89.3 & 10 & 30.1 & 35.7 & 17 & 49 & 48.8 & 0 \\
\hline PCB 187 & 3439 & 3409 & 1 & 3439 & 3779 & 9 & 1690 & 1759 & 4 \\
\hline PCB 183 & 1738 & 1652 & 5 & 1317 & 1241 & 6 & 560 & 494 & 13 \\
\hline PCB 180 & 4064 & 5446 & 29 & 4064 & 4250 & 4 & 1500 & 1679 & 11 \\
\hline PCB 170 & 1319 & 1685 & 24 & 1319 & 1220 & 8 & 606 & 518 & 16 \\
\hline PCB 201 & 558 & 854 & 42 & 438 & 569 & 26 & 257 & 273 & 6 \\
\hline PCB 195 & 177 & 265 & 40 & 77.8 & 139 & 56 & 77.4 & 111 & 36 \\
\hline PCB 194 & 716 & 893 & 22 & 620 & 732 & 17 & 345 & 320 & 8 \\
\hline PCB 206 & 242 & 309 & 24 & 158 & 186 & 16 & 139 & 155 & 11 \\
\hline PCB 209 & 50.5 & 58.0 & 14 & 53.8 & 63.3 & 16 & 53.8 & 51.4 & 5 \\
\hline $\mathrm{HCB}$ & 43.1 & 46.5 & 8 & 10.2 & 14.1 & 32 & 64.8 & 69.0 & 6 \\
\hline$\alpha-\mathrm{HCH}$ & 4.44 & 5.08 & 13 & $<2$ & 2.41 & -- & $<2$ & 1.80 & -- \\
\hline$\beta-\mathrm{HCH}$ & 19.8 & 21.5 & 8 & 5.45 & 6.72 & 21 & 9.45 & 10.3 & 9 \\
\hline$\gamma-\mathrm{HCH}$ & $<2$ & $<1$ & -- & $<2$ & $<1$ & -- & $<2$ & $<1$ & -- \\
\hline oxychlordane & 285 & 276 & 3 & 124 & 137 & 10 & 121 & 117 & 3 \\
\hline heptachlor epoxide & 55.5 & 129 & 80 & 22.7 & 46.7 & 69 & 25.7 & 51.4 & 67 \\
\hline 2,4'-DDE & 214 & 220 & 3 & 104 & 117 & 12 & 221 & 213 & 4 \\
\hline 4,4'-DDE & 18105 & 17744 & 2 & 15042 & 14809 & 2 & 5687 & 5879 & 3 \\
\hline trans-chlordane & 6.32 & 5.27 & 18 & 9.87 & $<1$ & -- & 10.1 & $<1$ & -- \\
\hline cis-chlordane & 122 & 129 & 6 & 39.4 & 38.6 & 2 & 35.6 & 39.9 & 11 \\
\hline trans-nonachlor & 3444 & 3510 & 2 & 2145 & 2029 & 6 & 785 & 755 & 4 \\
\hline cis-nonachlor & 651 & 625 & 4 & 201 & 210 & 4 & 205 & 213 & 4 \\
\hline 2,4'-DDD & 74.6 & 70.9 & 5 & 58.3 & 59.5 & 2 & 46.9 & 47.6 & 1 \\
\hline 4,4'-DDD & 951 & 937 & 1 & 315 & 323 & 3 & 524 & 553 & 5 \\
\hline 2,4'-DDT & 597 & 575 & 4 & 398 & 441 & 10 & 222 & 248 & 11 \\
\hline 4,4'-DDT & 1256 & 1311 & 4 & 451 & 449 & 0 & 625 & 655 & 5 \\
\hline dieldrin & 251 & 297 & 17 & 73.4 & 86.9 & 17 & 141 & 133 & 6 \\
\hline mirex & 666 & 625 & 6 & 466 & 509 & 9 & 274 & 232 & 17 \\
\hline$\%$ lipid & 56.9 & 55.8 & 2 & 43.2 & 42.8 & 1 & 72.1 & 73.3 & 2 \\
\hline
\end{tabular}


Table A3: Concentrations (ng/g lipid mass) of PCB congeners determined in three aliquots of RTDL-004 blubber.

\begin{tabular}{|c|c|c|c|c|c|c|}
\hline PCB Congener & $\mathbf{A}$ & $\frac{\text { RTDL-00 }}{B}$ & C & Mean & $1 \mathrm{SD}^{*}$ & $\%$ RSD \\
\hline PCB 8 & 15.0 & 19.0 & 17.2 & 17.1 & 2.0 & 11.6 \\
\hline PCB 18 & 113 & 95.0 & 93.3 & 100 & 11 & 11.0 \\
\hline PCB 29 & 95.0 & 70.3 & 72.5 & 79.3 & 14 & 17.3 \\
\hline PCB 31 & na** & na & na & -- & -- & -- \\
\hline РCB 28 & 40.1 & 29.7 & 30.5 & 33.4 & 5.8 & 17 \\
\hline PCB 52 & 602 & 579 & 593 & 592 & 12 & 2.0 \\
\hline РCB 49 & 315 & 296 & 305 & 305 & 9.3 & 3.1 \\
\hline PCB 44 & 112 & 103 & 101 & 105 & 5.8 & 5.5 \\
\hline PCB 95 & 883 & 937 & 987 & 936 & 52 & 5.5 \\
\hline PCB 66 & 452 & 463 & 478 & 464 & 13 & 2.9 \\
\hline PCB 101+90 & 2300 & 2330 & 2380 & 2340 & 40 & 1.7 \\
\hline PCB 99 & 3480 & 3500 & 3730 & 3570 & 139 & 3.9 \\
\hline PCB 87 & 441 & 512 & 509 & 487 & 40 & 8.2 \\
\hline PCB 110 & 204 & 186 & 187 & 193 & 10 & 5.3 \\
\hline PCB 151+82 & 1860 & 1930 & 2070 & 1953 & 107 & 5.5 \\
\hline PCB 149 & 4100 & 4380 & 4620 & 4370 & 260 & 6.0 \\
\hline PCB 118 & 2370 & 2470 & 2560 & 2470 & 95 & 3.8 \\
\hline PCB 153 & 21500 & 22400 & 22900 & 22300 & 709 & 3.2 \\
\hline PCB 105 & 530 & 537 & 549 & 539 & 9.8 & 1.8 \\
\hline PCB 138 & 10700 & 11400 & 11700 & 11300 & 513 & 4.5 \\
\hline PCB 187 & 8960 & 9640 & 6110 & 8240 & 1120 & 14 \\
\hline PCB 183 & 2620 & 2900 & 2960 & 2830 & 181 & 6.4 \\
\hline PCB 128 & 1460 & 1580 & 1600 & 1547 & 76 & 4.9 \\
\hline PCB 201 & 1390 & 1500 & 1530 & 1473 & 74 & 5.0 \\
\hline PCB 156 & 180 & 178 & 160 & 173 & 11 & 6.4 \\
\hline PCB 180 & 9090 & 9760 & 9760 & 9540 & 387 & 4.1 \\
\hline PCB 170 & 2730 & 3010 & 3020 & 2920 & 165 & 5.6 \\
\hline PCB 195 & 450 & 462 & 475 & 462 & 12 & 2.7 \\
\hline PCB 194 & 1520 & 1620 & 1600 & 1580 & 53 & 3.3 \\
\hline PCB 206 & 510 & 557 & 553 & 540 & 26 & 4.8 \\
\hline РCB 209 & 102 & 114 & 104 & 107 & 6.0 & 5.6 \\
\hline
\end{tabular}

*Standard deviation

**na $=$ An unknown compound interfered with PCB 31. 
Table A4: Concentrations (ng/g lipid mass) of organochlorine pesticides determined in three aliquots of RTDL-004 blubber homogenate.

\begin{tabular}{|c|c|c|c|c|c|c|}
\hline Compound & $\mathbf{A}$ & $\frac{\text { RTDL-00 }}{B}$ & $\mathbf{C}$ & Mean & $1 \mathrm{SD} *$ & \%RSD \\
\hline$\alpha-H C H$ & 11.5 & 9.88 & 9.10 & 10.2 & 1.2 & 12 \\
\hline$\beta-Н С Н$ & 44.8 & 52.3 & 38.5 & 45.2 & 6.9 & 15 \\
\hline$\gamma-\mathbf{H C H}$ & $<1$ & $<1$ & $<1$ & -- & -- & -- \\
\hline heptachlor & $<1$ & $<1$ & $<1$ & -- & -- & -- \\
\hline heptachlor epoxide & 210 & 222 & 231 & 221 & 11 & 4.8 \\
\hline trans-chlordane & 8.26 & 7.08 & 9.44 & 8.26 & 1.2 & 14 \\
\hline cis-chlordane & 215 & 224 & 231 & 223 & 8.1 & 3.6 \\
\hline trans-nonachlor & 6280 & 5650 & 6290 & 6070 & 367 & 6.0 \\
\hline cis-nonachlor & 1040 & 1030 & 1120 & 1063 & 49 & 4.6 \\
\hline oxychlordane & 553 & 453 & 494 & 500 & 50 & 10 \\
\hline 2,4'-DDE & 375 & 358 & 394 & 376 & 18 & 4.7 \\
\hline $4,4^{\prime}-\mathrm{DDE}$ & 34100 & 30400 & 31800 & 32100 & 1868 & 5.8 \\
\hline $2,4^{\prime}-\mathrm{DDT}$ & 1060 & 941 & 1030 & 1010 & 62 & 6.1 \\
\hline $4,4^{\prime}$-DDT & 2610 & 2260 & 2350 & 2407 & 182 & 7.6 \\
\hline 2,4'-DDD & 126 & 124 & 127 & 126 & 1.3 & 1.0 \\
\hline $4,4^{\prime}$-DDD & 1770 & 1540 & 1680 & 1663 & 116 & 7.0 \\
\hline mirex & 1290 & 1140 & 1120 & 1183 & 93 & 7.8 \\
\hline HCB & 74.3 & 71.5 & 83.4 & 76.4 & 6.2 & 8.2 \\
\hline dieldrin & 559 & 530 & 533 & 541 & 16 & 3.0 \\
\hline Lipid (\%) & 54.9 & 57.5 & 55.0 & 55.8 & 1.50 & 1.3 \\
\hline
\end{tabular}

* Standard Deviation 
Table A5: Concentrations (ng/g lipid mass) of PCB congeners determined in rough-toothed dolphin blubber homogenates. Values for RTDL-001 to -006 are the average of the values determined by the Charleston and Gaithersburg NIST laboratories.

\begin{tabular}{|c|c|c|c|c|c|c|c|c|c|c|c|c|c|c|c|}
\hline \multirow[b]{2}{*}{ Compound } & \multicolumn{6}{|c|}{ Males } & \multicolumn{9}{|c|}{ Females } \\
\hline & $\begin{array}{c}\text { RTDL- } \\
002\end{array}$ & $\begin{array}{c}\text { RTDL- } \\
004\end{array}$ & $\begin{array}{c}\text { RTDL- } \\
005\end{array}$ & $\begin{array}{c}\text { RTDL- } \\
006\end{array}$ & $\begin{array}{c}\text { RTDL- } \\
012\end{array}$ & $\begin{array}{c}\text { RTDL- } \\
014\end{array}$ & $\begin{array}{c}\text { RTDL- } \\
001\end{array}$ & $\begin{array}{c}\text { RTDL- } \\
003\end{array}$ & $\begin{array}{c}\text { RTDL- } \\
007\end{array}$ & $\begin{array}{c}\text { RTDL- } \\
008\end{array}$ & $\begin{array}{c}\text { RTDL } \\
009\end{array}$ & $\begin{array}{c}\text { RTDL - } \\
010\end{array}$ & $\begin{array}{c}\text { RTDL - } \\
011\end{array}$ & $\begin{array}{c}\text { RTDL - } \\
013\end{array}$ & $\begin{array}{c}\text { RTDL - } \\
015\end{array}$ \\
\hline PCB 8 & 6.15 & 11.39 & 13.74 & 4.24 & 7.27 & 8.00 & 9.94 & 5.97 & 7.56 & $<1$ & 2.16 & 7.38 & 7.11 & 2.80 & 6.58 \\
\hline PCB 18 & 40.8 & 55.7 & 42.0 & 35.1 & 31.9 & 42.3 & 14.2 & 4.68 & 185 & 1.20 & 58.1 & 36.9 & 29.8 & 17.8 & 43.2 \\
\hline PCB 29 & 34.5 & 79.2 & 44.6 & 38.9 & 78.0 & 79.8 & 89.6 & 8.54 & 65.6 & $<1$ & 39.1 & 76.9 & 67.6 & 17.5 & 31.9 \\
\hline PCB 31 & 17.8 & 11.7 & 7.48 & 12.9 & $<1$ & $<1$ & $<1$ & 3.54 & $<1$ & $<1$ & $<1$ & $<1$ & $<1$ & $<1$ & 7 \\
\hline PCB 28 & $<1$ & 30.5 & 19.2 & 13.3 & 35.5 & 25.0 & 34.8 & 6.34 & 36.9 & $<1$ & 23.6 & 34.7 & 22.4 & 4.82 & 9.91 \\
\hline PCB 52 & 236 & 528 & 320 & 239 & 300 & 330 & 293 & 4.16 & 413 & 5.28 & 265 & 304 & 281 & 83.2 & 226 \\
\hline РCB 49 & 115 & 278 & 136 & 153 & 249 & 251 & 260 & 2.81 & 120 & 4.32 & 163 & 248 & 215 & 71.4 & 117 \\
\hline PCB 44 & 36.5 & 76.5 & 40.2 & 38.8 & 106 & 101 & 85.3 & 6.64 & 59.6 & $<1$ & 63.2 & 105 & 83.8 & 24.3 & 37.7 \\
\hline PCB 66 & 181 & 482 & 241 & 158 & 452 & 415 & 399 & 18.6 & 86.2 & 9.85 & 221 & 438 & 357 & 119 & 162 \\
\hline РCB 95 & 347 & 853 & 496 & 354 & 508 & 560 & 525 & 24.7 & 570 & 2.91 & 401 & 518 & 496 & 148 & 391 \\
\hline PCB $101+90$ & 995 & 2044 & 1080 & 1179 & 2260 & 2400 & 3759 & 99.4 & 1370 & 47.5 & 1460 & 4260 & 2070 & 541 & 1090 \\
\hline PCB 99 & 1508 & 3267 & 2816 & 1342 & 1730 & 1890 & 1792 & 95.7 & 2300 & 44.4 & 1210 & 1700 & 1640 & 488 & 1360 \\
\hline PCB 87 & 211 & 496 & 270 & 149 & 303 & 301 & 413 & 31.3 & 154 & 4.98 & 143 & 324 & 272 & 117 & 174 \\
\hline PCB 110 & 40.5 & 169 & 81.4 & 54.3 & 340 & 246 & 278 & 33.4 & 91.1 & 17.2 & 95.5 & 324 & 211 & 105 & 34.6 \\
\hline PCB $151+82$ & 1150 & 2267 & 1223 & 971 & 870 & 991 & 1793 & 82.1 & 1200 & 26.4 & 641 & 853 & 858 & 255 & 701 \\
\hline PCB 149 & 228 & 475 & 228 & 219 & 2020 & 2290 & 440 & 17.0 & 2560 & 59.4 & 1520 & 1970 & 2010 & 653 & 1720 \\
\hline PCB 118 & 759 & 1937 & 1363 & 574 & 1780 & 1900 & 858 & 52.1 & 962 & 46.9 & 1120 & 1800 & 1690 & 523 & 1160 \\
\hline PCB 153 & 1651 & 4348 & 2943 & 1426 & 8690 & 10100 & 2064 & 115 & 14200 & 287 & 6510 & 8640 & 8930 & 2810 & 7800 \\
\hline PCB 105 & 9484 & 19324 & 21122 & 6680 & 447 & 486 & 9185 & 551 & 205 & 9.39 & 281 & 457 & 438 & 135 & 256 \\
\hline PCB 138 & 5564 & 11501 & 10194 & 3513 & 4190 & 4920 & 4920 & 292 & 6960 & 105 & 3140 & 4230 & 4410 & 1450 & 3790 \\
\hline PCB 187 & 3977 & 6077 & 8395 & 2372 & 3460 & 4120 & 3526 & 309 & 5570 & 140 & 2600 & 3490 & 3700 & 1440 & 3190 \\
\hline PCB 183 & 1231 & 3008 & 2974 & 725 & 935 & 1110 & 928 & 83.7 & 1700 & 45.3 & 726 & 925 & 991 & 392 & 874 \\
\hline PCB 128 & 608 & 1405 & 813 & 457 & 743 & 863 & 798 & 50.7 & 750 & 22.8 & 541 & 746 & 773 & 234 & 562 \\
\hline PCB 201 & 586 & 1256 & 1172 & 364 & 563 & 653 & 520 & 50.5 & 841 & 28.8 & 431 & 553 & 586 & 212 & 497 \\
\hline РCB 156 & 86.8 & 151 & 76.5 & 67.3 & 231 & 230 & 228 & 18.3 & 51.0 & 9.03 & 117 & 236 & 210 & 84.2 & 70.6 \\
\hline PCB 180 & 4062 & 8451 & 9669 & 2186 & 3050 & 3770 & 2989 & 252 & 5770 & 151 & 2510 & 3100 & 3440 & 1330 & 2950 \\
\hline PCB 170 & 1340 & 2669 & 2952 & 774 & 955 & 1180 & 968 & 81.2 & 1720 & 47.5 & 791 & 978 & 1080 & 400 & 896 \\
\hline РCB 195 & 198 & 393 & 252 & 129 & 221 & 269 & 166 & 40.4 & 248 & 23.2 & 157 & 224 & 244 & 118 & 200 \\
\hline PCB 194 & 709 & 1429 & 1573 & 458 & 535 & 691 & 455 & 92.0 & 912 & 61.8 & 486 & 557 & 641 & 313 & 566 \\
\hline PCB 206 & 369 & 490 & 400 & 202 & 301 & 398 & 254 & 95.6 & 246 & 65.2 & 302 & 317 & 365 & 220 & 327 \\
\hline PCB 209 & 104 & 96.3 & 136 & 72.4 & 69.8 & 94.5 & 55.1 & 63.4 & 57.9 & 39.6 & 62.2 & 71.8 & 86.0 & 97.7 & 85.2 \\
\hline$\Sigma \mathrm{PCBs}$ & 35877 & 73578 & 71092 & 24922 & 35463 & 40715 & 38099 & 2592 & 49412 & 1305 & 26081 & 37523 & 36203 & 12406 & 29335 \\
\hline
\end{tabular}


Table A6: Concentrations (ng/g lipid mass) of Organochlorine pesticides determined in rough-toothed dolphin blubber homogenates. Values for RTDL-001 to -006 are the average of the values determined by the Charleston and Gaithersburg NIST laboratories.

\begin{tabular}{|c|c|c|c|c|c|c|c|c|c|c|c|c|c|c|c|}
\hline \multirow[b]{2}{*}{ Compound } & \multicolumn{6}{|c|}{ Males } & \multicolumn{9}{|c|}{ Females } \\
\hline & $\begin{array}{c}\text { RTDL- } \\
002 \\
\end{array}$ & $\begin{array}{c}\text { RTDL- } \\
004\end{array}$ & $\begin{array}{c}\text { RTDL- } \\
005\end{array}$ & $\begin{array}{c}\text { RTDL- } \\
006\end{array}$ & $\begin{array}{c}\text { RTDL- } \\
012\end{array}$ & $\begin{array}{c}\text { RTDL- } \\
014\end{array}$ & $\begin{array}{c}\text { RTDL- } \\
001\end{array}$ & $\begin{array}{c}\text { RTDL- } \\
003\end{array}$ & $\begin{array}{c}\text { RTDL- } \\
\mathbf{0 0 7}\end{array}$ & $\begin{array}{c}\text { RTDL- } \\
008\end{array}$ & $\begin{array}{c}\text { RTDL- } \\
009\end{array}$ & $\begin{array}{c}\text { RTDL- } \\
010\end{array}$ & $\begin{array}{c}\text { RTDL- } \\
011\end{array}$ & $\begin{array}{c}\text { RTDL- } \\
013\end{array}$ & $\begin{array}{c}\text { RTDL- } \\
015\end{array}$ \\
\hline$\alpha-\mathrm{HCH}$ & 3.96 & 8.45 & 5.13 & 2.61 & 8.01 & 6.28 & 78.4 & $<2$ & 20.7 & 5.29 & 3.56 & 29.2 & 7.41 & 8.02 & $<1$ \\
\hline$\beta-\mathrm{HCH}$ & 10.6 & 36.7 & 14.2 & 13.6 & 15.9 & 11.2 & 168 & $<2$ & 69.4 & $<1$ & 19.7 & 52.5 & 23.2 & 4.86 & 8.64 \\
\hline$\gamma-\mathrm{HCH}$ & $<2$ & $<2$ & $<2$ & $<2$ & $<2$ & $<2$ & 20.8 & 9.21 & $<1$ & $<1$ & $<1$ & 7 & $<1$ & $<1$ & $<1$ \\
\hline$\Sigma \mathrm{HCHs}$ & 14.5 & 45.1 & 19.3 & 16.2 & 23.9 & 17.5 & 267 & 9.21 & 90.1 & 5.29 & 23.3 & 88.2 & 30.6 & 12.9 & 8.64 \\
\hline heptachlor & $<2$ & $<2$ & $<2$ & $<2$ & $<2$ & $<2$ & $<2$ & $<2$ & $<2$ & $<2$ & $<2$ & $<2$ & $<2$ & $<2$ & $<2$ \\
\hline hepta. epoxide & 90.3 & 164 & 80.8 & 52.9 & 77.3 & 96.2 & 460 & $<2$ & 172 & $<1$ & 111 & 214 & 84.3 & 16.7 & 102 \\
\hline trans-chlordane & $<1$ & 10.3 & $<1$ & $<1$ & 8 & $<1$ & 114 & $<1$ & $<1$ & $<1$ & $<1$ & 48.8 & 2.01 & 6.58 & $<1$ \\
\hline cis-chlordane & 78.9 & 223 & 90.7 & 51.9 & 229 & 225 & 1221 & 44.2 & 88.8 & 14.5 & 104.2 & 543 & 196 & 64.7 & 98.7 \\
\hline trans-nonachlor & 2289 & 6172 & 4853 & 1059 & 1440 & 1850 & 7514 & 100 & 5430 & 21.5 & 1380 & 3340 & 1610 & 435 & 1440 \\
\hline cis-nonachlor & 423 & 1132 & 478 & 287 & 586 & 666 & 2840 & 40.5 & 583 & $<1$ & 427 & 1320 & 591 & 175 & 437 \\
\hline oxychlordane & 206 & 498 & 304 & 164 & 233 & 268 & 234 & 10.2 & 503 & 4.31 & 237 & 228 & 242 & 43.4 & 163 \\
\hline Echlordanes & 3087 & 8199 & 5806 & 1615 & 2574 & 3105 & 12384 & 195 & 6777 & 40.3 & 2259 & 5694 & 2726 & 742 & 2240 \\
\hline 2,4'-DDE & 120 & 385 & 257 & 299 & 237 & 242 & 220 & 9.95 & 214 & 5.88 & 157 & 239 & 213 & 84.8 & 116 \\
\hline $4,4^{\prime}-\mathrm{DDE}$ & 13001 & 31809 & 34710 & 7954 & 10200 & 12400 & 16756 & 568 & 26800 & 243 & 8630 & 10500 & 10600 & 2960 & 8610 \\
\hline 2,4'-DDT & 667 & 1040 & 976 & 323 & 549 & 637 & 637 & 29.6 & 762 & $<1$ & 616 & 551 & 602 & $<1$ & 415 \\
\hline 4,4'-DDT & 1481 & 2278 & 1047 & 880 & 1930 & 2400 & 10186 & 68.9 & 1310 & 43.1 & 1750 & 4240 & 2010 & 532 & 1290 \\
\hline $2,4^{\prime}-\mathrm{DDD}$ & 62 & 129 & 137 & 65.0 & 61.1 & 80.3 & 315 & $<2$ & 65.8 & $<1$ & 77 & 154 & 71.6 & 18.0 & 66.9 \\
\hline 4,4'-DDD & 778 & 1675 & 742 & 741 & 1150 & 1390 & 6784 & 101 & 882 & 6.02 & 1050 & 3080 & 1200 & 362 & 847 \\
\hline$\Sigma$ DDTs & 16109 & 37317 & 37868 & 10262 & 14127 & 17149 & 34898 & 778 & 30033 & 298 & 12280 & 18764 & 14697 & 3956 & 11345 \\
\hline mirex & 550 & 1145 & 1134 & 348 & 485 & 596 & 421 & 46.1 & 912 & 33.4 & 414 & 496 & 527 & 165 & 369 \\
\hline & 20.8 & 79.5 & 28.3 & 92.0 & 72.7 & 77.3 & 68.0 & $<2$ & 31.7 & 6.04 & 62.6 & 70.9 & 70.2 & 19.6 & 56.4 \\
\hline dieldrin & 201 & 487 & 186 & 189 & 361 & 412 & 1835 & 46.9 & 326 & 18.4 & 346 & 907 & 367 & 81.0 & 280 \\
\hline
\end{tabular}



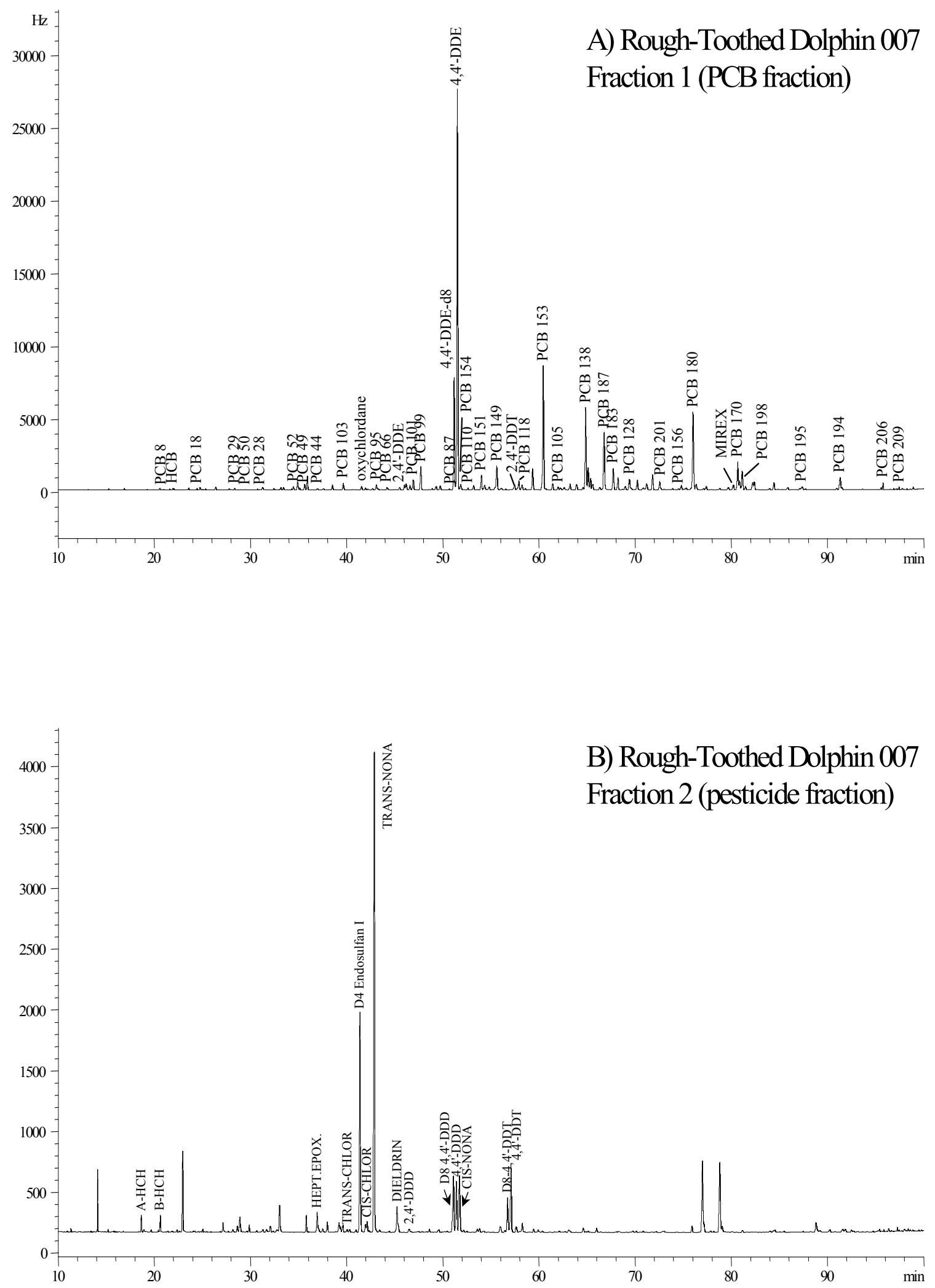

Figure A1: Chromatograms from the analysis of the PCB (A) and pesticide fractions (B) of RTDL-007 by the NIST Charleston Laboratory. 


\section{APPENDIX B}

\section{Elements: Analytical Data}


Table B1: Rough-toothed dolphin liver (L) and kidney (K) specimen identification codes, ratios of dry to wet mass, and \% total extractable organic content.

\begin{tabular}{ccccccc}
\hline $\begin{array}{c}\text { NMMTB Animal } \\
\text { Identification }\end{array}$ & $\begin{array}{c}\text { NIST Liver } \\
\text { Specimen } \\
\text { Identification Code }\end{array}$ & $\begin{array}{c}\text { Dry to Wet } \\
\text { Mass Ratio }\end{array}$ & $\begin{array}{c}\text { Total } \\
\text { Extractable } \\
\text { Organics }\end{array}$ & $\begin{array}{c}\text { NIST Kidney } \\
\text { Specimen } \\
\text { Identification Code }\end{array}$ & $\begin{array}{c}\text { Dry to Wet } \\
\text { Mass Ratio }\end{array}$ & $\begin{array}{c}\text { Total } \\
\text { Extractable } \\
\text { Organics }\end{array}$ \\
\hline RTDL-001 & NM8L678.B003 & 0.2378 & 3.29 & NM8K679 & 0.2204 & 5.25 \\
RTDL-002 & NM8L681.B003 & 0.2392 & 4.02 & NM8K682 & 0.2187 & 6.72 \\
RTDL-003 & NM8L684.B003 & 0.2676 & 6.63 & NM8K685 & 0.2483 & 15.8 \\
RTDL-004 & NM8L687.B003 & 0.2566 & 4.02 & NM8K688 & 0.2106 & 5.92 \\
RTDL-005 & NM8L690.B003 & 0.2663 & 6.21 & NM8K691 & 0.3657 & 20.5 \\
RTDL-006 & NM8L693.B003 & 0.2566 & 5.37 & NM8K694 & 0.2250 & 6.13 \\
RTDL-007 & NM8L696.B003 & 0.2694 & 3.84 & NM8K697 & 0.3615 & 32.4 \\
RTDL-008 & NM8L699.B003 & 0.2661 & 6.97 & NM8K700 & 0.3322 & 29.8 \\
RTDL-009 & NM8L702.B003 & 0.2407 & 5.17 & NM8K703 & 0.2360 & 9.6 \\
RTDL-010 & NM8L705.B003 & 0.2546 & 5.40 & NM8K706 & 0.2704 & 12.2 \\
RTDL-011 & NM8L708.B003 & 0.2692 & 4.87 & NM8K709 & 0.2410 & 9.3 \\
RTDL-012 & NM8L711.B003 & 0.2619 & 4.15 & NM8K712 & 0.2205 & 5.9 \\
RTDL-013 & NM8L714.B003 & 0.2585 & 3.86 & NM8K715 & 0.5530 & 45.2 \\
RTDL-014 & NM8L717.B003 & 0.2717 & 4.02 & NM8K718 & 0.2196 & 7.19 \\
RTDL-015 & NM8L720.B003 & 0.2519 & 5.42 & NM8K721 & 0.1977 & 6.27 \\
\hline
\end{tabular}


Table B2: INAA Detection limits for elements in tissue specimens.

\begin{tabular}{cc}
\hline Element & INAA Detection Limit $(\mathbf{m g} / \mathbf{k g})$ \\
\hline Sc & 0.0003 \\
$\mathbf{V}$ & 0.02 \\
Sr & 1 \\
Mo & 0.5 \\
$\mathbf{C d}$ & 0.4 \\
Sn & 1 \\
Sb & 3 \\
I & 3 \\
Ba & 5 \\
La & 0.01 \\
Ce & 0.02 \\
Sm & 0.005 \\
Eu & 0.0005 \\
Tb & 0.001 \\
Hf & 0.001 \\
Ta & 0.0004 \\
Au & 0.004 \\
Th & 0.002 \\
U & 0.1 \\
\hline
\end{tabular}


Table B3: Results of INAA and ICP-MS analyses of rough-toothed dolphin kidney and liver tissues. Values for mass fraction, uncertainties associated with counting statistics $\left(\mathrm{u}_{\mathrm{cs}}\right)$, and expanded uncertainties $(\mathrm{U} ; \mathrm{k}=2)$ are expressed as $\mathrm{mg} / \mathrm{kg}$ of wet mass.

\begin{tabular}{|c|c|c|c|c|c|c|c|c|c|c|c|c|c|c|c|c|}
\hline Animal ID & NBSB Tissue ID & $\begin{array}{c}\mathrm{Na} \\
(\mathrm{mg} / \mathrm{kg}) \\
\end{array}$ & $\mathbf{u}_{\mathrm{cs}}$ & $\mathbf{U}$ & $\begin{array}{l}\text { Mg } \\
(\mathrm{mg} / \mathrm{kg})\end{array}$ & $\mathbf{u}_{\mathrm{cs}}$ & $\mathbf{U}$ & Cl & $\mathbf{u}_{\mathrm{cs}}$ & $\mathbf{U}$ & $\mathbf{K}$ & $\mathbf{u}_{\mathrm{cs}}$ & $\mathbf{U}$ & $\mathbf{C a}$ & $\mathbf{u}_{\mathrm{cs}}$ & $\mathbf{U}$ \\
\hline \multirow[t]{4}{*}{ RTDL-001 } & NM8K679.B003.A & 1970 & 18 & 46 & 75 & 15 & 30 & 2527 & 21 & 55 & 2964 & 37 & 85 & 50 & 6 & 12 \\
\hline & NM8K679.B003.B & 1951 & 18 & 45 & 120 & 10 & 20 & 2695 & 23 & 60 & 2817 & 36 & 82 & 64 & 8 & 16 \\
\hline & NM8L678.B003.A & 1426 & 6 & 37 & 174 & 6 & 13 & 1883 & 13 & 53 & 2854 & 33 & 96 & 57 & 5 & 10 \\
\hline & NM8L678.B003.B & 1420 & 6 & 37 & 174 & 7 & 15 & 1868 & 14 & 54 & 2937 & 32 & 96 & 58 & 7 & 14 \\
\hline \multirow[t]{4}{*}{ RTDL-002 } & NM8K682.B003.A & 1880 & 17 & 43 & 137 & 10 & 20 & 2236 & 19 & 49 & 2184 & 29 & 66 & 110 & 8 & 16 \\
\hline & NM8K682.B003.B & 1853 & 17 & 43 & 130 & 10 & 20 & 2202 & 19 & 49 & 2174 & 37 & 80 & 131 & 8 & 16 \\
\hline & NM8L681.B003.A & 1714 & 7 & 44 & 153 & 5 & 11 & 1967 & 13 & 55 & 2362 & 32 & 86 & 40 & 3 & 6 \\
\hline & NM8L681.B003.B & 1695 & 7 & 44 & 181 & 8 & 17 & 1931 & 15 & 56 & 2303 & 29 & 81 & 48 & 4 & 8 \\
\hline \multirow[t]{4}{*}{ RTDL-003 } & NM8K685.B003.A & 1985 & 18 & 46 & 106 & 10 & 20 & 1504 & 13 & 34 & 1594 & 29 & 62 & 360 & 17 & 34 \\
\hline & NM8K685.B003.B & 1903 & 18 & 45 & 156 & 15 & 30 & 2335 & 19 & 50 & 1532 & 29 & 62 & 320 & 15 & 30 \\
\hline & NM8L684.B003.A & 1465 & 6 & 38 & 133 & 5 & 11 & 1903 & 13 & 53 & 2525 & 34 & 92 & 30 & 4 & 8 \\
\hline & NM8L684.B003.B & 1450 & 6 & 38 & 141 & 6 & 12 & 1908 & 12 & 53 & 25001 & 29 & 84 & 456 & 10 & 23 \\
\hline \multirow[t]{4}{*}{ RTDL-004 } & NM8K688.B003.A & 1860 & 17 & 43 & 132 & 9 & 18 & 2341 & 20 & 52 & 2640 & 42 & 92 & 150 & 9 & 18 \\
\hline & NM8K688.B003.B & 1863 & 17 & 43 & 120 & 9 & 18 & 2284 & 19 & 50 & 2482 & 30 & 69 & 136 & 9 & 18 \\
\hline & NM8L687.B003.A & 1393 & 6 & 36 & 158 & 5 & 11 & 1817 & 11 & 50 & 2882 & 34 & 98 & 32 & 3 & 6 \\
\hline & NM8L687.B003.B & 1368 & 6 & 36 & 158 & 6 & 13 & 1780 & 11 & 49 & 2878 & 28 & 90 & 30 & 3 & 6 \\
\hline \multirow[t]{4}{*}{ RTDL-005 } & NM8K691.B003.A & 2358 & 22 & 55 & 85 & 7 & 14 & 1569 & 15 & 37 & 1629 & 36 & 76 & 935 & 22 & 46 \\
\hline & NM8K691.B003.B & 2235 & 21 & 53 & 142 & 12 & 24 & 2754 & 25 & 63 & 1591 & 37 & 77 & 1459 & 37 & 77 \\
\hline & NM8L690.B003.A & 1477 & 6 & 38 & 149 & 5 & 11 & 1754 & 11 & 48 & 2673 & 29 & 87 & 23 & 4 & 8 \\
\hline & NM8L690.B003.B & 1465 & 6 & 38 & 137 & 11 & 22 & 1736 & 11 & 48 & 2638 & 28 & 86 & 23 & 3 & 6 \\
\hline \multirow[t]{4}{*}{ RTDL-006 } & NM8K694.B003.A & 1886 & 17 & 43 & 116 & 8 & 16 & 2334 & 20 & 52 & 2680 & 39 & 87 & 173 & 9 & 18 \\
\hline & NM8K694.B003.B & 1868 & 17 & 43 & 145 & 9 & 18 & 2278 & 19 & 50 & 2551 & 41 & 89 & 153 & 9 & 18 \\
\hline & NM8L693.B003.A & 1540 & 7 & 40 & 152 & 4 & 9 & 1883 & 11 & 51 & 2732 & 33 & 94 & 49 & 4 & 8 \\
\hline & NM8L693.B003.B & 1515 & 8 & 40 & 147 & 6 & 13 & 1831 & 11 & 50 & 2608 & 34 & 93 & 56 & 4 & 8 \\
\hline \multirow[t]{4}{*}{ RTDL-007 } & NM8K697.B003.A & 1931 & 18 & 45 & 88 & 7 & 14 & 1094 & 12 & 29 & 1917 & 17 & 43 & 214 & 10 & 20 \\
\hline & NM8K697.B003.B & 1938 & 18 & 45 & 101 & 11 & 22 & 2177 & 19 & 49 & 2224 & 38 & 82 & 421 & 20 & 40 \\
\hline & NM8L696.B003.A & 1341 & 6 & 35 & 165 & 5 & 11 & 1824 & 11 & 50 & 3031 & 31 & 97 & 63 & 5 & 10 \\
\hline & NM8L696.B003.B & 1324 & 6 & 35 & 176 & 7 & 15 & 1809 & 11 & 49 & 2996 & 31 & 96 & 42 & 4 & 8 \\
\hline \multirow[t]{4}{*}{ RTDL-008 } & NM8K700.B003.A & 2213 & 12 & 39 & 225 & 15 & 30 & 2396 & 13 & 43 & 1876 & 34 & 73 & 367 & 15 & 30 \\
\hline & NM8K700.B003.B & 1844 & 17 & 43 & 185 & 16 & 32 & 2049 & 17 & 45 & 1938 & 37 & 79 & 264 & 13 & 26 \\
\hline & NM8L699.B003.A & 1645 & 7 & 43 & 169 & 5 & 11 & 1857 & 12 & 51 & 2521 & 32 & 89 & 33 & 4 & 8 \\
\hline & NM8L699.B003.B & 1613 & 7 & 42 & 169 & 7 & 15 & 1842 & 12 & 51 & 2463 & 35 & 92 & 46 & 5 & 10 \\
\hline
\end{tabular}

*Results are from INAA unless otherwise indicated by the NBSB Tissue ID code. 
Table B3 (Continued): Results of INAA and ICP-MS analyses of rough-toothed dolphin kidney and liver tissues. Values for mass fraction, uncertainties associated with counting statistics $\left(\mathrm{u}_{\mathrm{cs}}\right)$, and expanded uncertainties $(\mathrm{U} ; \mathrm{k}=2)$ are expressed as $\mathrm{mg} / \mathrm{kg}$ of wet mass.

\begin{tabular}{|c|c|c|c|c|c|c|c|c|c|c|c|c|c|c|c|c|}
\hline Animal ID & NBSB Tissue ID & $\begin{array}{c}\mathrm{Na} \\
\mathrm{mg} / \mathrm{kg}\end{array}$ & $\mathbf{u}_{\mathrm{cs}}$ & $\mathbf{U}$ & $\begin{array}{l}\mathrm{Mg} \\
\mathrm{mg} / \mathrm{kg} \\
\end{array}$ & $\mathbf{u}_{\mathrm{cs}}$ & $\mathbf{U}$ & \begin{tabular}{|l|}
$\mathrm{Cl}$ \\
$\mathrm{mg} / \mathrm{kg}$ \\
\end{tabular} & $\mathbf{u}_{\mathrm{cs}}$ & $\mathbf{U}$ & \begin{tabular}{|c|}
$\mathrm{K}$ \\
$\mathrm{mg} / \mathrm{kg}$ \\
\end{tabular} & $\mathbf{u}_{\mathrm{cs}}$ & $\mathbf{U}$ & \begin{tabular}{|l|}
$\mathrm{Ca}$ \\
$\mathrm{mg} / \mathrm{kg}$ \\
\end{tabular} & $\mathbf{u}_{\mathbf{c s}}$ & $\mathbf{U}$ \\
\hline \multirow[t]{7}{*}{ RTDL-009 } & NM8K703.B003.A & 2244 & 21 & 53 & 106 & 11 & 22 & 2947 & 25 & 65 & 1921 & 42 & 88 & 221 & 11 & 22 \\
\hline & NM8K703.B003.B & 2215 & 21 & 52 & 123 & 24 & 48 & 2916 & 24 & 63 & 1891 & 42 & 88 & 216 & 12 & 24 \\
\hline & NM8L702.B003.A & 1591 & 7 & 41 & 126 & 10 & 20 & 1985 & 12 & 54 & 2352 & 28 & 80 & 39 & 4 & 8 \\
\hline & NM8L702.B003.B & 1563 & 7 & 41 & 119 & 6 & 12 & 1927 & 12 & 53 & 2361 & 28 & 81 & 38 & 3 & 6 \\
\hline & NM8K706.B003.B & 1706 & 3 & 25 & 63 & 17 & 34 & 1993 & 17 & 44 & 1982 & 142 & 285 & 145 & 9 & 18 \\
\hline & NM8L705.B003.A & 1553 & 7 & 41 & 146 & 5 & 11 & 1913 & 12 & 53 & 2396 & 34 & 90 & 26 & 4 & 8 \\
\hline & NM8L705.B003.B & 1540 & 7 & 41 & 149 & 11 & 22 & 1895 & 12 & 52 & 2464 & 32 & 88 & 41 & 4 & 8 \\
\hline \multirow[t]{4}{*}{ RTDL-011 } & NM8K709.B003.A & 1820 & 17 & 43 & 112 & 16 & 32 & 2335 & 21 & 53 & 2480 & 37 & 82 & 362 & 15 & 30 \\
\hline & NM8K709.B003.B & 1769 & 17 & 42 & 136 & 19 & 38 & 2124 & 18 & 47 & 2371 & 35 & 78 & 396 & 14 & 29 \\
\hline & NM8L708.B003.A & 1446 & 7 & 38 & 176 & 12 & 24 & 1952 & 15 & 56 & 3048 & 32 & 98 & 60 & 4 & 8 \\
\hline & NM8L708.B003.B & 1435 & 6 & 37 & 182 & 8 & 17 & 1972 & 12 & 54 & 2943 & 36 & 102 & 61 & 4 & 8 \\
\hline \multirow[t]{4}{*}{ RTDL-012 } & NM8K712.B003.A & 1977 & 18 & 46 & 148 & 10 & 20 & 2670 & 22 & 58 & 3135 & 37 & 86 & 68 & 8 & 16 \\
\hline & NM8K712.B003.B & 1933 & 18 & 45 & 113 & 17 & 34 & 2481 & 21 & 55 & 2892 & 35 & 81 & 58 & 7 & 14 \\
\hline & NM8L711.B003.A & 1048 & 5 & 28 & 182 & 6 & 13 & 1353 & 9 & 38 & 3566 & 32 & 108 & 47 & 5 & 10 \\
\hline & NM8L711.B003.B & 1039 & 5 & 27 & 191 & 6 & 13 & 1332 & 9 & 87 & 3564 & 45 & 125 & 34 & 5 & 10 \\
\hline \multirow[t]{4}{*}{ RTDL-013 } & NM8K715.B003.A & 822 & 10 & 23 & 45 & 4 & 8 & 1006 & 8 & 21 & 803 & 63 & 127 & $<13$ & -- & -- \\
\hline & NM8K715.B003.B & 1220 & 14 & 33 & 49 & 9 & 18 & 1507 & 12 & 32 & 1060 & 68 & 137 & $<16$ & -- & -- \\
\hline & NM8L714.B003.A & 1518 & 7 & 40 & 161 & 5 & 11 & 1847 & 11 & 50 & 2566 & 30 & 87 & 47 & 4 & 8 \\
\hline & NM8L714.B003.B & 1505 & 7 & 39 & 153 & 7 & 14 & 1848 & 11 & 50 & 2635 & 39 & 101 & 49 & 5 & 10 \\
\hline \multirow{4}{*}{ RTDL-014 } & NM8K718.B003.A & 1793 & 17 & 42 & 106 & 16 & 32 & 2466 & 21 & 55 & 2566 & 40 & 88 & 404 & 14 & 29 \\
\hline & NM8K718.B003.B & 1841 & 17 & 43 & 84 & 17 & 34 & 2474 & 20 & 53 & 2721 & 34 & 78 & 367 & 12 & 25 \\
\hline & NM8L717.B003.A & 1365 & 6 & 36 & 167 & 7 & 15 & 1768 & 11 & 49 & 3255 & 37 & 109 & 53 & 5 & 10 \\
\hline & NM8L717.B003.B & 1367 & 6 & 36 & 184 & 6 & 13 & 1808 & 11 & 49 & 3257 & 41 & 114 & 48 & 4 & 8 \\
\hline \multirow[t]{4}{*}{ RTDL-015 } & NM8K721.B003.A & 1982 & 19 & 47 & 135 & 21 & 42 & 2276 & 19 & 50 & 2281 & 30 & 68 & 166 & 9 & 18 \\
\hline & NM8K721.B003.B & 1953 & 18 & 45 & 129 & 18 & 36 & 2117 & 18 & 47 & 2194 & 32 & 71 & 165 & 9 & 18 \\
\hline & NM8L720.B003.A & 1658 & 7 & 43 & 118 & 13 & 26 & 2016 & 12 & 55 & 2813 & 34 & 97 & 68 & 6 & 12 \\
\hline & NM8L720.B003.B & 1659 & 7 & 43 & 123 & 11 & 22 & 2008 & 12 & 55 & 2873 & 38 & 104 & 52 & 4 & 8 \\
\hline
\end{tabular}

*Results are from INAA unless otherwise indicated by the NBSB Tissue ID code. 
Table B3 (Continued): Results of INAA and ICP-MS analyses of rough-toothed dolphin kidney and liver tissues. Values for mass fraction, uncertainties associated with counting statistics $\left(\mathrm{u}_{\mathrm{cs}}\right)$, and expanded uncertainties $(\mathrm{U} ; \mathrm{k}=2)$ are expressed as $\mathrm{mg} / \mathrm{kg}$ of wet mass.

\begin{tabular}{|c|c|c|c|c|c|c|c|c|c|c|c|c|c|}
\hline Animal ID & NBSB Tissue ID & $\begin{array}{l}\mathrm{Cu} \\
\mathrm{mg} / \mathrm{kg}\end{array}$ & $\mathbf{u}_{\mathrm{cs}}$ & $\mathbf{U}$ & $\begin{array}{l}\text { Mn } \\
\mathrm{mg} / \mathrm{kg}\end{array}$ & $\mathbf{u}_{\mathrm{cs}}$ & $\mathbf{U}$ & $\begin{array}{l}\mathrm{Br} \\
\mathrm{mg} / \mathrm{kg}\end{array}$ & $\mathbf{u}_{\mathrm{cs}}$ & $\mathbf{U}$ & $\begin{array}{l}\mathrm{Fe} \\
\mathrm{mg} / \mathrm{kg}\end{array}$ & $\mathbf{u}_{\mathrm{cs}}$ & $\mathbf{U}$ \\
\hline \multirow[t]{6}{*}{ RTDL-001 } & NM8K679.B003.A & $<3$ & -- & -- & 0.57 & 0.02 & 0.04 & 19.5 & 1.4 & 2.8 & 77 & 1 & 3 \\
\hline & NM8K679.B003.B & $<3$ & - & - - & 0.61 & 0.03 & 0.06 & 23.5 & 1.6 & 3.2 & 77 & 1 & 3 \\
\hline & NM8K679.ICPMS & 3.4 & - & 0.4 & 0.72 & - & 0.09 & - & - & - & - & - & - \\
\hline & NM8L678B003.A & $<3$ & - - & - - & 3.09 & 0.02 & 0.08 & 22.8 & 1.7 & 3.4 & 446 & 5 & 15 \\
\hline & NM8L678.B003.B & $<3$ & - - & - - & 3.05 & 0.02 & 0.09 & 20.2 & 1.5 & 3.0 & 459 & 5 & 15 \\
\hline & NM8L678.ICPMS & 5.5 & - - & 0.6 & 3.9 & -- & 0.5 & -- & - & - & - - & - & - \\
\hline \multirow[t]{6}{*}{ RTDL-002 } & NM8K682.B003.A & $<3$ & - - & - & 0.55 & 0.03 & 0.05 & 21.4 & 1.6 & 3.2 & 70 & 1 & 3 \\
\hline & NM8K682.B003.B & $<3$ & - & - & 0.55 & 0.02 & 0.03 & 18.4 & 1.7 & 3.4 & 71 & 1 & 3 \\
\hline & NM8K682.ICPMS & 2.6 & 0.3 & 0.3 & 0.74 & - & 0.17 & - - & - & - & - & - & - \\
\hline & NM8L681.B003.A & 5.4 & 0.4 & 0.8 & 2.82 & 0.02 & 0.08 & 18.4 & 1.3 & 2.6 & 217 & 2 & 7 \\
\hline & NM8L681.B003.B & 5.6 & 0.5 & 1.1 & 2.80 & 0.02 & 0.08 & 22.2 & 1.5 & 3.0 & 214 & 2 & 7 \\
\hline & NM8L681.ICPMS & 8.2 & - - & 5.3 & 4.3 & - - & 3.1 & - - & - - & - & - & - - & - - \\
\hline \multirow[t]{6}{*}{ RTDL-003 } & NM8K685.B003.A & $<3$ & - - & - - & 0.39 & 0.02 & 0.04 & 19.3 & 1.6 & 3.2 & 66 & 1 & 3 \\
\hline & NM8K685.B003.B & $<3$ & - - & - - & 0.29 & 0.02 & 0.03 & 19.9 & 1.6 & 3.2 & 60 & 1 & 3 \\
\hline & NM8K685.ICPMS & 2.1 & 0.3 & 0.3 & 0.48 & -- & 0.09 & - & - & - & - & - & - \\
\hline & NM8L684.B003.A & 6.5 & 0.3 & 0.6 & 3.73 & 0.02 & 0.10 & 21.4 & 1.7 & 3.4 & 243 & 3 & 8 \\
\hline & NM8L684.B003.B & 5.2 & 0.4 & 0.8 & 3.56 & 0.03 & 0.11 & 21.3 & 1.4 & 2.8 & 245 & 3 & 8 \\
\hline & NM8L684.ICPMS & 8.5 & - - & 1.0 & 4.9 & - - & 0.6 & - - & - & - & - - & - - & - - \\
\hline \multirow[t]{6}{*}{ RTDL-004 } & NM8K688.B003.A & $<4$ & - - & - & 0.58 & 0.05 & 0.11 & 17.9 & 1.7 & 3.4 & 48 & 1 & 2 \\
\hline & NM8K688.B003.B & $<4$ & - - & - - & 0.60 & 0.06 & 0.12 & 23.6 & 1.9 & 3.8 & 48 & 1 & 2 \\
\hline & NM8K688.ICPMS & 3.3 & 0.4 & 0.4 & 0.79 & - & 0.13 & - & - & - & - & - & - - \\
\hline & NM8L687.B003.A & 4.8 & 0.5 & 0.9 & 4.26 & 0.02 & 0.11 & 19.1 & 1.6 & 3.2 & 224 & 3 & 8 \\
\hline & NM8L687.B003.B & 4.3 & 0.3 & 0.5 & 4.21 & 0.03 & 0.12 & 20.5 & 1.3 & 2.6 & 229 & 3 & 8 \\
\hline & NM8L687.ICPMS & 5.8 & - - & 2.1 & 5.6 & - & 2.5 & - & - - & - & - & - - & - - \\
\hline \multirow[t]{6}{*}{ RTDL-005 } & NM8K691.B003.A & $<4$ & - - & - & 0.45 & 0.03 & 0.05 & 20.6 & 2.1 & 4.2 & 47 & 1 & 2 \\
\hline & NM8K691.B003.B & $<4$ & - & - & 0.48 & 0.06 & 0.06 & 19.1 & 1.4 & 2.8 & 73 & 1 & 2 \\
\hline & NM8K691.ICPMS & 1.7 & 0.2 & 0.2 & 0.45 & - & 0.06 & - & -- & -- & - & - & - \\
\hline & NM8L690.B003.A & 7.5 & 0.4 & 0.8 & 3.30 & 0.02 & 0.09 & 21.6 & 1.5 & 3.0 & 255 & 3 & 9 \\
\hline & NM8L690.B003.B & 7.1 & 0.3 & 0.7 & 3.34 & 0.03 & 0.10 & 21.9 & 1.2 & 2.5 & 257 & 3 & 9 \\
\hline & NM8L690.ICPMS & 8.4 & - - & 1.0 & 4.2 & -- & 0.5 & - & -- & - & - & - - & - - \\
\hline \multirow[t]{6}{*}{ RTDL-006 } & NM8K694.B003.A & $<4$ & - - & - & 0.75 & 0.07 & 0.14 & 19.0 & 1.6 & 3.2 & 49 & 1 & 2 \\
\hline & NM8K694.B003.B & $<4$ & - & - - & 0.70 & 0.02 & 0.04 & 19.6 & 1.8 & 3.6 & 47 & 1 & 2 \\
\hline & NM8K694.ICPMS & 3.5 & 0.5 & 0.5 & 0.90 & -- & 0.15 & -- & 1.0 & - & - & - & - \\
\hline & NM8L693.B003.A & 6.1 & 0.3 & 0.7 & 4.26 & 0.02 & 0.11 & 24.3 & 1.8 & 3.6 & 170 & 2 & 6 \\
\hline & NM8L693.B003.B & 6.1 & 0.3 & 0.6 & 4.14 & 0.04 & 0.13 & 24.7 & 1.4 & 2.9 & 167 & 2 & 6 \\
\hline & NM8L693.ICPMS & 8.1 & - - & 1.0 & 5.3 & - & 0.6 & - & - & - & - & - - & - \\
\hline
\end{tabular}

*Results are from INAA unless otherwise indicated by the NBSB Tissue ID code. 
Table B3 (Continued): Results of INAA and ICP-MS analyses of rough-toothed dolphin kidney tissues. Values for mass fraction, uncertainties associated with counting statistics $\left(\mathrm{u}_{\mathrm{cs}}\right)$, and expanded uncertainties $(\mathrm{U} ; \mathrm{k}=2)$ are expressed as $\mathrm{mg} / \mathrm{kg}$ of wet mass.

\begin{tabular}{|c|c|c|c|c|c|c|c|c|c|c|c|c|c|}
\hline Animal ID & NBSB Tissue ID & $\begin{array}{l}\mathrm{Cu} \\
\mathrm{mg} / \mathrm{kg}\end{array}$ & $\mathbf{u}_{\mathrm{cs}}$ & $\mathbf{U}$ & $\begin{array}{l}\mathrm{Mn} \\
\mathrm{mg} / \mathrm{kg}\end{array}$ & $\mathbf{u}_{\mathrm{cs}}$ & $\mathbf{U}$ & $\begin{array}{l}\mathrm{Br} \\
\mathrm{mg} / \mathrm{kg}\end{array}$ & $\mathbf{u}_{\mathrm{cs}}$ & $\mathbf{U}$ & $\begin{array}{l}\mathrm{Fe} \\
\mathrm{mg} / \mathrm{kg}\end{array}$ & $\mathbf{u}_{\mathrm{cs}}$ & $\mathbf{U}$ \\
\hline \multirow{6}{*}{ RTDL-007 } & NM8K697.B003.A & $<5$ & -- & -- & 0.55 & 0.03 & 0.06 & 19.5 & 1.6 & 3.2 & 65 & 1 & 3 \\
\hline & NM8K697.B003.B & $<5$ & - & - & 0.43 & 0.02 & 0.04 & 19.5 & 1.7 & 3.4 & 64 & 1 & 3 \\
\hline & NM8K697.ICPMS & 2.2 & - & 0.6 & 0.53 & -- & 0.18 & -- & - & - & - & - & - \\
\hline & NM8L696.B003.A & 6.3 & 0.4 & 0.9 & 3.66 & 0.03 & 0.11 & 19.5 & 1.5 & 3.0 & 262 & 3 & 9 \\
\hline & NM8L696.B003.B & 6.4 & 0.4 & 0.8 & 3.55 & 0.03 & 0.11 & 19.4 & 1.4 & 2.8 & 272 & 3 & 9 \\
\hline & NM8L696.ICPMS & 7.8 & - & 3.3 & 5.6 & - - & 4.0 & - & - - & - & - & - & - - \\
\hline \multirow[t]{6}{*}{ RTDL-008 } & NM8K700.B003.A & $<5$ & - & - & 0.54 & 0.03 & 0.06 & 20.2 & 1.6 & 3.2 & 40 & 1 & 2 \\
\hline & NM8K700.B003.B & $<5$ & - & - & 0.47 & 0.02 & 0.05 & 19.0 & 1.8 & 3.6 & 44 & 1 & 2 \\
\hline & NM8K700.ICPMS & 2.2 & -- & 0.6 & 0.59 & -- & 0.22 & -- & -- & -- & - & - & - \\
\hline & NM8L699.B003.A & 6.2 & 0.3 & 0.6 & 2.90 & 0.03 & 0.09 & 21.8 & 1.6 & 3.2 & 112 & 1 & 3 \\
\hline & NM8L699.B003.B & 5.7 & 0.3 & 0.6 & 2.76 & 0.03 & 0.09 & 22.1 & 1.5 & 3.0 & 111 & 1 & 3 \\
\hline & NM8L699.ICPMS & 8.0 & - & 5.7 & 4.4 & - - & 4.1 & - - & - - & - - & - - & - - & - - \\
\hline \multirow[t]{6}{*}{ RTDL-009 } & NM8K703.B003.A & $<3$ & - & - & 0.43 & 0.06 & 0.12 & 22.9 & 1.5 & 3.0 & 42 & 1 & 2 \\
\hline & NM8K703.B003.B & $<3$ & - & - & 0.41 & 0.02 & 0.03 & 20.3 & 2.0 & 4.0 & 41 & 1 & 2 \\
\hline & NM8K703.ICPMS & 3.3 & -- & 3.4 & 0.58 & -- & 0.09 & -- & -- & -- & - & - & - \\
\hline & NM8L702.B003.A & 5.5 & 0.5 & 0.9 & 3.35 & 0.02 & 0.10 & 17.9 & 1.1 & 2.2 & 180 & 2 & 6 \\
\hline & NM8L702.B003.B & 4.7 & 0.4 & 0.9 & 3.24 & 0.03 & 0.03 & 17.6 & 1.4 & 2.8 & 177 & 2 & 6 \\
\hline & NM8L702.ICPMS & 9 & - - & 2 & 5.1 & -- & 1.6 & -- & - & - & -- & - & - \\
\hline \multirow[t]{6}{*}{ RTDL-010 } & NM8K706.B003.A & $<3$ & - & - & 0.73 & 0.03 & 0.07 & 21.8 & 1.6 & 3.2 & 449 & 1 & 2 \\
\hline & NM8K706.B003.B & $<3$ & - & - & 0.62 & 0.02 & 0.05 & 17.0 & 1.5 & 3.0 & 47 & 1 & 2 \\
\hline & NM8K706.ICPMS & 2.5 & - & 0.3 & 0.72 & - & 0.12 & -- & - & - & - & - & - \\
\hline & NM8L705.B003.A & 5.9 & 0.4 & 0.8 & 4.57 & 0.02 & 0.12 & 18.4 & 1.6 & 3.2 & 189 & 2 & 6 \\
\hline & NM8L705.B003.B & 5.9 & 0.3 & 0.7 & 4.53 & 0.02 & 0.13 & 17.1 & 1.4 & 2.8 & 190 & 2 & 6 \\
\hline & NM8L705.ICPMS & 8.8 & - - & 1.2 & 6.0 & - & 1.0 & - & - & - & - & - & - \\
\hline \multirow{6}{*}{ RTDL-011 } & NM8K709.B003.A & $<3$ & - - & - - & 0.44 & 0.02 & 0.05 & 17.7 & 1.6 & 3.2 & 52 & 1 & 2 \\
\hline & NM8K709.B003.B & $<3$ & - & - & 0.43 & 0.02 & 0.04 & 15.6 & 1.3 & 2.6 & 49 & 1 & 2 \\
\hline & NM8K709.ICPMS & 2.6 & - & 0.9 & 0.65 & - & 0.08 & - & - & - & - & - & - \\
\hline & NM8L708.B003.A & 4.6 & 0.3 & 0.6 & 3.88 & 0.02 & 0.11 & 20.7 & 1.5 & 3.0 & 202 & 2 & 6 \\
\hline & NM8L708.B003.B & 4.3 & 0.3 & 0.7 & 3.78 & 0.08 & 0.18 & 19.2 & 1.7 & 3.4 & 201 & 2 & 6 \\
\hline & NM8L708.ICPMS & 7.6 & - & 8.7 & 7.0 & -- & 10.0 & - & - & - & -- & - & - \\
\hline \multirow[t]{6}{*}{ RTDL-012 } & NM8K712.B003.A & $<3$ & - & - & 0.71 & 0.03 & 0.06 & 23.3 & 1.5 & 3.0 & 43 & 1 & 2 \\
\hline & NM8K712.B003.B & $<3$ & - & - & 0.62 & 0.02 & 0.04 & 27.9 & 1.8 & 3.6 & 42 & 1 & 2 \\
\hline & NM8K712.ICPMS & 3.2 & - - & 0.4 & 0.90 & - - & 0.22 & - & - - & - & - & - & - \\
\hline & NM8L711.B003.A & 5.1 & 0.4 & 0.9 & 4.44 & 0.02 & 0.12 & 14.4 & 1.0 & 2.0 & 619 & 7 & 21 \\
\hline & NM8L711.B003.B & 4.9 & 0.4 & 0.8 & 4.42 & 0.09 & 0.20 & 14.9 & 1.1 & 2.2 & 610 & 7 & 20 \\
\hline & NM8L711.ICPMS & 5.5 & - - & 0.6 & 5.7 & -- & 0.7 & - & - - & - & - & - & - \\
\hline
\end{tabular}

*Results are from INAA unless otherwise indicated by the NBSB Tissue ID code. 
Table B3 (Continued): Results of INAA and ICP-MS analyses of rough-toothed dolphin kidney tissues. Values for mass fraction, uncertainties associated with counting statistics $\left(\mathrm{u}_{\mathrm{cs}}\right)$, and expanded uncertainties $(\mathrm{U} ; \mathrm{k}=2)$ are expressed as $\mathrm{mg} / \mathrm{kg}$ of wet mass.

\begin{tabular}{|c|c|c|c|c|c|c|c|c|c|c|c|c|c|}
\hline Animal ID & NBSB Tissue ID & $\begin{array}{l}\mathrm{Cu} \\
\mathrm{mg} / \mathrm{kg}\end{array}$ & $\mathbf{u}_{\mathrm{cs}}$ & $\mathbf{U}$ & $\begin{array}{l}\text { Mn } \\
\mathrm{mg} / \mathrm{kg}\end{array}$ & $\mathbf{u}_{\mathrm{cs}}$ & $\mathbf{U}$ & $\begin{array}{l}\mathrm{Br} \\
\mathrm{mg} / \mathrm{kg}\end{array}$ & $\mathbf{u}_{\mathbf{c s}}$ & $\mathbf{U}$ & $\begin{array}{l}\mathrm{Fe} \\
\mathrm{mg} / \mathrm{kg}\end{array}$ & $\mathbf{u}_{\mathrm{cs}}$ & $\mathbf{U}$ \\
\hline \multirow[t]{7}{*}{ RTDL-013 } & NM8K715.B003.A & $<2$ & -- & -- & 0.16 & 0.01 & 0.02 & 11.9 & 1.3 & 2.6 & 23 & 3 & 6 \\
\hline & NM 8K715.B003.B & $<2$ & - & - & 0.18 & 0.01 & 0.02 & 16.5 & 1.3 & 2.6 & 32 & 1 & 2 \\
\hline & NM 8K715.B003.C & - & - & - & -- & -- & - & - & - & - & 34 & 1 & 2 \\
\hline & NM 8K715.ICPMS & 1.0 & - - & 0.7 & 0.38 & -- & 0.12 & -- & - & -- & -- & - & - - \\
\hline & NM8L714.B003.A & 6.2 & 0.3 & 0.7 & 4.37 & 0.02 & 0.12 & 16.5 & 1.2 & 2.4 & 231 & 3 & 8 \\
\hline & NM 8L714.B003.B & 5.5 & 0.4 & 0.9 & 4.35 & 0.03 & 0.12 & 16.9 & 1.6 & 3.2 & 226 & 3 & 8 \\
\hline & NM 8L714.ICPMS & 7.7 & -- & 1.2 & 6.2 & -- & 0.7 & - - & -- & -- & - - & - - & - - \\
\hline \multirow[t]{6}{*}{ RTDL-014 } & NM8K718.B003.A & $<3$ & -- & - & 0.54 & 0.05 & 0.09 & 21.5 & 1.4 & 2.8 & 54 & 1 & 2 \\
\hline & NM8K718.B003.B & $<3$ & - & - & 0.58 & 0.02 & 0.05 & 23.2 & 1.6 & 3.2 & 56 & 1 & 2 \\
\hline & NM8K718.ICPMS & 3.1 & - & 0.4 & 0.76 & -- & 0.09 & - & - & - & - & -- & -- \\
\hline & NM8L717.B003.A & $<3$ & - & - & 4.66 & 0.02 & 0.12 & 17.4 & 1.2 & 2.4 & 159 & 2 & 6 \\
\hline & NM8L717.B003.B & $<3$ & - & - & 4.64 & 0.03 & 0.13 & 17.3 & 1.2 & 2.4 & 159 & 2 & 6 \\
\hline & NM8L717.ICPMS & 5.0 & -- & 0.6 & 5.2 & -- & 1.2 & -- & - & - & - & -- & -- \\
\hline \multirow[t]{6}{*}{ RTDL-015 } & NM8K721.B003.A & $<5$ & - & - & 0.49 & 0.02 & 0.05 & 18.5 & 1.7 & 3.4 & 35 & 1 & 2 \\
\hline & NM8K721.B003.B & $<5$ & - & -- & 0.44 & 0.02 & 0.04 & 16.9 & 1.5 & 3.0 & 33 & 1 & 2 \\
\hline & NM8K721.ICPMS & 2.1 & - & 1.9 & 0.64 & - & 0.42 & - & - & - & - & -- & - \\
\hline & NM8L720.B003.A & 3.6 & 0.7 & 1.3 & 5.14 & 0.03 & 0.14 & 16.4 & 1.2 & 2.4 & 185 & 2 & 6 \\
\hline & NM8L720.B003.B & 3.5 & 0.6 & 1.2 & 5.03 & 0.03 & 0.14 & 16.7 & 1.5 & 3.0 & 192 & 2 & 6 \\
\hline & NM8L720.ICPMS & 4.9 & -- & 3.3 & 7.3 & -- & 6.7 & -- & - - & -- & -- & - - & - \\
\hline
\end{tabular}

*Results are from INAA unless otherwise indicated by the NBSB Tissue ID code. 
Table B3 (Continued): Results of INAA and ICP-MS analyses of rough-toothed dolphin kidney and liver tissues. Values for mass fraction, uncertainties associated with counting statistics $\left(\mathrm{u}_{\mathrm{cs}}\right)$, and expanded uncertainties $(\mathrm{U} ; \mathrm{k}=2)$ are expressed as mg/kg of wet mass.

\begin{tabular}{|c|c|c|c|c|c|c|c|c|c|c|c|c|c|}
\hline Animal ID & NBSB Tissue ID & $\begin{array}{l}\mathrm{Co} \\
\mathrm{mg} / \mathrm{kg}\end{array}$ & $\mathbf{u}_{\mathrm{cs}}$ & $\mathbf{U}$ & $\begin{array}{l}\mathrm{Zn} \\
\mathrm{mg} / \mathrm{kg}\end{array}$ & $\mathbf{u}_{\mathrm{cs}}$ & $\mathbf{U}$ & $\begin{array}{l}\text { As } \\
\mathrm{mg} / \mathrm{kg}\end{array}$ & $\mathbf{u}_{\mathrm{cs}}$ & $\mathbf{U}$ & \begin{tabular}{|l|}
$\mathrm{Se}$ \\
$\mathrm{mg} / \mathrm{kg}$ \\
\end{tabular} & $\mathbf{u}_{\mathrm{cs}}$ & $\mathbf{U}$ \\
\hline \multirow{6}{*}{ RTDL-001 } & NM8K679.B003.A & 0.0041 & 0.0018 & 0.0036 & 15.80 & 0.08 & 0.42 & $<0.34$ & -- & -- & 2.56 & 0.02 & 0.07 \\
\hline & NM8K679.B003.B & 0.0040 & 0.0017 & 0.0034 & 15.71 & 0.08 & 0.42 & $<0.20$ & -- & -- & 2.56 & 0.02 & 0.07 \\
\hline & NM8K679.ICPMS & -- & -- & -- & 16.6 & -- & 2.1 & -- & -- & -- & -- & -- & -- \\
\hline & NM8L678B003.A & 0.0031 & 0.0002 & 0.0004 & 49.5 & 0.5 & 1.6 & 0.42 & 0.01 & 0.02 & 2.85 & 0.03 & 0.09 \\
\hline & NM8L678.B003.B & 0.0045 & 0.0003 & 0.0006 & 50.7 & 0.6 & 1.7 & 0.29 & 0.01 & 0.02 & 2.92 & 0.03 & 0.09 \\
\hline & NM8L678.ICPMS & -- & -- & -- & 56.5 & -- & 6.8 & -- & -- & -- & -- & -- & -- \\
\hline \multirow[t]{6}{*}{ RTDL-002 } & NM8K682.B003.A & 0.0094 & 0.0002 & 0.0005 & 15.47 & 0.08 & 0.41 & $<0.32$ & -- & -- & 5.91 & 0.05 & 0.18 \\
\hline & NM8K682.B003.B & 0.0081 & 0.0002 & 0.0004 & 15.67 & 0.08 & 0.42 & $<0.29$ & -- & -- & 5.89 & 0.05 & 0.18 \\
\hline & NM8K682.ICPMS & -- & -- & -- & 19.3 & -- & 5.1 & -- & -- & -- & -- & -- & -- \\
\hline & NM8L681.B003.A & 0.0079 & 0.0003 & 0.0006 & 35.7 & 0.4 & 1.2 & 0.21 & 0.01 & 0.02 & 27.96 & 0.31 & 0.92 \\
\hline & NM8L681.B003.B & 0.0084 & 0.0003 & 0.0006 & 35.1 & 0.4 & 1.2 & 0.30 & 0.02 & 0.04 & 27.25 & 0.30 & 0.90 \\
\hline & NM8L681.ICPMS & -- & -- & -- & 49.3 & -- & 38.5 & -- & - & - & -- & -- & -- \\
\hline \multirow[t]{6}{*}{ RTDL-003 } & NM8K685.B003.A & 0.0084 & 0.0002 & 0.0004 & 11.58 & 0.06 & 0.31 & $<0.44$ & -- & -- & 7.83 & 0.06 & 0.23 \\
\hline & NM8K685.B003.B & 0.0051 & 0.0002 & 0.0004 & 10.35 & 0.06 & 0.28 & $<0.33$ & -- & -- & 6.81 & 0.05 & 0.19 \\
\hline & NM8K685.ICPMS & -- & -- & -- & 14.1 & -- & 2.2 & -- & -- & -- & -- & -- & -- \\
\hline & NM8L684.B003.A & 0.0075 & 0.0004 & 0.0008 & 48.1 & 0.5 & 1.5 & 0.35 & 0.02 & 0.03 & 95.93 & 1.07 & 3.18 \\
\hline & NM8L684.B003.B & 0.0076 & 0.0004 & 0.0008 & 48.8 & 0.5 & 1.6 & 0.33 & 0.03 & 0.06 & 97.96 & 1.09 & 3.24 \\
\hline & NM8L684.ICPMS & -- & -- & -- & 56.1 & -- & 6.5 & -- & -- & -- & -- & -- & -- \\
\hline \multirow[t]{6}{*}{ RTDL-004 } & NM8K688.B003.A & 0.0090 & 0.0002 & 0.0005 & 17.13 & 0.09 & 0.30 & $<0.51$ & -- & -- & 5.06 & 0.04 & 0.15 \\
\hline & NM8K688.B003.B & 0.0089 & 0.0002 & 0.0005 & 16.92 & 0.08 & 0.29 & $<0.42$ & -- & -- & 5.04 & 0.04 & 0.15 \\
\hline & NM8K688.ICPMS & -- & -- & -- & 20.5 & -- & 3.0 & -- & -- & -- & -- & -- & -- \\
\hline & NM8L687.B003.A & 0.0095 & 0.0003 & 0.0006 & 50.5 & 0.5 & 1.6 & 0.53 & 0.02 & 0.05 & 6.59 & 0.08 & 0.23 \\
\hline & NM8L687.B003.B & 0.0095 & 0.0002 & 0.0005 & 51.7 & 0.6 & 1.7 & 0.38 & 0.02 & 0.03 & 6.78 & 0.08 & 0.23 \\
\hline & NM8L687.ICPMS & -- & -- & -- & 60.0 & -- & 30.4 & -- & -- & -- & -- & -- & -- \\
\hline \multirow[t]{6}{*}{ RTDL-005 } & NM8K691.B003.A & 0.0058 & 0.0003 & 0.0006 & 15.99 & 0.1 & 0.32 & $<0.51$ & -- & -- & 6.83 & 0.06 & 0.21 \\
\hline & NM8K691.B003.B & 0.0056 & 0.0002 & 0.0004 & 15.28 & 0.09 & 0.30 & $<0.42$ & -- & -- & 6.64 & 0.06 & 0.20 \\
\hline & NM8K691.ICPMS & -- & -- & -- & 16.1 & -- & 4.5 & -- & -- & -- & -- & -- & -- \\
\hline & NM8L690.B003.A & 0.0076 & 0.0002 & 0.0004 & 47.1 & 0.5 & 1.5 & 0.32 & 0.01 & 0.03 & 91.65 & 1.02 & 3.03 \\
\hline & NM8L690.B003.B & 0.0071 & 0.0004 & 0.0008 & 47.8 & 0.5 & 1.5 & 0.26 & 0.02 & 0.04 & 92.59 & 1.03 & 3.06 \\
\hline & NM8L690.ICPMS & -- & -- & -- & 54.0 & -- & 6.5 & -- & -- & -- & -- & -- & -- \\
\hline \multirow[t]{6}{*}{ RTDL-006 } & NM8K694.B003.A & 0.0118 & 0.0002 & 0.0005 & 18.94 & 0.09 & 0.30 & 0.62 & 0.13 & 0.26 & 5.86 & 0.05 & 0.17 \\
\hline & NM8K694.B003.B & 0.0119 & 0.0002 & 0.0005 & 18.51 & 0.09 & 0.31 & 0.40 & 0.07 & 0.14 & 5.75 & 0.04 & 0.16 \\
\hline & NM8K694.ICPMS & -- & -- & -- & 21.2 & -- & 3.7 & -- & -- & -- & -- & -- & -- \\
\hline & NM8L693.B003.A & 0.0108 & 0.0003 & 0.0007 & 44.1 & 0.5 & 1.5 & 0.50 & 0.01 & 0.03 & 13.42 & 0.15 & 0.45 \\
\hline & NM8L693.B003.B & 0.0113 & 0.0003 & 0.0007 & 44.0 & 0.5 & 1.5 & 0.52 & 0.02 & 0.04 & 13.35 & 0.15 & 0.44 \\
\hline & NM8L693.ICPMS & -- & -- & -- & 50.3 & -- & 5.9 & -- & -- & -- & -- & -- & -- \\
\hline
\end{tabular}

* Results are from INAA unless otherwise indicated by the NBSB Tissue ID code. 
Table B3 (Continued): Results of INAA and ICP-MS analyses of rough-toothed dolphin kidney and liver tissues. Values for mass fraction, uncertainties associated with counting statistics $\left(\mathrm{u}_{\mathrm{cs}}\right)$, and expanded uncertainties $(\mathrm{U} ; \mathrm{k}=2)$ are expressed as $\mathrm{mg} / \mathrm{kg}$ of wet mass.

\begin{tabular}{|c|c|c|c|c|c|c|c|c|c|c|c|c|c|}
\hline Animal ID & NBSB Tissue ID & $\begin{array}{l}\mathrm{Co} \\
\mathrm{mg} / \mathrm{kg}\end{array}$ & $\mathbf{u}_{\mathrm{cs}}$ & $\mathbf{U}$ & $\begin{array}{l}\mathrm{Zn} \\
\mathrm{mg} / \mathrm{kg}\end{array}$ & $\mathbf{u}_{\mathrm{cs}}$ & $\mathbf{U}$ & $\begin{array}{l}\text { As } \\
\text { mg/kg }\end{array}$ & $\mathbf{u}_{\mathrm{cs}}$ & $\mathbf{U}$ & $\begin{array}{l}\mathrm{Se} \\
\mathrm{mg} / \mathrm{kg}\end{array}$ & $\mathbf{u}_{\mathrm{cs}}$ & $\mathbf{U}$ \\
\hline \multirow{6}{*}{ RTDL-007 } & NM8K697.B003.A & 0.0102 & 0.0003 & 0.0006 & 15.67 & 0.09 & 0.29 & $<0.40$ & -- & -- & 11.03 & 0.09 & 0.32 \\
\hline & NM8K697.B003.B & 0.0104 & 0.0003 & 0.0007 & 15.50 & 0.08 & 0.27 & $<0.38$ & -- & -- & 11.21 & 0.09 & 0.33 \\
\hline & NM8K697.ICPMS & -- & -- & -- & 15.7 & -- & 4.2 & -- & -- & -- & -- & -- & -- \\
\hline & NM8L696.B003.A & 0.0075 & 0.0004 & 0.0008 & 31.1 & 0.3 & 1.0 & 0.52 & 0.01 & 0.03 & 89.36 & 1.00 & 2.96 \\
\hline & NM8L696.B003.B & 0.0103 & 0.0004 & 0.0008 & 32.4 & 0.4 & 1.1 & 0.66 & 0.03 & 0.06 & 93.14 & 1.04 & 3.09 \\
\hline & NM8L696.ICPMS & -- & -- & -- & 43.0 & -- & 32.7 & -- & -- & -- & -- & -- & -- \\
\hline \multirow[t]{6}{*}{ RTDL-008 } & NM8K700.B003.A & 0.0076 & 0.0002 & 0.0004 & 12.98 & 0.07 & 0.23 & 0.99 & 0.14 & 0.28 & 6.56 & 0.05 & 0.19 \\
\hline & NM8K700.B003.B & 0.0015 & 0.0003 & 0.0006 & 15.28 & 0.08 & 0.27 & 0.56 & 0.09 & 0.18 & 7.35 & 0.06 & 0.22 \\
\hline & NM8K700.ICPMS & -- & -- & -- & 16.2 & -- & 6.2 & -- & -- & -- & -- & -- & -- \\
\hline & NM8L699.B003.A & 0.0078 & 0.0003 & 0.0006 & 36.8 & 0.4 & 1.2 & 0.46 & 0.02 & 0.04 & 32.53 & 0.40 & 1.13 \\
\hline & NM8L699.B003.B & 0.0073 & 0.0003 & 0.0006 & 36.9 & 0.4 & 1.2 & 0.48 & 0.03 & 0.06 & 32.70 & 0.40 & 1.13 \\
\hline & NM8L699.ICPMS & -- & -- & -- & 49.3 & -- & 43.4 & -- & -- & -- & -- & -- & -- \\
\hline \multirow[t]{6}{*}{ RTDL-009 } & NM8K703.B003.A & 0.0067 & 0.0002 & 0.0004 & 12.77 & 0.07 & 0.23 & $<0.38$ & 0.021 & -- & 4.60 & 0.04 & 0.14 \\
\hline & NM8K703.B003.B & 0.0061 & 0.0002 & 0.0004 & 12.45 & 0.07 & 0.22 & $<0.36$ & -- & -- & 4.61 & 0.04 & 0.14 \\
\hline & NM8K703.ICPMS & -- & -- & -- & 14.5 & -- & 2.6 & -- & -- & -- & -- & -- & -- \\
\hline & NM8L702.B003.A & 0.0070 & 0.0003 & 0.0006 & 51.6 & 0.6 & 1.7 & 0.34 & 0.01 & 0.03 & 27.54 & 0.31 & .92 \\
\hline & NM8L702.B003.B & 0.0072 & 0.0003 & 0.0006 & 50.4 & 0.5 & 1.6 & 0.31 & 0.02 & 0.05 & 26.88 & 0.30 & 0.89 \\
\hline & NM8L702.ICPMS & -- & -- & -- & 68.3 & -- & 20.3 & -- & -- & -- & -- & -- & -- \\
\hline \multirow{6}{*}{ RTDL-010 } & NM8K706.B003.A & 0.0104 & 0.001 & 0.0020 & 16.04 & 0.08 & 0.28 & $<0.35$ & -- & -- & 5.68 & 0.04 & 0.16 \\
\hline & NM8K706.B003.B & 0.0157 & 0.001 & 0.0020 & 14.88 & 0.08 & 0.26 & $<0.29$ & -- & -- & 5.25 & 0.04 & 0.15 \\
\hline & NM8K706.ICPMS & -- & -- & -- & 16.9 & -- & 2.8 & -- & -- & -- & -- & -- & -- \\
\hline & NM8L705.B003.A & 0.0099 & 0.0003 & 0.0007 & 42.6 & 0.5 & 1.4 & 0.36 & 0.02 & 0.04 & 18.35 & 0.21 & 0.62 \\
\hline & NM8L705.B003.B & 0.0096 & 0.0003 & 0.0006 & 42.5 & 0.5 & 1.4 & 0.33 & 0.02 & 0.05 & 18.31 & 0.21 & 0.61 \\
\hline & NM8L705.ICPMS & -- & -- & -- & 50.6 & -- & 7.6 & -- & -- & -- & -- & -- & -- \\
\hline \multirow[t]{6}{*}{ RTDL-011 } & NM8K709.B003.A & 0.0137 & 0.0003 & 0.0007 & 16.90 & 0.09 & 0.30 & 0.51 & 0.13 & 0.26 & 5.82 & 0.05 & 0.17 \\
\hline & NM8K709.B003.B & 0.0096 & 0.0002 & 0.0005 & 16.17 & 0.08 & 0.28 & 0.38 & 0.07 & 0.14 & 5.53 & 0.04 & 0.16 \\
\hline & NM8K709.ICPMS & -- & -- & -- & 19.0 & -- & 3.3 & -- & -- & -- & -- & -- & -- \\
\hline & NM8L708.B003.A & 0.0103 & 0.0003 & 0.0007 & 43.8 & 0.5 & 1.5 & 0.37 & 0.002 & 0.04 & 7.34 & 0.08 & 0.24 \\
\hline & NM8L708.B003.B & 0.01005 & 0.0003 & 0.0007 & 43.6 & 0.5 & 1.5 & 0.49 & 0.03 & 0.07 & 7.27 & 0.08 & 0.24 \\
\hline & NM8L708.ICPMS & -- & -- & -- & 73.1 & -- & 108 & -- & - & -- & - & -- & -- \\
\hline \multirow[t]{6}{*}{ RTDL-012 } & NM8K712.B003.A & 0.0184 & 0.0003 & 0.0008 & 17.39 & 0.09 & 0.30 & $<0.35$ & -- & -- & 2.50 & 0.02 & 0.07 \\
\hline & NM8K712.B003.B & 0.0057 & 0.0002 & 0.0004 & 17.02 & 0.09 & 0.30 & $<0.22$ & -- & -- & 2.41 & 0.02 & 0.07 \\
\hline & NM8K712.ICPMS & -- & -- & -- & 20.7 & -- & 3.6 & -- & -- & -- & -- & -- & -- \\
\hline & NM8L711.B003.A & 0.0046 & 0.0002 & 0.0004 & 46.8 & 0.5 & 1.5 & 0.44 & 0.02 & 0.04 & 3.02 & 0.04 & 0.11 \\
\hline & NM8L711.B003.B & 0.0046 & 0.0003 & 0.0006 & 46.2 & 0.5 & 1.5 & 0.41 & 0.03 & 0.06 & 2.96 & 0.04 & 0.11 \\
\hline & NM8L711.ICPMS & -- & -- & -- & 51.0 & -- & 5.9 & -- & -- & -- & -- & -- & -- \\
\hline
\end{tabular}

*Results are from INAA unless otherwise indicated by the NBSB Tissue ID code. 
Table B3 (Continued): Results of INAA and ICP-MS analyses of rough-toothed dolphin kidney and liver tissues. Values for mass fraction, uncertainties associated with counting statistics $\left(\mathrm{u}_{\mathrm{cs}}\right)$, and expanded uncertainties $(\mathrm{U} ; \mathrm{k}=2)$ are expressed as $\mathrm{mg} / \mathrm{kg}$ of wet mass.

\begin{tabular}{|c|c|c|c|c|c|c|c|c|c|c|c|c|c|}
\hline Animal ID & NBSB Tissue ID & $\begin{array}{l}\mathrm{Co} \\
\mathrm{mg} / \mathrm{kg}\end{array}$ & $\mathbf{u}_{\mathrm{cs}}$ & $\mathbf{U}$ & $\begin{array}{l}\mathrm{Zn} \\
\mathrm{mg} / \mathrm{kg}\end{array}$ & $\mathbf{u}_{\mathrm{cs}}$ & $\mathbf{U}$ & $\begin{array}{l}\text { As } \\
\mathrm{mg} / \mathrm{kg}\end{array}$ & $\mathbf{u}_{\mathrm{cs}}$ & $\mathbf{U}$ & $\begin{array}{l}\mathrm{Se} \\
\mathrm{mg} / \mathrm{kg}\end{array}$ & $\mathbf{u}_{\mathrm{cs}}$ & $\mathbf{U}$ \\
\hline \multirow[t]{7}{*}{ RTDL-013 } & NM8K715.B003.A & 0.0055 & 0.0012 & 0.0024 & 6.44 & 0.03 & 0.11 & 0.58 & 0.04 & 0.08 & 5.90 & 0.04 & 0.17 \\
\hline & NM 8K715.B003.B & 0.0077 & 0.0014 & 0.0028 & 9.41 & 0.05 & 0.17 & 0.74 & 0.05 & 0.10 & 8.42 & 0.06 & 0.24 \\
\hline & NM 8K715.B003.C & 0.0094 & 0.0018 & 0.0036 & 9.90 & 0.05 & 0.17 & 0.88 & 0.05 & 0.10 & 8.78 & 0.07 & 0.26 \\
\hline & NM 8K715.ICPMS & -- & -- & -- & 10.6 & -- & 4.0 & -- & -- & -- & -- & -- & -- \\
\hline & NM8L714.B003.A & 0.0084 & 0.0004 & 0.0008 & 37.4 & 0.4 & 1.2 & 0.38 & 0.02 & 0.04 & 124.9 & 1.4 & 4.2 \\
\hline & NM 8L714.B003.B & 0.0080 & 0.0005 & 0.0010 & 35.7 & 0.4 & 1.2 & 0.55 & 0.04 & 0.08 & 118.9 & 1.3 & 3.9 \\
\hline & NM 8L714.ICPMS & -- & -- & -- & 46.0 & -- & 7.2 & & & & & & \\
\hline \multirow[t]{6}{*}{ RTDL-014 } & NM8K718.B003.A & 0.0076 & 0.0002 & 0.0004 & 18.04 & 0.09 & 0.31 & 0.13 & 0.01 & -- & 5.03 & 0.04 & 0.15 \\
\hline & NM8K718.B003.B & 0.0078 & 0.0002 & 0.0004 & 19.06 & 0.1 & 0.34 & $<0.19$ & -- & -- & 5.34 & 0.04 & 0.15 \\
\hline & NM8K718.ICPMS & -- & -- & -- & 19.3 & -- & 2.4 & -- & -- & -- & -- & -- & -- \\
\hline & NM8L717.B003.A & 0.0072 & 0.0003 & 0.0006 & 51.7 & 0.6 & 1.7 & 0.61 & 0.03 & 0.07 & 8.42 & 0.10 & 0.29 \\
\hline & NM8L717.B003.B & 0.0070 & 0.0002 & 0.0004 & 51.7 & 0.6 & 1.7 & 0.59 & 0.03 & 0.07 & 8.41 & 0.10 & 0.29 \\
\hline & NM8L717.ICPMS & -- & -- & -- & 52.4 & -- & 8.3 & & & & & & \\
\hline \multirow[t]{6}{*}{ RTDL-015 } & NM8K721.B003.A & 0.0092 & 0.0002 & 0.0005 & 17.23 & 0.09 & 0.30 & $<0.35$ & -- & -- & 2.82 & 0.02 & 0.08 \\
\hline & NM8K721.B003.B & 0.0073 & 0.0002 & 0.0004 & 16.65 & 0.08 & 0.28 & $<0.26$ & -- & -- & 2.69 & 0.02 & 0.08 \\
\hline & NM8K721.ICPMS & -- & -- & -- & 19.9 & -- & 13.7 & -- & -- & -- & -- & -- & -- \\
\hline & NM8L720.B003.A & 0.0089 & 0.0003 & 0.0006 & 61.1 & 0.7 & 2.0 & 0.49 & 0.02 & 0.05 & 8.86 & 0.10 & 0.30 \\
\hline & NM8L720.B003.B & 0.0092 & 0.0003 & 0.0006 & 62.0 & 0.7 & 2.1 & 0.44 & 0.03 & 0.06 & 9.09 & 0.10 & 0.30 \\
\hline & NM8L720.ICPMS & -- & -- & -- & 77.2 & -- & 62.2 & & & & & & \\
\hline
\end{tabular}

*Results are from INAA unless otherwise indicated by the NBSB Tissue ID code. 
Table B3 (Continued): Results of INAA and ICP-MS analyses of rough-toothed dolphin kidney and liver tissues. Values for mass fraction, uncertainties associated with counting statistics $\left(\mathrm{u}_{\mathrm{cs}}\right)$, and expanded uncertainties $(\mathrm{U} ; \mathrm{k}=2)$ are expressed as mg/kg of wet mass.

\begin{tabular}{|c|c|c|c|c|c|c|c|c|c|c|}
\hline Animal ID & NBSB Tissue ID & $\begin{array}{l}\text { Rb } \\
\mathrm{mg} / \mathrm{kg}\end{array}$ & $\mathbf{u}_{\mathrm{cs}}$ & $\mathbf{U}$ & $\begin{array}{l}\mathrm{Ag} \\
\mathrm{mg} / \mathrm{kg}\end{array}$ & $\mathbf{u}_{\mathrm{cs}}$ & $\mathbf{U}$ & $\begin{array}{l}\mathrm{Cs} \\
\mathrm{mg} / \mathrm{kg} \\
\end{array}$ & $\mathbf{u}_{\mathrm{cs}}$ & $\mathbf{U}$ \\
\hline \multirow{6}{*}{ RTDL-001 } & NM8K679.B003.A & 1.23 & 0.13 & 0.25 & $<0.006$ & -- & -- & 0.049 & 0.001 & 0.002 \\
\hline & NM8K679.B003.B & 1.16 & 0.12 & 0.24 & $<0.006$ & - - & - - & 0.042 & 0.001 & 0.002 \\
\hline & NM8K679.ICPMS & - & -- & -- & $<0.02$ & - & - & -- & -- & -- \\
\hline & NM8L678B003.A & 1.17 & 0.04 & 0.08 & 0.043 & 0.004 & 0.008 & 0.0307 & 0.0014 & 0.0029 \\
\hline & NM8L678.B003.B & 1.24 & 0.05 & 0.09 & 0.055 & 0.003 & 0.006 & 0.0305 & 0.0012 & 0.0025 \\
\hline & NM8L678.ICPMS & -- & -- & -- & 0.06 & -- & 0.01 & - - & -- & - - \\
\hline \multirow[t]{6}{*}{ RTDL-002 } & NM8K682.B003.A & 0.96 & 0.10 & 0.20 & $<0.006$ & - & -- & 0.042 & 0.003 & 0.006 \\
\hline & NM8K682.B003.B & 0.88 & 0.09 & 0.18 & $<0.006$ & - & - & 0.042 & 0.001 & 0.002 \\
\hline & NM8K682.ICPMS & -- & -- & -- & $<0.02$ & - & - & -- & -- & -- \\
\hline & NM8L681.B003.A & 0.75 & 0.03 & 0.06 & 0.572 & 0.006 & 0.018 & 0.0335 & 0.0011 & 0.0023 \\
\hline & NM8L681.B003.B & 0.78 & 0.03 & 0.06 & 0.564 & 0.006 & 0.018 & 0.0333 & 0.0012 & 0.0025 \\
\hline & NM8L681.ICPMS & -- & - - & -- & 0.76 & - - & 0.49 & - - & - - & - \\
\hline \multirow[t]{6}{*}{ RTDL-003 } & NM8K685.B003.A & 0.77 & 0.08 & 0.16 & $<0.006$ & - - & - & 0.045 & 0.001 & 0.002 \\
\hline & NM8K685.B003.B & 0.63 & 0.07 & 0.14 & $<0.006$ & - & - & 0.040 & 0.001 & 0.002 \\
\hline & NM8K685.ICPMS & -- & -- & -- & $<0.02$ & - & - & -- & -- & -- \\
\hline & NM8L684.B003.A & 1.01 & 0.04 & 0.09 & 0.886 & 0.008 & 0.027 & 0.0455 & 0.0015 & 0.0032 \\
\hline & NM8L684.B003.B & 0.85 & 0.04 & 0.07 & 0.918 & 0.008 & 0.028 & 0.0481 & 0.0017 & 0.0036 \\
\hline & NM8L684.ICPMS & - & -- & -- & 1.06 & - - & 0.13 & - - & - - & - - \\
\hline \multirow[t]{6}{*}{ RTDL-004 } & NM8K688.B003.A & 0.97 & 0.10 & 0.20 & 0.012 & 0.002 & 0.004 & 0.032 & 0.001 & 0.002 \\
\hline & NM8K688.B003.B & 0.88 & 0.09 & 0.19 & 0.008 & 0.002 & 0.004 & 0.031 & 0.001 & 0.002 \\
\hline & NM8K688.ICPMS & -- & -- & -- & $<0.02$ & - - & - - & - - & - - & - - \\
\hline & NM8L687.B003.A & 1.00 & 0.03 & 0.07 & 0.185 & 0.004 & 0.009 & 0.0265 & 0.0013 & 0.0027 \\
\hline & NM8L687.B003.B & 1.05 & 0.03 & 0.07 & 0.185 & 0.004 & 0.009 & 0.0267 & 0.0012 & 0.0025 \\
\hline & NM8L687.ICPMS & -- & - - & -- & 0.23 & - - & 0.07 & - - & - - & - - \\
\hline \multirow[t]{6}{*}{ RTDL-005 } & NM8K691.B003.A & 0.78 & 0.08 & 0.17 & $<0.006$ & - & - & 0.040 & 0.001 & 0.002 \\
\hline & NM8K691.B003.B & 0.71 & 0.08 & 0.15 & $<0.006$ & - & - - & 0.039 & 0.001 & 0.002 \\
\hline & NM8K691.ICPMS & - & - - & - & $<0.02$ & - - & - - & - - & - & - - \\
\hline & NM8L690.B003.A & 0.97 & 0.04 & 0.08 & 1.002 & 0.008 & 0.029 & 0.0347 & 0.0015 & 0.0031 \\
\hline & NM8L690.B003.B & 0.91 & 0.04 & 0.08 & 1.008 & 0.008 & 0.029 & 0.0350 & 0.0013 & 0.0027 \\
\hline & NM8L690.ICPMS & - - & -- & - - & 1.14 & - & 0.13 & -- & -- & - \\
\hline \multirow[t]{6}{*}{ RTDL-006 } & NM8K694.B003.A & 1.33 & 0.14 & 0.28 & 0.017 & 0.002 & 0.004 & 0.049 & 0.001 & 0.002 \\
\hline & NM8K694.B003.B & 1.31 & 0.14 & 0.27 & 0.013 & 0.002 & 0.004 & 0.048 & 0.001 & 0.002 \\
\hline & NM8K694.ICPMS & -- & -- & -- & $<0.02$ & - - & - - & -- & -- & - - \\
\hline & NM8L693.B003.A & 1.07 & 0.03 & 0.07 & 0.677 & 0.006 & 0.020 & 0.0240 & 0.0012 & 0.0025 \\
\hline & NM8L693.B003.B & 0.99 & 0.04 & 0.08 & 0.672 & 0.007 & 0.022 & 0.0253 & 0.0012 & 0.0025 \\
\hline & NM8L693.ICPMS & -- & -- & -- & 0.80 & - - & 0.09 & -- & -- & -- \\
\hline
\end{tabular}

*Results are from INAA unless otherwise indicated by the NBSB Tissue ID code. 
Table B3 (Continued): Results of INAA and ICP-MS analyses of rough-toothed dolphin kidney and liver tissues. Values for mass fraction, uncertainties associated with counting statistics $\left(\mathrm{u}_{\mathrm{cs}}\right)$, and expanded uncertainties $(\mathrm{U} ; \mathrm{k}=2)$ are expressed as mg/kg of wet mass.

\begin{tabular}{|c|c|c|c|c|c|c|c|c|c|c|}
\hline Animal ID & NBSB Tissue ID & $\begin{array}{l}\mathrm{Rb} \\
\mathrm{mg} / \mathrm{kg}\end{array}$ & $\mathbf{u}_{\mathrm{cs}}$ & $\mathbf{U}$ & $\begin{array}{l}\mathrm{Ag} \\
\mathrm{mg} / \mathrm{kg}\end{array}$ & $\mathbf{u}_{\mathrm{cs}}$ & $\mathbf{U}$ & $\begin{array}{l}\mathrm{Cs} \\
\mathrm{mg} / \mathrm{kg}\end{array}$ & $\mathbf{u}_{\mathrm{cs}}$ & $\mathbf{U}$ \\
\hline \multirow[t]{6}{*}{ RTDL-007 } & NM8K697.B003.A & 1.02 & 0.11 & 0.21 & $<0.006$ & - & -- & 0.060 & 0.001 & 0.002 \\
\hline & NM8K697.B003.B & 0.98 & 0.10 & 0.21 & $<0.006$ & - & - & 0.061 & 0.001 & 0.002 \\
\hline & NM8K697.ICPMS & -- & -- & - & $<0.02$ & - & - & - & - & - - \\
\hline & NM8L696.B003.A & 1.41 & 0.04 & 0.09 & 0.732 & 0.007 & 0.023 & 0.0877 & 0.0019 & 0.0044 \\
\hline & NM8L696.B003.B & 1.46 & 0.05 & 0.10 & 0.764 & 0.007 & 0.023 & 0.0901 & 0.0015 & 0.0037 \\
\hline & NM8L696.ICPMS & -- & -- & -- & 0.99 & -- & 0.78 & -- & -- & -- \\
\hline \multirow{6}{*}{ RTDL-008 } & NM8K700.B003.A & 0.78 & 0.08 & 0.16 & $<0.006$ & - & -- & 0.030 & 0.001 & 0.002 \\
\hline & NM8K700.B003.B & 0.82 & 0.09 & 0.17 & $<0.006$ & - & - & 0.037 & 0.001 & 0.002 \\
\hline & NM8K700.ICPMS & - & - - & - & $<0.02$ & - - & - - & - & - & - - \\
\hline & NM8L699.B003.A & 0.93 & 0.03 & 0.07 & 0.667 & 0.006 & 0.020 & 0.0266 & 0.0011 & 0.0023 \\
\hline & NM8L699.B003.B & 0.89 & 0.03 & 0.07 & 0.656 & 0.006 & 0.020 & 0.0287 & 0.0012 & 0.0025 \\
\hline & NM8L699.ICPMS & -- & -- & -- & 0.88 & -- & 0.66 & - & - & - \\
\hline \multirow{6}{*}{ RTDL-009 } & NM8K703.B003.A & 0.97 & 0.10 & 0.20 & $<0.006$ & - & -- & 0.036 & 0.001 & 0.002 \\
\hline & NM8K703.B003.B & 0.88 & 0.09 & 0.19 & $<0.006$ & - & - & 0.035 & 0.001 & 0.002 \\
\hline & NM8K703.ICPMS & - & -- & -- & $<0.02$ & - & - & - & - - & - - \\
\hline & NM8L702.B003.A & 0.94 & 0.03 & 0.06 & 0.532 & 0.006 & 0.018 & 0.0275 & 0.0012 & 0.0025 \\
\hline & NM8L702.B003.B & 0.93 & 0.03 & 0.07 & 0.513 & 0.005 & 0.016 & 0.0267 & 0.0011 & 0.0023 \\
\hline & NM8L702.ICPMS & - & - - & - & 0.69 & - - & 0.15 & - - & - - & - - \\
\hline \multirow{6}{*}{ RTDL-010 } & NM8K706.B003.A & 1.09 & 0.11 & 0.23 & $<0.006$ & - - & -- & 0.034 & 0.001 & 0.002 \\
\hline & NM8K706.B003.B & 1.01 & 0.11 & 0.21 & $<0.006$ & - & - - & 0.031 & 0.001 & 0.002 \\
\hline & NM8K706.ICPMS & -- & -- & -- & $<0.02$ & - & - & - & -- & - \\
\hline & NM8L705.B003.A & 1.00 & 0.03 & 0.07 & 0.503 & 0.005 & 0.016 & 0.0235 & 0.0012 & 0.0025 \\
\hline & NM8L705.B003.B & 0.97 & 0.04 & 0.08 & 0.503 & 0.005 & 0.016 & 0.0230 & 0.0011 & 0.0023 \\
\hline & NM8L705.ICPMS & -- & -- & -- & 0.61 & -- & 0.07 & -- & - & - \\
\hline \multirow[t]{6}{*}{ RTDL-011 } & NM8K709.B003.A & 1.33 & 0.14 & 0.28 & $<0.006$ & - & -- & 0.039 & 0.001 & 0.002 \\
\hline & NM8K709.B003.B & 1.16 & 0.16 & 0.24 & 0.055 & 0.001 & 0.003 & 0.037 & 0.001 & 0.002 \\
\hline & NM8K709.ICPMS & - & -- & -- & $<0.02$ & -- & -- & - & - & - \\
\hline & NM8L708.B003.A & 1.24 & 0.04 & 0.08 & 0.229 & 0.004 & 0.010 & 0.0271 & 0.0010 & 0.0021 \\
\hline & NM8L708.B003.B & 1.23 & 0.04 & 0.08 & 0.225 & 0.004 & 0.010 & 0.0256 & 0.0012 & 0.0025 \\
\hline & NM8L708.ICPMS & - - & - & -- & 0.30 & - & 0.21 & - - & - - & - - \\
\hline \multirow{6}{*}{ RTDL-012 } & NM8K712.B003.A & 1.37 & 0.14 & 0.28 & $<0.006$ & - & -- & 0.069 & 0.001 & 0.002 \\
\hline & NM8K712.B003.B & 1.33 & 0.14 & 0.28 & 0.0085 & 0.0016 & 0.0032 & 0.068 & 0.001 & 0.002 \\
\hline & NM8K712.ICPMS & - & -- & - - & $<0.02$ & - - & - - & - - & - - & - - \\
\hline & NM8L711.B003.A & 1.72 & 0.05 & 0.11 & 0.101 & 0.004 & 0.008 & 0.0504 & 0.0016 & 0.0034 \\
\hline & NM8L711.B003.B & 1.66 & 0.06 & 0.12 & 0.096 & 0.004 & 0.008 & 0.0490 & 0.0016 & 0.0034 \\
\hline & NM8L711.ICPMS & - & - & - & & -- & & - - & - - & - - \\
\hline
\end{tabular}

*Results are from INAA unless otherwise indicated by the NBSB Tissue ID code. 
Table B3 (Continued): Results of INAA and ICP-MS analyses of rough-toothed dolphin kidney and liver tissues. Values for mass fraction, uncertainties associated with counting statistics $\left(\mathrm{u}_{\mathrm{cs}}\right)$, and expanded uncertainties $(\mathrm{U} ; \mathrm{k}=2)$ are expressed as $\mathrm{mg} / \mathrm{kg}$ of $\mathrm{wet}$ mass.

\begin{tabular}{|c|c|c|c|c|c|c|c|c|c|c|}
\hline Animal ID & NBSB Tissue ID & $\begin{array}{l}\mathrm{Rb} \\
\mathrm{mg} / \mathrm{kg}\end{array}$ & $\mathbf{U}_{\mathrm{CS}}$ & $\mathbf{U}$ & $\begin{array}{l}\mathrm{Ag} \\
\mathrm{mg} / \mathrm{kg}\end{array}$ & $\mathbf{U}_{\mathrm{CS}}$ & $\mathbf{U}$ & $\begin{array}{l}\mathrm{Cs} \\
\mathrm{mg} / \mathrm{kg} \\
\end{array}$ & $\mathbf{U}_{\mathrm{CS}}$ & $\mathbf{U}$ \\
\hline \multirow[t]{7}{*}{ RTDL-013 } & NM8K715.B003.A & 0.31 & 0.03 & 0.07 & 0.0033 & 0.0007 & 0.001 & 0.025 & 0.001 & 0.002 \\
\hline & NM 8K715.B003.B & 0.44 & 0.05 & 0.09 & 0.0045 & 0.0006 & 0.001 & 0.036 & 0.001 & 0.002 \\
\hline & NM 8K715.B003.C & 0.47 & 0.05 & 0.10 & $<0.004$ & - & - & 0.038 & 0.001 & 0.002 \\
\hline & NM 8K715.ICPMS & -- & -- & - - & $<0.02$ & -- & -- & -- & -- & -- \\
\hline & NM8L714.B003.A & 0.94 & 0.04 & 0.09 & 1.21 & 0.01 & 0.04 & 0.0692 & 0.0016 & 0.0036 \\
\hline & NM 8L714.B003.B & 0.93 & 0.04 & 0.09 & 1.16 & 0.01 & 0.03 & 0.0698 & 0.0017 & 0.0038 \\
\hline & NM 8L714.ICPMS & - & -- & -- & 1.46 & - & 0.21 & - & - & - \\
\hline \multirow[t]{6}{*}{ RTDL-014 } & NM8K718.B003.A & 1.06 & 0.11 & 0.22 & 0.018 & 0.002 & 0.004 & 0.041 & 0.001 & 0.002 \\
\hline & NM8K718.B003.B & 1.09 & 0.11 & 0.23 & 0.021 & 0.002 & 0.003 & 0.044 & 0.001 & 0.002 \\
\hline & NM8K718.ICPMS & - & -- & -- & $<0.02$ & - & - & - & - & - \\
\hline & NM8L717.B003.A & 1.17 & 0.04 & 0.08 & 0.257 & 0.004 & 0.010 & 0.0333 & 0.0013 & 0.0027 \\
\hline & NM8L717.B003.B & 1.21 & 0.04 & 0.08 & 0.260 & 0.005 & 0.012 & 0.0346 & 0.0012 & 0.0025 \\
\hline & NM8L717.ICPMS & - & - & - & 0.29 & - - & 0.04 & -- & -- & - - \\
\hline \multirow[t]{6}{*}{ RTDL-015 } & NM8K721.B003.A & 0.80 & 0.08 & 0.17 & $<0.004$ & - & - & 0.026 & 0.001 & 0.002 \\
\hline & NM8K721.B003.B & 0.76 & 0.08 & 0.16 & $<0.004$ & - & - & 0.024 & 0.001 & 0.002 \\
\hline & NM8K721.ICPMS & - & -- & -- & $<0.02$ & - & - & - & - & - \\
\hline & NM8L720.B003.A & 1.04 & 0.04 & 0.08 & 0.150 & 0.004 & 0.009 & 0.0245 & 0.0013 & 0.0027 \\
\hline & NM8L720.B003.B & 1.00 & 0.04 & 0.08 & 0.147 & 0.005 & 0.011 & 0.0262 & 0.0012 & 0.0025 \\
\hline & NM8L720.ICPMS & -- & -- & -- & 0.19 & -- & 0.13 & -- & -- & -- \\
\hline
\end{tabular}

*Results are from INAA unless otherwise indicated by the NBSB Tissue ID code. 
Table B3 (Continued): Results of ICP-MS analyses of rough-toothed dolphin kidney and liver tissues. Values for mass fraction and expanded uncertainties $(\mathrm{U} ; \mathrm{k}=2)$ are expressed as $\mathrm{mg} / \mathrm{kg}$ of wet mass.

\begin{tabular}{|cl|cc|cc|cc|}
\hline Animal ID & NBSB Tissue ID & Cd & $\mathbf{( U )}$ & Sn & $\mathbf{( U )}$ & Hg & (U) \\
\hline RTDL-001 & NM8K679.ICPMS & 0.05 & 0.01 & $<0.02$ & -- & 0.9 & 0.1 \\
& NM8L678.ICPMS & 0.01 & 0.003 & 0.08 & 0.06 & 3.4 & 0.8 \\
RTDL-002 & NM8K682.ICPMS & 2.44 & 0.31 & 0.05 & 0.23 & 7.7 & 2.1 \\
& NM8L681.ICPMS & 0.79 & 0.20 & 0.43 & 0.28 & 52.3 & 14.9 \\
RTDL-003 & NM8K685.ICPMS & 1.18 & 0.16 & 0.05 & 0.07 & 12.8 & 1.5 \\
& NM8L684.ICPMS & 0.69 & 0.09 & 0.74 & 0.09 & 174.7 & 20.3 \\
RTDL-004 & NM8K688.ICPMS & 2.56 & 0.30 & $<0.02$ & -- & 2.1 & 0.3 \\
& NM8L687.ICPMS & 0.38 & 0.06 & 0.37 & 0.11 & 7.9 & 1.7 \\
RTDL-005 & NM8K691.ICPMS & 0.83 & 0.20 & 0.05 & 0.08 & 9.6 & 1.7 \\
& NM8L690.ICPMS & 0.72 & 0.09 & 0.78 & 0.32 & 179.8 & 26.6 \\
RTDL-006 & NM8K694.ICPMS & 3.94 & 0.46 & 0.14 & 0.31 & 4.0 & 0.7 \\
& NM8L693.ICPMS & 0.85 & 0.12 & 0.38 & 0.07 & 22.6 & 2.6 \\
RTDL-007 & NM8K697.ICPMS & 1.89 & 0.32 & 0.04 & 0.01 & 14.9 & 1.7 \\
& NM8L696.ICPMS & 0.63 & 0.17 & 0.87 & 0.57 & 176.8 & 51.0 \\
RTDL-008 & NM8K700.ICPMS & 2.25 & 0.36 & 0.04 & 0.06 & 5.6 & 0.9 \\
& NM8L699.ICPMS & 0.79 & 0.17 & 0.55 & 0.68 & 66.2 & 16.1 \\
RTDL-009 & NM8K703.ICPMS & 1.09 & 0.14 & 0.06 & 0.10 & 4.0 & 0.7 \\
& NM8L702.ICPMS & 0.38 & 0.07 & 0.39 & 0.20 & 56.4 & 11.2 \\
RTDL-010 & NM8K706.ICPMS & 2.03 & 0.26 & 0.02 & 0.03 & 3.3 & 0.5 \\
& NM8L705.ICPMS & 1.02 & 0.12 & 0.35 & 0.32 & 31.5 & 4.8 \\
RTDL-011 & NM8K709.ICPMS & 2.90 & 0.33 & 0.03 & 0.09 & 2.1 & 0.9 \\
& NM8L708.ICPMS & 0.61 & 0.23 & 0.42 & 0.65 & 12.0 & 10.1 \\
RTDL-012 & NM8K712.ICPMS & 0.12 & 0.17 & 0.01 & 0.05 & 1.0 & 0.7 \\
& NM8L711.ICPMS & 0.03 & 0.02 & 0.14 & 0.23 & 3.4 & 0.5 \\
RTDL-013 & NM8K715.ICPMS & 0.83 & 0.12 & 0.13 & 0.14 & 14.3 & 5.8 \\
& NM8L714.ICPMS & 0.65 & 0.08 & 1.10 & 0.19 & 235.2 & 36.3 \\
RTDL-014 & NM8K718.ICPMS & 2.45 & 0.30 & 0.02 & 0.05 & 2.9 & 0.4 \\
& NM8L717.ICPMS & 0.23 & 0.03 & 0.29 & 0.07 & 11.2 & 1.4 \\
RTDL-015 & NM8K721.ICPMS & 1.44 & 0.16 & $<0.02$ & -- & 1.7 & 1.2 \\
& NM8L720.ICPMS & 0.25 & 0.11 & 0.22 & 0.35 & 13.0 & 3.6 \\
\hline
\end{tabular}


Table B4: Results of INAA of control materials included with analyses of kidney tissues. Values for SRM 1566a Oyster Tissue are expressed in $\mathrm{mg} / \mathrm{kg}$ of dry mass and those for the QA Pilot Whale Liver Tissue Homogenate are expressed in $\mathrm{mg} / \mathrm{kg}$ of wet mass. Uncertainties represent the combined total uncertainty.

\begin{tabular}{|c|c|c|c|c|c|c|}
\hline & $\begin{array}{c}\text { Whale Liver } \\
\text { Homogenate } 1 \\
\text { Aliquot } 1\end{array}$ & $\begin{array}{l}\text { Assigned } \\
\text { Values }\end{array}$ & $\begin{array}{l}\text { SRM 1566a } \\
\text { Aliquot } 1\end{array}$ & $\begin{array}{l}\text { SRM 1566a } \\
\text { Aliquot } 2\end{array}$ & $\begin{array}{l}\text { Average } \\
\text { Value }\end{array}$ & $\begin{array}{l}\text { Certified } \\
\text { Values }\end{array}$ \\
\hline $\mathrm{Na}$ & $1268 \pm 45$ & $1260 \pm 30$ & $4190 \pm 110$ & $3950 \pm 126$ & 4070 & $4170 \pm 130$ \\
\hline Mg & $129 \pm 20$ & $140 \pm 5$ & $1200 \pm 163$ & $1150 \pm 162$ & 1175 & $1180 \pm 170$ \\
\hline $\mathrm{Cl}$ & $1720 \pm 53$ & $1730 \pm 40$ & $8360 \pm 248$ & $8320 \pm 247$ & 8340 & $8290 \pm 140$ \\
\hline $\mathbf{K}$ & $2713 \pm 40$ & $2640 \pm 70$ & $8230 \pm 284$ & $7810 \pm 263$ & 8020 & $7900 \pm 470$ \\
\hline $\mathbf{C a}$ & $39 \pm 12$ & $46 \pm 3$ & $1920 \pm 111$ & $1850 \pm 110$ & 1885 & $1960 \pm 190$ \\
\hline $\mathbf{V}$ & $\leq 0.02$ & $\leq 0.03$ & $4.85 \pm 0.22$ & $4.75 \pm 0.21$ & 4.80 & $4.68 \pm 0.15$ \\
\hline Mn & $3.14 \pm 0.29$ & $2.81 \pm 0.10$ & $12.2 \pm 0.5$ & $12.0 \pm 1.4$ & 12.1 & $12.3 \pm 1.5$ \\
\hline $\mathbf{C u}$ & $\leq 4$ & $2.96 \pm 0.55$ & $75 \pm 10$ & $71 \pm 10$ & 73 & $66.3 \pm 4.3$ \\
\hline $\mathrm{Br}$ & $13.6 \pm 3$ & $13.7 \pm 0.6$ & $64.1 \pm 4$ & $64.5 \pm 12$ & 64 & Not certified \\
\hline I & $\leq 2$ & $\leq 1$ & $\leq 6$ & $\leq 7$ & $\leq 7$ & $4.46 \pm 0.42$ \\
\hline Sc & $\leq 0.001$ & $\leq 0.08$ & $0.054 \pm 0.002$ & $0.055 \pm 0.002$ & 0.055 & $(0.06)$ \\
\hline $\mathbf{F e}$ & $448 \pm 15$ & $438 \pm 10$ & $532 \pm 18$ & $518 \pm 17$ & 525 & $539 \pm 15$ \\
\hline Co & $0.014 \pm 0.001$ & $0.014 \pm 0.001$ & $0.513 \pm 0.014$ & $0.500 \pm 0.014$ & 0.51 & $0.57 \pm 0.11$ \\
\hline $\mathbf{Z n}$ & $32.5 \pm 0.9$ & $32.2 \pm 0.7$ & $820 \pm 22$ & $830 \pm 23$ & 825 & $830 \pm 57$ \\
\hline As & $0.33 \pm 0.24$ & $0.53 \pm 0.02$ & $13.7 \pm 0.4$ & $14.5 \pm 0.4$ & 14.1 & $14.0 \pm 1.2$ \\
\hline Se & $11.6 \pm 0.4$ & $11.0 \pm 0.3$ & $2.18 \pm 0.10$ & $2.15 \pm 0.10$ & 2.17 & $2.21 \pm 0.24$ \\
\hline $\mathbf{R b}$ & $1.9 \pm 0.4$ & $2.00 \pm 0.06$ & $3.3 \pm 0.8$ & $3.2 \pm 0.8$ & 3.24 & (3) \\
\hline $\mathbf{S r}$ & $\leq 1.1$ & $\leq 0.8$ & Not analyzed & Not analyzed & -- & $11.1 \pm 1.0$ \\
\hline Mo & $\leq 0.9$ & $\leq 0.4$ & $\leq 2$ & $\leq 2$ & $\leq 2$ & Not certified \\
\hline Ag & $0.183 \pm 0.011$ & $0.181 \pm 0.005$ & $1.65 \pm 0.06$ & $1.69 \pm 0.09$ & 1.67 & $1.68 \pm 0.15$ \\
\hline Cd & $8.65 \pm 1.53$ & $8.51 \pm 0.22$ & $\leq 4$ & $\leq 4$ & $\leq 4$ & $4.15 \pm 0.38$ \\
\hline Sn & $\leq 2$ & $\leq 2$ & $\leq 7$ & $\leq 7$ & $\leq 7$ & (3) \\
\hline Sb & $\leq 0.03$ & $\leq 0.08$ & $\leq 0.06$ & $\leq 0.02$ & $\leq 0.06$ & $(0.01)$ \\
\hline Cs & $\leq 0.004$ & $0.004-0.007$ & $\leq 0.02$ & $\leq 0.02$ & $\leq 0.02$ & 0.02 \\
\hline $\mathbf{B a}$ & $\leq 9$ & $\leq 5$ & $\leq 32$ & $\leq 32$ & $\leq 32$ & Not certified \\
\hline La & $\leq 0.02$ & $\leq 0.003$ & $\leq 0.5$ & $\leq 0.5$ & $\leq 0.5$ & 0.3 \\
\hline $\mathrm{Ce}$ & $\leq 0.07$ & $\leq 0.02$ & $0.21 \pm 0.03$ & $0.1 \overline{7} \pm 0.03$ & 0.19 & 0.4 \\
\hline Sm & $\leq 0.003$ & $\leq 0.002$ & $\leq 0.02$ & $\leq 0.02$ & $\leq 0.02$ & 0.06 \\
\hline Eu & $\leq 0.0009$ & $\leq 0.0006$ & $0.01 \overline{2} \pm 0.001$ & $0.01 \overline{3} \pm 0.001$ & 0.012 & 0.01 \\
\hline $\mathbf{T b}$ & $\leq 0.001$ & $\leq 0.001$ & $\leq 0.008$ & $\leq 0.007$ & $\leq 0.008$ & 0.007 \\
\hline Hf & $\leq 0.001$ & $\leq 0.001$ & $0.025 \pm 0.005$ & $0.032 \pm 0.004$ & 0.03 & 0.04 \\
\hline $\mathbf{T a}$ & $\leq 0.0007$ & $\leq 0.0005$ & $\leq 0.003$ & $\leq 0.003$ & $\leq 0.003$ & 0.003 \\
\hline Au & $\leq 0.05$ & $\leq 0.0002$ & $\leq 0.03$ & $\leq 0.04$ & $\leq 0.04$ & 0.01 \\
\hline Th & $\leq 0.002$ & $\leq 0.001$ & $0.035 \pm 0.006$ & $0.034 \pm 0.006$ & 0.035 & 0.04 \\
\hline $\mathbf{U}$ & $\leq 0.2$ & $\leq 0.004$ & $\leq 0.8$ & $\leq 0.8$ & $\leq 0.8$ & $0.13 \pm 0.01$ \\
\hline
\end{tabular}


Table B5: Results of INAA of control materials included with analyses of liver tissues. Values for SRM 1566a Oyster Tissue are expressed on a dry mass basis and Whale Liver Homogenate I are expressed on a wet mass basis. Uncertainty values represent the expanded uncertainties $(\mathrm{U} ; \mathrm{k}=2)$.

\begin{tabular}{|c|c|c|c|c|c|c|c|c|}
\hline Element & $\begin{array}{c}\text { Whale Liver } \\
\text { Homogenate I } \\
\text { Aliquot } 1 \\
\end{array}$ & $\begin{array}{c}\text { Whale Liver } \\
\text { Homogenate I } \\
\text { Aliquot } 2 \\
\end{array}$ & $\begin{array}{c}\text { Average } \\
\text { Value } \\
\end{array}$ & $\begin{array}{c}\text { Assigned } \\
\text { Values } \\
\end{array}$ & $\begin{array}{c}\text { SRM 1566a } \\
\text { Oyster Tissue } \\
\text { Aliquot } 1 \\
\end{array}$ & $\begin{array}{c}\text { SRM 1566a } \\
\text { Oyster Tissue } \\
\text { Aliquot } 2 \\
\end{array}$ & Average Value & Certified Values \\
\hline $\mathbf{N a}$ & 1205 & 1272 & $1239 \pm 31$ & $1260 \pm 30$ & $4220 \pm 20$ & -- & -- & $4170 \pm 130$ \\
\hline Mg & 135 & 130 & $133 \pm 10.5$ & $140 \pm 5$ & $1180 \pm 20$ & -- & -- & $1180 \pm 170$ \\
\hline $\mathrm{Cl}$ & 1594 & 1691 & $1594 \pm 79.3$ & $1730 \pm 40$ & $8120 \pm 270$ & -- & -- & $8290 \pm 140$ \\
\hline $\mathbf{K}$ & 2585 & 2748 & $2667 \pm 90$ & $2640 \pm 70$ & $8340 \pm 90$ & -- & -- & $7900 \pm 470$ \\
\hline $\mathbf{C a}$ & 39.7 & 55.6 & $48 \pm 10.3$ & $46 \pm 3$ & $2000 \pm 40$ & -- & -- & $1960 \pm 190$ \\
\hline $\mathbf{V}$ & $\leq 0.02$ & $\leq 0.02$ & $\leq 0.02$ & $\leq 0.03$ & $4.94 \pm 0.09$ & -- & -- & $4.68 \pm 0.15$ \\
\hline Mn & 2.84 & 2.99 & $2.92 \pm 0.06$ & $2.81 \pm 0.10$ & $12.3 \pm 1.0$ & -- & -- & $12.3 \pm 1.5$ \\
\hline $\mathrm{Cu}$ & 2.87 & 2.45 & $2.66 \pm 0.60$ & $2.96 \pm 0.55$ & $71 \pm 2$ & -- & -- & $66.3 \pm 4.3$ \\
\hline $\mathrm{Br}$ & 14.4 & 14.3 & $14.4 \pm 2.0$ & $13.7 \pm 0.6$ & $66 \pm 3$ & -- & -- & Not certified \\
\hline I & $\leq 3$ & $\leq 3.4$ & $\leq 3.4$ & $\leq 1$ & $\leq 9$ & -- & -- & $4.46 \pm 0.42$ \\
\hline Sc & $\leq 0.09$ & $\leq 0.09$ & $\leq 0.09$ & $\leq 0.08$ & 0.050 & 0.052 & $0.051 \pm 0.001$ & $(0.06)$ \\
\hline $\mathrm{Fe}$ & 394 & 425 & $410 \pm 20$ & $438 \pm 10$ & 528 & 529 & $528.5 \pm 12$ & $539 \pm 15$ \\
\hline Co & 0.012 & 0.013 & $0.013 \pm 0.001$ & $0.014 \pm 0.001$ & 0.46 & 0.56 & $0.51 \pm 0.08$ & $0.57 \pm 0.11$ \\
\hline $\mathbf{Z n}$ & 29.1 & 31.4 & $30.2 \pm 0.7$ & $32.2 \pm 0.7$ & 829 & 839 & $834 \pm 5$ & $11.1 \pm 1.0$ \\
\hline Mo & $\leq 0.41$ & $\leq 0.31$ & $\leq 0.4$ & $\leq 0.4$ & $\leq 1$ & nd & $\leq 1$ & Not certified \\
\hline Ag & 0.17 & 0.18 & $0.18 \pm 0.01$ & $0.181 \pm 0.005$ & 1.71 & 1.72 & $1.72 \pm 0.06$ & $1.68 \pm 0.15$ \\
\hline Cd & 8.44 & nd & $8.44 \pm 0.38$ & $8.51 \pm 0.22$ & 3.90 & 4.21 & $4.06 \pm 0.80$ & $4.15 \pm 0.38$ \\
\hline Sn & $\leq 2$ & $\leq 2$ & $\leq 2$ & $\leq 2$ & $\leq 8$ & $\leq 8$ & $\leq 8$ & (3) \\
\hline Sb & $\leq 0.02$ & $\leq \overline{0.02}$ & $\leq 0.02$ & $\leq \overline{0.08}$ & $\leq 0.02$ & $\leq 0.02$ & $\leq 0.02$ & $(0.01)$ \\
\hline Cs & 0.0056 & 00077 & $0.007 \pm 0.002$ & $0.004-0.007$ & $\leq 0.02$ & $\leq 0.02$ & $\leq 0.02$ & 0.02 \\
\hline $\mathbf{B a}$ & $\leq 8$ & $\leq 4$ & $\leq 8$ & $\leq 5$ & $\leq 15$ & $\leq 25$ & $\leq 25$ & Not certified \\
\hline La & $\leq 0.006$ & $\leq 0.003$ & $\leq 0.006$ & $\leq 0.003$ & 0.24 & 0.27 & $0.26 \pm 0.02$ & $(0.3)$ \\
\hline $\mathrm{Ce}$ & $\leq 0.0013$ & $\leq 0.0014$ & $\leq 0.0014$ & $\leq 0.02$ & 0.197 & 0.216 & $0.21 \pm 0.01$ & $(0.4)$ \\
\hline Sm & $\leq 0.001$ & $\leq 0.002$ & $\leq 0.002$ & $\leq 0.002$ & 0.055 & 0.050 & $0.053 \pm 0.004$ & $(0.06)$ \\
\hline Eu & $\leq 0.0001$ & $\leq 0.0001$ & $\leq 0.001$ & $\leq 0.0006$ & $\leq 0.01$ & $\leq 0.01$ & $\leq 0.01$ & $(0.01)$ \\
\hline $\mathbf{T b}$ & $\leq 0.001$ & $\leq 0.001$ & $\leq 0.001$ & $\leq 0.001$ & $\leq 0.008$ & $\leq 0.008$ & $\leq 0.008$ & $(0.007)$ \\
\hline Hf & $\leq 0.0001$ & $\leq 0.0001$ & $\leq 0.0001$ & $\leq 0.001$ & 0.023 & 0.033 & $0.03 \pm 0.01$ & $(0.040)$ \\
\hline $\mathbf{T a}$ & $\leq 0.0001$ & $\leq 0.0001$ & $\leq 0.0001$ & $\leq 0.0005$ & $\leq 0.001$ & $\leq 0.001$ & $\leq 0.001$ & $(0.003)$ \\
\hline Au & $\leq 0.003$ & $\leq 0.003$ & $\leq 0.003$ & $\leq 0.0002$ & $\leq 0.014$ & $\leq 0.014$ & $\leq 0.014$ & $(0.01)$ \\
\hline Th & $\leq 0.00015$ & $\leq 0.00016$ & $\leq 0.00016$ & $\leq 0.001$ & 0.035 & 0.040 & $0.038 \pm 0.003$ & $(0.04)$ \\
\hline $\mathbf{U}$ & $\leq 0.08$ & $\leq 0.05$ & $\leq 0.08$ & $\leq 0.004$ & 0.112 & 0.134 & $0.12 \pm 0.02$ & $0.13 \pm 0.01$ \\
\hline
\end{tabular}


Table B6: Results of ICP-MS of Whale Liver Homogenate I expressed in $\mathrm{mg} / \mathrm{kg}$ of wet mass. Uncertainties represent the expanded uncertainties ( $\mathrm{U} ; \mathrm{k}=2)$.

\begin{tabular}{ccc}
\hline Element & ICP-MS Value (mg/kg) & Assigned Values (Wise et al., 1993) \\
\hline $\mathbf{M n}$ & $3.9 \pm 0.7$ & $2.81 \pm 0.08$ \\
$\mathbf{C u}$ & $3.88 \pm 0.59$ & $2.96 \pm 0.20$ \\
$\mathbf{Z n}$ & $36.4 \pm 7.9$ & $32.2 \pm 0.7$ \\
$\mathbf{A g}$ & $0.22 \pm 0.04$ & $0.181 \pm 0.005$ \\
$\mathbf{C d}$ & $8.91 \pm 1.10$ & $8.51 \pm 0.22$ \\
$\mathbf{S n}$ & $0.19 \pm 0.04$ & $\leq 2$ \\
$\mathbf{H g}$ & $27.0 \pm 3.5$ & $28.2 \pm 1.1$ \\
\hline
\end{tabular}


Table B7: Linear correlation matrix for rough-toothed dolphin age, length, and hepatic element concentrations.

\begin{tabular}{|c|c|c|c|c|c|c|c|c|c|c|c|c|c|c|c|}
\hline & age & length & $\mathrm{Na}$ & $\mathrm{Cl}$ & $\mathrm{K}$ & $\mathrm{Cu}$ & $\mathrm{Fe}$ & $\mathrm{Co}$ & $\mathrm{Zn}$ & $\mathrm{Se}$ & $\mathrm{Rb}$ & $\mathrm{Ag}$ & $\mathrm{Cd}(\mathrm{ICP})$ & $\mathrm{Hg}$ (ICP) & $\mathrm{Sn}$ (ICP) \\
\hline age & 1.00 & 0.74 & 0.30 & 0.17 & -0.50 & 0.57 & -0.28 & 0.09 & -0.54 & $\mathbf{0 . 9 5}$ & -0.49 & $\mathbf{0 . 9 0}$ & 0.53 & $\mathbf{0 . 9 6}$ & $\mathbf{0 . 9 5}$ \\
\hline length & 0.74 & 1.00 & 0.52 & 0.51 & -0.72 & 0.59 & -0.57 & 0.35 & -0.54 & 0.77 & -0.62 & $\mathbf{0 . 8 5}$ & 0.69 & $\mathbf{0 . 7 8}$ & $\mathbf{0 . 8 4}$ \\
\hline $\mathrm{Na}$ & 0.30 & 0.52 & 1.00 & $\mathbf{0 . 8 4}$ & $\mathbf{- 0 . 8 4}$ & -0.03 & -0.75 & 0.41 & -0.04 & 0.07 & $\mathbf{- 0 . 8 8}$ & 0.29 & 0.52 & 0.07 & 0.14 \\
\hline $\mathrm{Cl}$ & 0.17 & 0.51 & $\mathbf{0 . 8 4}$ & 1.00 & -0.68 & -0.18 & -0.74 & 0.49 & 0.07 & 0.05 & -0.69 & 0.14 & 0.38 & 0.04 & 0.12 \\
\hline $\mathrm{K}$ & -0.50 & -0.72 & $\mathbf{- 0 . 8 4}$ & -0.68 & 1.00 & -0.30 & 0.61 & -0.31 & 0.23 & -0.31 & $\mathbf{0 . 9 0}$ & -0.55 & -0.68 & -0.32 & -0.34 \\
\hline $\mathrm{Cu}$ & 0.57 & 0.59 & -0.03 & -0.18 & -0.30 & 1.00 & -0.05 & -0.11 & -0.56 & 0.64 & -0.16 & $\mathbf{0 . 8 0}$ & 0.62 & 0.65 & 0.62 \\
\hline $\mathrm{Fe}$ & -0.28 & -0.57 & -0.75 & -0.74 & 0.61 & -0.05 & 1.00 & -0.70 & 0.08 & -0.12 & 0.71 & -0.36 & -0.62 & -0.13 & -0.32 \\
\hline $\mathrm{Co}$ & 0.09 & 0.35 & 0.41 & 0.49 & -0.31 & -0.11 & -0.70 & 1.00 & -0.17 & 0.04 & -0.33 & 0.24 & 0.67 & 0.04 & 0.27 \\
\hline $\mathrm{Zn}$ & -0.54 & -0.54 & -0.04 & 0.07 & 0.23 & -0.56 & 0.08 & -0.17 & 1.00 & -0.44 & 0.01 & -0.53 & -0.58 & -0.46 & -0.57 \\
\hline $\mathrm{Se}$ & $\mathbf{0 . 9 5}$ & 0.77 & 0.07 & 0.05 & -0.31 & 0.64 & -0.12 & 0.04 & -0.44 & 1.00 & -0.23 & $\mathbf{0 . 9 0}$ & 0.40 & $\mathbf{1 . 0 0}$ & $\mathbf{0 . 9 5}$ \\
\hline $\mathrm{Rb}$ & -0.49 & -0.62 & $\mathbf{- 0 . 8 8}$ & -0.69 & $\mathbf{0 . 9 0}$ & -0.16 & 0.71 & -0.33 & 0.01 & -0.23 & 1.00 & -0.47 & -0.56 & -0.23 & -0.28 \\
\hline $\mathrm{Ag}$ & $\mathbf{0 . 9 0}$ & $\mathbf{0 . 8 5}$ & 0.29 & 0.14 & -0.55 & $\mathbf{0 . 8 0}$ & -0.36 & 0.24 & -0.53 & $\mathbf{0 . 9 0}$ & -0.47 & 1.00 & 0.67 & $\mathbf{0 . 9 0}$ & $\mathbf{0 . 9 1}$ \\
\hline $\mathrm{Cd}$ (ICP) & 0.53 & 0.69 & 0.52 & 0.38 & -0.68 & 0.62 & -0.62 & 0.67 & -0.58 & 0.40 & -0.56 & 0.67 & 1.00 & 0.40 & 0.54 \\
\hline $\mathrm{Hg}$ (ICP) & $\mathbf{0 . 9 6}$ & $\mathbf{0 . 7 8}$ & 0.07 & 0.04 & -0.32 & 0.65 & -0.13 & 0.04 & -0.46 & $\mathbf{1 . 0 0}$ & -0.23 & $\mathbf{0 . 9 0}$ & 0.40 & 1.00 & $\mathbf{0 . 9 5}$ \\
\hline $\mathrm{Sn}$ (ICP) & $\mathbf{0 . 9 5}$ & $\mathbf{0 . 8 4}$ & 0.14 & 0.12 & -0.34 & 0.62 & -0.32 & 0.27 & -0.57 & $\mathbf{0 . 9 5}$ & -0.28 & $\mathbf{0 . 9 1}$ & 0.54 & $\mathbf{0 . 9 5}$ & 1.00 \\
\hline
\end{tabular}


Table B8: Linear correlation matrix for rough-toothed dolphin age, length, and renal element concentrations.

\begin{tabular}{|c|c|c|c|c|c|c|c|c|c|c|c|c|c|c|c|c|c|}
\hline & age & length & $\mathrm{Na}$ & $\mathrm{Cl}$ & $\mathrm{K}$ & $\mathrm{Mn}$ & $\mathrm{Br}$ & $\mathrm{Fe}$ & $\mathrm{Co}$ & $\mathrm{Zn}$ & As & $\mathrm{Se}$ & $\mathrm{Rb}$ & $\mathrm{Ag}$ & $\mathrm{Cd}(\mathrm{ICP})$ & $\mathrm{Hg}$ (ICP) & Sn (ICP) \\
\hline age & 1.00 & 0.74 & -0.66 & -0.83 & -0.93 & -0.80 & -0.62 & -0.31 & -0.33 & -0.88 & 0.75 & 0.77 & -0.83 & -0.36 & -0.17 & 0.92 & 0.47 \\
\hline length & 0.74 & 1.00 & -0.18 & -0.58 & -0.83 & -0.60 & -0.60 & 0.04 & -0.28 & -0.65 & 0.85 & 0.80 & -0.66 & -0.02 & 0.15 & .81 & 0.46 \\
\hline $\mathrm{Na}$ & -0.66 & -0.18 & 1.00 & 0.67 & 0.34 & 0.40 & 0.58 & 0.24 & -0.23 & 0.41 & -0.28 & -0.20 & 0.32 & 0.27 & -0.06 & -0.30 & -0.45 \\
\hline $\mathrm{Cl}$ & -0.83 & -0.58 & 0.67 & 1.00 & 0.67 & 0.57 & 0.72 & 0.15 & -0.09 & 0.50 & -0.61 & -0.71 & 0.60 & 0.23 & -0.04 & -0.80 & -0.39 \\
\hline $\mathrm{K}$ & -0.93 & -0.83 & 0.34 & 0.67 & 1.00 & 0.78 & 0.66 & 0.36 & 0.27 & 0.83 & -0.72 & -0.59 & 0.88 & 0.21 & 0.15 & -0.76 & -0.39 \\
\hline $\mathrm{Mn}$ & -0.80 & -0.60 & 0.40 & 0.57 & 0.78 & 1.00 & 0.63 & 0.28 & 0.42 & 0.83 & -0.43 & -0.39 & 0.80 & -0.05 & 0.32 & -0.63 & -0.28 \\
\hline $\mathrm{Br}$ & -0.62 & -0.60 & 0.58 & 0.72 & 0.66 & 0.63 & 1.00 & 0.29 & 0.01 & 0.47 & -0.63 & -0.44 & 0.57 & -0.25 & -0.26 & -0.46 & -0.56 \\
\hline $\mathrm{Fe}$ & -0.31 & 0.04 & 0.24 & 0.15 & 0.36 & 0.28 & 0.29 & 1.00 & -0.13 & 0.19 & -0.83 & 0.10 & 0.35 & 0.51 & 0.01 & 0.06 & -0.34 \\
\hline $\mathrm{Co}$ & -0.33 & -0.28 & -0.23 & -0.09 & 0.27 & 0.42 & 0.01 & -0.13 & 1.00 & 0.39 & -0.37 & 0.02 & 0.51 & 0.38 & .43 & -0.16 & -0.08 \\
\hline $\mathrm{Zn}$ & -0.88 & -0.65 & 0.41 & 0.50 & 0.83 & 0.83 & 0.47 & 0.19 & 0.39 & 1.00 & -0.72 & -0.37 & 0.76 & 0.28 & 0.43 & -0.65 & -0.32 \\
\hline As $(n=5)$ & 0.75 & 0.85 & -0.28 & -0.61 & -0.72 & -0.43 & -0.63 & -0.83 & -0.37 & -0.72 & 1.00 & 0.89 & -0.59 & -0.30 & -0.38 & 0.63 & 0.45 \\
\hline $\mathrm{Se}$ & 0.77 & 0.80 & -0.20 & -0.71 & -0.59 & -0.39 & -0.44 & 0.10 & 0.02 & -0.37 & 0.89 & 1.00 & -0.40 & 0.05 & 0.28 & 0.86 & 0.24 \\
\hline $\mathrm{Rb}$ & -0.83 & -0.66 & 0.32 & 0.60 & 0.88 & 0.80 & 0.57 & 0.35 & 0.51 & 0.76 & -0.59 & -0.40 & 1.00 & 0.41 & 0.25 & -0.64 & -0.31 \\
\hline $\operatorname{Ag}(n=6)$ & -0.36 & -0.02 & 0.27 & 0.23 & 0.21 & -0.05 & -0.25 & 0.51 & 0.38 & 0.28 & -0.30 & 0.05 & 0.41 & 1.00 & 0.44 & -0.37 & -0.39 \\
\hline $\mathrm{Cd}(\mathrm{ICP})$ & -0.17 & 0.15 & -0.06 & -0.04 & 0.15 & 0.32 & -0.26 & 0.01 & 0.43 & 0.43 & -0.38 & 0.28 & 0.25 & 0.44 & 1.00 & -0.11 & 0.25 \\
\hline $\mathrm{Hg}(\mathrm{ICP})$ & 0.92 & 0.81 & -0.30 & -0.80 & -0.77 & -0.63 & -0.45 & 0.06 & -0.17 & -0.65 & 0.62 & 0.86 & -0.64 & -0.38 & -0.11 & 1.00 & 0.36 \\
\hline $\mathrm{Sn}(\mathrm{ICP})$ & 0.47 & 0.46 & -0.45 & -0.39 & -0.39 & -0.28 & -0.56 & -0.34 & -0.08 & -0.32 & 0.45 & 0.24 & -0.31 & -0.39 & 0.25 & 0.36 & 1.00 \\
\hline
\end{tabular}

